\title{
INVESTIGAÇÃO DE POLIMORFISMOS NOS GENES DOS FATORES MIOGÊNICOS E MIOSTATINA COMO MARCADORES MOLECULARES PARA CARACTERÍSTICAS QUANTITATIVAS EM Gallus gallus
}

\section{CARLA DOS ANJOS DE SOUZA}

\author{
Dissertação apresentada à Escola Superior de \\ Agricultura "Luiz de Queiroz", Universidade de \\ São Paulo, para obtenção do título de Mestre em \\ Agronomia, Área de Concentração: Ciência \\ Animal e Pastagens
}

P I R A CI C A B A

Estado de São Paulo - Brasil

Dezembro - 2004 


\section{INVESTIGAÇÃO DE POLIMORFISMOS NOS GENES DOS FATORES MIOGÊNICOS E MIOSTATINA COMO MARCADORES MOLECULARES PARA CARACTERÍSTICAS QUANTITATIVAS EM Gallus gallus}

\section{CARLA DOS ANJOS DE SOUZA}

Zootecnista

Orientador: Prof. Dr. LUIZ LEHMANN COUTINHO

Dissertação apresentada à Escola Superior de Agricultura "Luiz de Queiroz", Universidade de São Paulo, para obtenção do título de Mestre em Agronomia, Área de Concentração: Ciência Animal e Pastagens

P I R A C I C A B A

Estado de São Paulo - Brasil

Dezembro - 2004 
Dados Internacionais de Catalogação na Publicação (CIP) DIVISÃO DE BIBLIOTECA E DOCUMENTAÇÃO - ESALQ/USP

Souza, Carla dos Anjos de

Investigação de polimorfismo nos genes dos fatores miogênicos e miostatina como marcadores moleculares para características quantitativas em Gallus gallus / Carla do Anjos de Souza. - - Piracicaba, 2004.

108 p. : il.

Dissertação (Mestrado) - - Escola Superior de Agricultura Luiz de Queiroz, 2004. Bibliografia.

1. Avicultura 2. Biotecnologia 3. Crescimento e desenvolvimento 4. Genes 5. Marcador molecular 6. Polimorfismo I. Título

CDD 636.5

"Permitida a cópia total ou parcial deste documento, desde que citada a fonte - $\mathrm{O}$ autor" 


\section{DEDICO}

Aos meus amados pais Raimundo e Neide e à minha irmã Claudia.

Com vocês dividi alegrias, aflições e sonhos. Alguns destes sonhos com o tempo se vão, outros porém tornam-se realidade. A vocês toda minha conquista, por vocês toda fé na vida, para vocês todo meu amor.

\section{OFEREÇO}

Aos meus avós Hildebrando e Juracy (in memorian) pelo amor e educação 


\section{AGRADECIMENTOS}

A todos que colaboraram direta ou indiretamente para a realização desse trabalho. Em especial:

Ao Prof. Dr. Luiz Lehmann Coutinho pela orientação, apoio e valiosos conhecimentos durante os anos de mestrado.

A pesquisadora Dra. Mônica Ledur pela orientação e pela oportunidade de realizar este trabalho.

Ao Prof. Dr. Irineu Umberto Packer pelos ensinamentos e contribuição ao meu desenvolvimento profissional.

Aos pesquisadores Lúcia Elvira Álvares, Amauri Wenceslau e Claudia Cristina Paro Paz pela troca de experiências, discussões e sugestões.

Aos colegas do Labotratório de Biotecnologia que de alguma forma contribuíram para a realização deste trabalho.

Aos meus grandes amigos Valéria, Ciane e Flávio que apesar da distancia sempre estiveram presentes.

Às amigas Clarissa (Clareca), Ana Paula (Flipper) e Helena pelo apoio em todos os momentos, pelo companheirismo e amizade. 
Às amigas Priscilla (Inguiço), Isabel (Bel), Adriana e Aline, minha família "emprestada", por todos os momentos compartifhados, principalmente pela paciência e amizade.

Aos amigos Marcus Vinícius (Urrahh!!!), Anderson (Folha), Daniel (Bibo), Ro6son Barizon (Zuza), Adriano (Min), Anderson (Lange) e Élio pelo companheirismo e momentos de descontração.

Aos amigos da Vila Estudaltil da ESALQ Érikga, Júlio, Wirifran e Cláudio pelos momentos compartilhados.

A Escola Superior de Agricultura Luiz de Queiroz pela oportunidade de realizar o curso.

À FAPESP pela concessão da bolsa de estudo.

$\mathcal{A}$ todos que estiveram presentes na minha vida e durante a realização deste trabalho, $o$ meu muito obrigada. 
"Se não houver frutos

Valeu a beleza das flores

Se não houver flores

Valeu a sombra das folhas

Se não houver folhas

Valeu a intenção da semente"

Henfil 


\section{SUMÁRIO}

Página

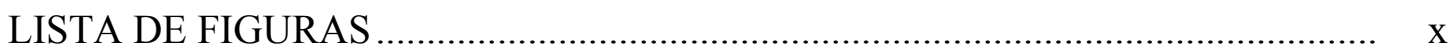

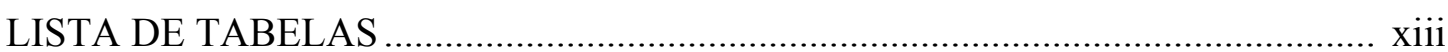

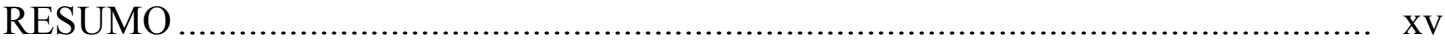

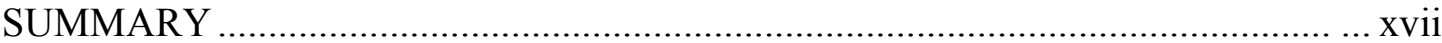

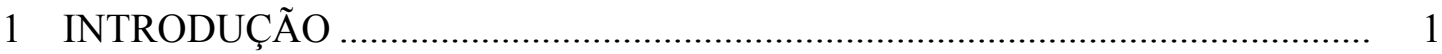

2 REVISÃO DE LITERATURA ….................................................................... 4

2.1 Biotecnologia na avicultura.......................................................................... 4

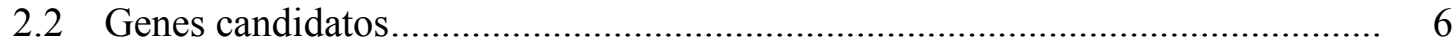

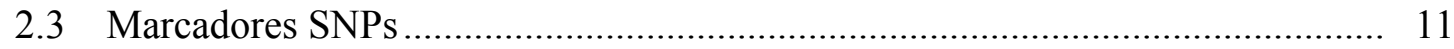

2.4 Formação da fibra muscular...................................................................... 12

2.5 Origem Embriológica da Musculatura Esquelética .......................................... 13

2.6 Fatores regulatórios da miogênese ............................................................... 16

2.6.1 Propriedades estruturais das proteínas MRF .................................................. 17

2.6.2 Expressão espacial e temporal dos fatores miogênicos.................................... 19

2.6.3 Papel funcional dos fatores miogênicos na formação da musculatura

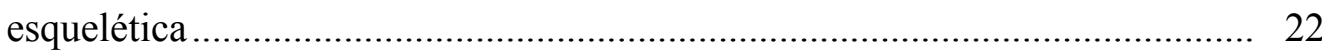

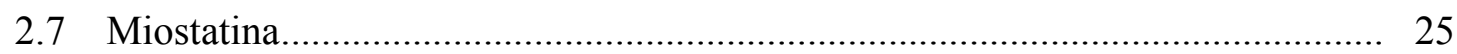

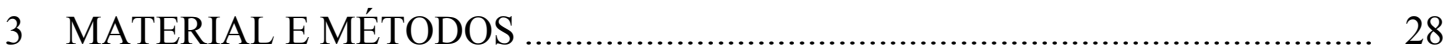

3.1 Formação da população referência.................................................................... 28

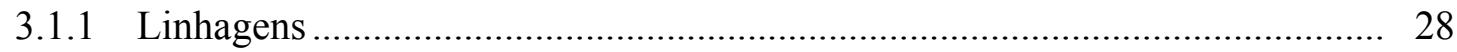

3.1.2 Formação da geração F1 e F2 ................................................................... 29 


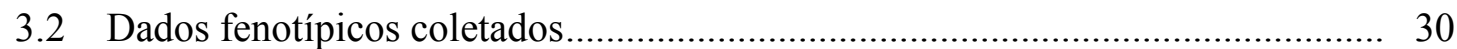

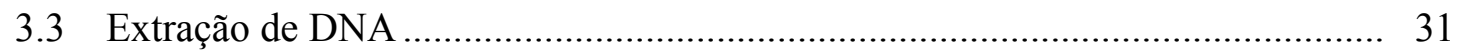

3.4 Leitura no espectrofotômetro ................................................................ 31

3.5 Detecção de polimorfismos............................................................................. 31

3.5.1 Preparação dos pools de DNA ................................................................ 31

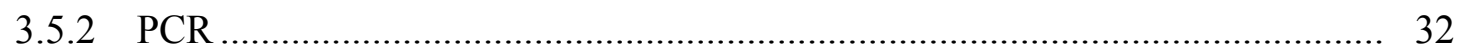

3.5.3 Clonagem e seqüenciamento dos produtos de PCR ...................................... 33

3.5.4 Análise das seqüências........................................................................ 33

3.6 Escolha dos polimorfismos e desenho de primers para genotipagem................. 34

3.7 Otimização da PCR …….......................................................................... 35

3.8 Purificação pré-seqüenciamento dos produtos da PCR ..................................... 38

3.9 Seqüenciamento dos produtos de PCR …...................................................... 38

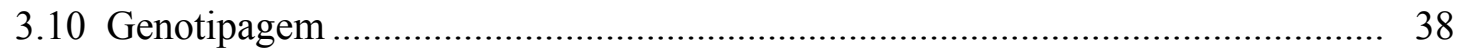

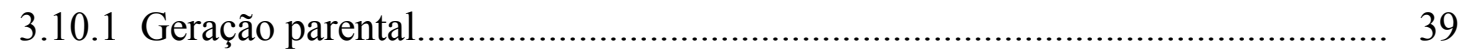

3.10.2 Genotipagem seletiva da geração F2 …….................................................. 39

3.10.3 Genotipagem dos indivíduos F2 das famílias informativas ........................... 40

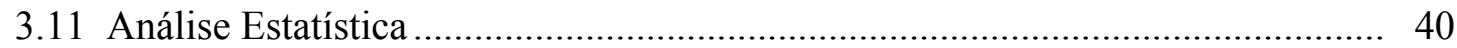

3.11.1 Teste $\chi^{2}$ (Qui-quadrado) ....................................................................... 40

3.11.2 Análise de Variância ................................................................................. 41

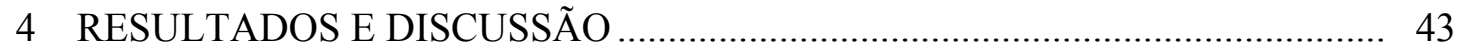

4.1 Detecção de polimorfismos............................................................................ 43

4.2 Validação de polimorfismos .................................................................. 50

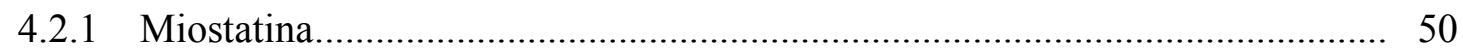

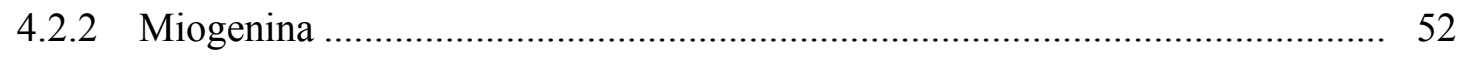

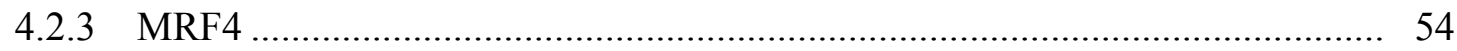

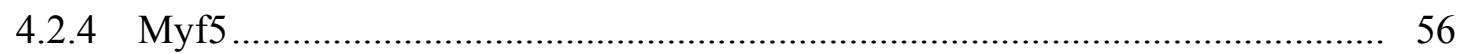

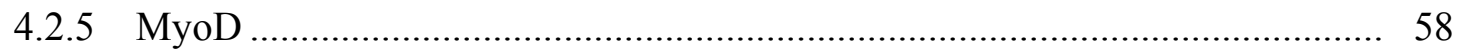

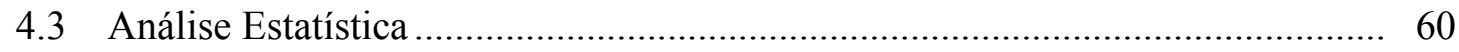

4.3.1 Seleção dos animais para genotipagem seletiva.............................................. 61

4.3.2 Test $\chi 2$ da genotipagem seletiva ................................................................ 63 
4.3.3 Genotipagem dos indivíduos F2 das famílias informativas. 63

4.3.4 Análise de variância ................................................................................ 66

4.3.5 Miostatina e o mapeamento de QTLs no cromossomo 7 ............................... 73

4.3.6 MyoD e o mapeamento de QTLs no cromossomo 5..................................... 74

4.3.7 Genotipagem seletiva na análise de genes candidatos ................................ 74

4.3.8 Efeito da miogenina sobre as características de desempenho e carcaça ........... 75

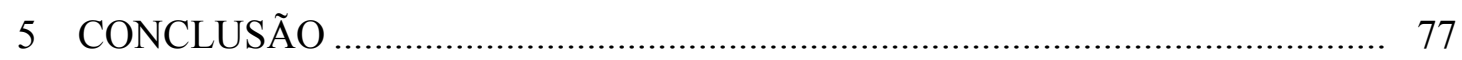

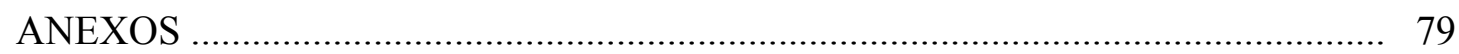

REFERÊNCIAS BIBLIOGRÁFICAS ............................................................... 95 


\section{LISTA DE FIGURAS}

Página

1 Maturação do somito epitelial. A figura ilustra a subdivisão do somito em compartimentos: o esclerótomo, o dermomiótomo e seus subdomínios e o miótomo, originado pela migração das células do dermomiótomo epaxial e hipaxial, durante e após o processo de brotamento da placa segmentar.

2 Alinhamento das seqüências traduzidas dos genes da família MyoD de Gallus gallus, realizado pelo ClustalW multiple sequence alignment (www.ebi.ac.uk/clustalw). Vermelho - resíduos hidrofóbicos e aromáticos; azul - resíduos negativamente carregados; magenta - resíduos positivamente carregados; verde - outros resíduos polares. (*) - Os resíduos nessa coluna são idênticos em todas as seqüências do alinhamento; (:) - substituições conservadas identificadas por letras da mesma cor; (.) - substituições semiconservadas

3 Expressão temporal dos fatores miogênicos durante o desenvolvimento da musculatura esquelética. MyoD e Myf5 atuam na determinação de mioblastos, enquanto que a miogenina, e o MRF4 estão envolvidos no programa de diferenciação terminal das células musculares (Weintraub et al., 1991).

4 Seqüência do contig 1 da miostatina com a localização dos polimorfismos detectados, segundo a numeração disponível no NCBI (acesso AF346599).

5 Seqüência do contig 2 da miostatina com a localização dos polimorfismos detectados (NCBI, acesso AF346599) 
6 Contigs formados pela remontagem das seqüências dos contigs 1 e 2 da miogenina.

7 Polimorfismos detectados nos contigs 1 e 2 referentes à extremidade 5'. A região CDS foi localizada pelo alinhamento dos contigs com a seqüência disponível sob número de acesso D90157 no NCBI, realizada pelo programa Vector NTI.

8 Polimorfismos detectados nos contigs 3 e 4 referentes à extremidade 3'. A região CDS foi localizada pelo alinhamento dos contigs com a seqüência disponível sob acesso D90157 no NCBI, realizada pelo programa Vector NTI.

9 Seqüência do único contig do gene Myf5 com a localização dos polimorfismos detectados (NCBI, acesso X73250).

10 Gene MyoD de Gallus gallus com a localização dos primers e do polimorfismo caracterizado pela deleção de 13 pares de base no intron 2 .

11 Localização do sítio polimórfico 4938 da miostatina: Substituição A => G, presente em parentais da linhagem CC.

12 Padrão dos cromatogramas dos possíveis genótipos no loco A4938G da miostatina, obtidos no seqüenciamento dos produtos de PCR

13 Polimorfismos detectados na genotipagem por seqüenciamento da miogenina, na geração parental: 1 - C => T, polimorfismo miog_10 ou nucleotídeo 455 (acesso D90157, NCBI); $2-\mathrm{T}=>\mathrm{C}$, polimorfismo miog_13; $3-\mathrm{C}=>\mathrm{T}$, $\operatorname{miog} \_16 ; 4-\mathrm{C}=\mathrm{T}, \operatorname{miog} \_16 ; 5-$ Deleção [AATCACA] e [A], polimorfismo miog_17; 6 - Deleção [AATCACA] e [A], polimorfismo miog_17. 
14 Ilustração do fragmento clonado do gene MRF4 e localização dos primers testados. As regiões CDS foram localizadas pelo alinhamento dos contigs com a seqüência acessada pelo ID - D10599 no NCBI, realizado pelo programa Vector NTI.

15 Gene Myf5 (GenBank, ID: X73250), contendo a localização dos primers testados

16 Produto de PCR seqüenciado do gene MyoD. A deleção de 13 pares de base está destacada em vermelho e a região microssatélite $[\mathrm{AGC}]$ em azul. 


\section{LISTA DE TABELAS}

Página

1 Resultados obtidos pela análise de genes candidatos relacionados à caracteres de produção.

2 Resultados obtidos pela análise de genes candidatos envolvidos nos mecanismos imunológicos relacionados à resistência a inoculação de Salmonella enteritidis 10

3 Estrutura populacional do cruzamento TC 30

4 Seqüência dos primers utilizados nas PCRs e tamanho dos produtos resultantes da amplificação.

5 Seqüência dos primers desenhados e testados para a genotipagem. 35

6 Programa utilizado nos termocicladores para otimização da PCR ....................... 36

7 Conteúdo dos tampões 5X do PCR Optimizer Kit (Invitrogen)........................ 37

8 Número de contigs, reads e SNPs identificados em clones dos genes da miostatina, miogenina, MRF4 e Myf5

9 Pares de primers testados na otimização de PCR do gene MRF4 para genotipagem.

10 Pares de primers testados na otimização de PCR do gene Myf5 para genotipagem.

11 Genes e respectivos loco selecionados para a etapa de genotipagem. 
12 Correlações fenotípicas entre PV42 e características de desempenho de 2063 aves da geração F2 do cruzamento TC.

13 Correlações fenotípicas entre PV42 e caractrerísticas de carcaça de 2063 aves da geração F2 do cruzamento TC

14 Freqüências alélicas e probabilidades do teste qui-quadrado para cada loco genotipado

15 Média, desvio padrão (DP) e coeficiente de variação (CV) dos 96 animais das famílias informativas.

16 Média, desvio padrão (DP) e coeficiente de variação (CV) dos 96 animais por família

17 Freqüência de genótipos na amostra para um total de 86 observações válidas para os genes da miostatina, miogenina e MyoD.

18 Valores de probabilidade do teste $\mathrm{F}$, coeficiente de variação (CV), coeficiente de determinação $\left(\mathrm{R}^{2}\right)$ de acordo com o modelo de um único gene para o loco A4938G do gene da miostatina.

19 Valores de probabilidade do teste F, coeficiente de variação (CV), coeficiente de determinação $\left(\mathrm{R}^{2}\right)$ de acordo com o modelo de um único gene para o loco D6619-6631 do gene MyoD

20 Valores de probabilidade do teste F, coeficiente de variação (CV), coeficiente de determinação $\left(\mathrm{R}^{2}\right)$ de acordo com o modelo de um único gene para o loco $\mathrm{T} 455 \mathrm{C}$ do gene da miogenina.

21 Valores de probabilidade do teste $\mathrm{F}$, coeficiente de variação (CV) e coeficiente de determinação $\left(\mathrm{R}^{2}\right)$ de acordo com o modelo multigênico 


\section{INVESTIGAÇÃO DE POLIMORFISMOS NOS GENES DOS FATORES MIOGÊNICOS E MIOSTATINA COMO MARCADORES MOLECULARES PARA CARACTERÍSTICAS QUANTITATIVAS EM Gallus gallus}

Autor: CARLA DOS ANJOS DE SOUZA

Orientador: Prof. Dr. LUIZ LEHMANN COUTINHO

\section{RESUMO}

O presente trabalho teve como objetivo identificar polimorfismos em cinco genes candidatos (MyoD, Myf5, miogenina, MRF4 e miostatina) que atuam no desenvolvimento muscular de galinhas, e avaliar os efeitos de suas variantes alélicas sobre características quantitativas de crescimento e desenvolvimento muscular. Os genes MyoD e Myf5 são essenciais para a determinação da linhagem miogênica de células precursoras das fibras musculares na etapa inicial da miogênese, enquanto que a miogenina e MRF4 são requeridos na diferenciação final destas células. A miostatina por sua vez, atua como um potente regulador negativo do crescimento muscular esquelético durante a miogênese, persistindo por toda a fase adulta. Os produtos amplificados dos cinco genes foram clonados e seqüenciados a partir de pools de DNA dos parentais de duas linhagens divergentes desenvolvidas pela Embrapa - Suínos e Aves, uma de corte (TT) e outra de postura (CC). Os polimorfismos identificados foram validados e genotipados em uma população experimental F2, originada do cruzamento entre machos da linhagem TT e fêmeas da linhagem CC. Para avaliação dos efeitos dos polimorfismos sobre características quantitativas foram genotipados os genes da 
miostatina, miogenina e MyoD. Os polimorfismos dos genes da miostatina e MyoD não apresentaram efeito sobre nenhuma das características avaliadas. Dentre os sítios polimórficos detectados no gene da miogenina, um identificado como T455C apresentou associação estatisticamente significativa com as características: peso vivo ao 42 dias $(\mathrm{P}=0,0263)$, ganho de peso do nascimento aos 42 dias de idade $(\mathrm{P}=0,0291)$, ganho de peso dos 35 aos 42 dias de idade $(\mathrm{P}=0,0368)$, peso da carcaça $(\mathrm{P}=0,0245)$, peso das asas $(\mathrm{P}=0,0099)$ e da carcaça residual $(\mathrm{P}=0,0056)$, peso da gordura abdominal $(\mathrm{P}=0,0320)$, do fígado $(\mathrm{P}=0,0373)$ e do pulmão $(\mathrm{P}=0,0262)$. Novas investigações poderão ser feitas no intuito de validar este polimorfismo como possível marcador genético para seleção de aves com maior capacidade de desenvolvimento muscular. Embora inúmeros polimorfismos tenham sido detectados nos genes Myf5 e MRF4, não foi possível estabelecer condições ideais para realização da genotipagem destes genes. 


\title{
INVESTIGATION OF POLYMORPHISMS OF MYOGENIC FACTORS AND MYOSTATIN GENES AS MOLECULAR MARKERS FOR QUANTITATIVE TRAITS IN Gallus gallus
}

\author{
Author: CARLA DOS ANJOS DE SOUZA \\ Adviser: Prof. Dr. LUIZ LEHMANN COUTINHO
}

\section{SUMMARY}

The aim of this work was to identify polymorphisms in five candidate genes (MyoD, Myf5, Myogenin, MRF4 and Myostatin) which act in chicken muscle development and evaluate the effects of its allelic variants on growth and muscle development quantitative traits. MyoD and Myf5 are essential for the determination of the myogenic lineage of muscle precursor cells in early stages of myogenesis, whereas myogenin and MRF4 are required for the final differentiation of these cells. Myostatin acts as a potent negative regulator of skeletal muscle growth during myogenesis and continues to be expressed in adult animals. PCR products of these five genes were cloned and sequenced from DNA pools of parental individuals from two distinct lineages developed by Embrapa - Suínos e Aves, a broiler sire line (TT) and a layer line (CC). The polymorphisms identified were validated and genotyped in a F2 experimental population originated from a crossing of TT line sires ands CC line dams. Polymorphisms of Myostatin, Myogenin and MyoD genes were genotyped to evaluate their effects on quantitative traits. The effects of Myostatin and MyoD polymorphisms were not significant on any traits. Among the polymorphic sites detected in the 
myogenin gene one, identifyed as $\mathrm{T} 455 \mathrm{C}$, was significantly associated with the following traits: body weight at 42 days of age $(\mathrm{P}=0,0263)$, body weight gain between birth and 42 days of age $(\mathrm{P}=0,0291)$, body weight gain between 35 and 42 days of age $(\mathrm{P}=0,0368)$, carcass weight $(\mathrm{P}=0,0245)$, weight of drums $(\mathrm{P}=0,0099)$, residual carcass $(\mathrm{P}=0,0056)$, abdominal fat $(\mathrm{P}=0,0320)$, liver $(\mathrm{P}=0,0373)$ and lungs $(\mathrm{P}=$ 0,0262). New investigations should be conducted to validate this polymorphism as a possible genetic marker for selection of chickens with increased muscle development potential. Although many polymorphisms were detected in Myf5 and MRF4 genes, it was not possible to establish ideal conditions for their genotyping. 


\section{INTRODUÇÃO}

A avicultura brasileira é uma das mais competitivas no comércio mundial, superando em vários aspectos países cuja produção é subsidiada pelo governo local, segundo o último relatório publicado pela Associação Brasileira de Produtores e Exportadores de Frango (ABEF, 2003). Atualmente o Brasil é o segundo maior produtor e exportador mundial de frangos em volume, e o primeiro exportador mundial em receita cambial. Poucos produtos na pauta de exportação brasileira apresentam desempenhos tão significativos, sendo este o terceiro maior produto de exportação do agronegócio brasileiro. Este resultado se deve à agressividade comercial da avicultura de exportação do Brasil, que oferece o menor custo de produção do mundo, sendo o mais eficiente produtor mundial segundo a IFC (International Finance Corporation) (ABEF, 2003). Dentre as principais vantagens competitivas da avicultura brasileira, está o desempenho dos produtores e da indústria, que têm recebido contribuições relevantes dos programas de melhoramento genético, os quais tem alcançado com sucesso tanto a demanda do mercado quanto da indústria. Entretanto, para que o nível de competitividade seja mantido no mercado, será imprescindível a incorporação de novas técnicas como ferramentas nos programas tradicionais de melhoramento genético para que maiores progressos sejam obtidos.

Durante as últimas décadas, os programas de seleção na avicultura, tanto de corte quanto de postura, apresentaram um progresso espetacular: a produção de ovos (número de ovos/galinha/ano) foi triplicada e a taxa de crescimento em aves de corte para alcançar 1,5 $\mathrm{kg}$ de peso vivo, foi quadruplicada durante este período (Burt, 2002). Entretanto, este progresso genético possui limites e acredita-se que sejam alcançados nos próximos 20 anos (Burt, 2002). Sendo assim, a indústria avícola deverá se adaptar 
às novas demandas do mercado consumidor e dos produtores, buscando oferecer produtos de melhor qualidade bem como a reduzir os custos de produção (Burt, 2002).

Dentro deste contexto, a pesquisa genômica na avicultura tem sido alvo de estudos intensos, uma vez que possibilita a identificação de marcadores genéticos distribuídos por todo genoma, os quais podem ou não estar envolvidos na expressão de características de interesse econômico (Burt, 2002). Uma das principais metas tem sido a identificação de locos que controlam características quantitativas, sendo a análise de genes candidatos uma das abordagens mais utilizadas para este fim (Rothschild \& Soller,1999).

Atualmente pode-se encontrar na literatura uma série de estudos realizados com aves, voltados para a identificação de marcadores em genes candidatos. Nos genes GH, GHR, IGF, foram identificados marcadores associados à características de produção (Kuhlein et al.1997; Feng et al., 1997; Nagaraja et al., 2000; Amills et al., 2003); nos genes GNRHR e NPY, associados a características reprodutivas (Dunn et al., 2004); e em uma série de genes envolvidos em mecanismos de resistência a Salmonella enteritidis (Malek \& Lamont, 2003; Kramer et al., 2003). Tendo em vista que o principal produto final na produção de frangos de corte é o tecido muscular, o número limitado de resultados na linha de pesquisa de marcadores em genes envolvidos diretamente no seu desenvolvimento propõe uma infinidade de estudos a serem realizados.

No final da década de oitenta, quatro genes responsáveis por promover a determinação e diferenciação das células musculares foram identificados e isolados: MyoD (Davis et al., 1987), Myf5 (Braun et al., 1989), miogenina (Edmonson \& Olson, 1989; Wright et al., 1989) e MRF4 (Rhodes \& Konieczny, 1989). Os fatores de transcrição codificados por estes genes são também denominados Fatores Regulatórios da Miogênese (MRF) e são capazes de desencadear a conversão de fibroblastos totipotentes em fibras musculares, pela ativação de genes músculo-específicos durante o desenvolvimento embrionário (revisado por Perry \& Rudnicki, 2000 e Pownall et al., 2002). Os genes MyoD e Myf5 atuam na determinação da linhagem miogênica de células precursoras na etapa inicial do desenvolvimento muscular, apresentando 
algumas funções redundantes, enquanto que a miogenina e MRF-4 são requeridos para a diferenciação bioquímica e morfológica para a maturação do tecido muscular esquelético (Perry \& Rudnicki, 2000).

A miostatina, um novo membro da família TGF- $\beta$ recentemente descrito por McPherron et al. (1997) em camundongos, tem se revelado um dos fatores mais relevantes para a regulação da formação da massa muscular, durante o desenvolvimento e crescimento do animal. Esta proteína atua como um potente regulador negativo do crescimento muscular esquelético, inibindo a proliferação de mioblastos durante a miogênese (Thomas, 2000).

A maioria das características quantitativas é determinada por muitos genes, cada um contribuindo com um pequeno efeito, entretanto alguns destes genes podem apresentar maior importância no controle de determinada característica quantitativa do que outros (Rothschild \& Soller,1999). Dentre as características quantitativas de maior interesse na avicultura de corte estão as de desempenho e carcaça, as quais estão relacionadas diretamente à capacidade de desenvolvimento muscular dos animais. Com base no exposto acima, o objetivo geral do presente estudo foi detectar polimorfismos em cinco genes candidatos (MyoD, Myf5, miogenina, MRF4 e miostatina) que atuam no desenvolvimento muscular de galinhas, em duas linhagens de composições genéticas distintas, uma de corte (TT) e outra de postura (CC); avaliar os efeitos das variantes alélicas sobre características de crescimento e desenvolvimento muscular em uma população experimental $\mathrm{F} 2$, proveniente do cruzamento das linhagens TT e CC; e investigar os efeitos de substituição alélica e interação entre os fatores miogênicos estudados sobre o fenótipo dos indivíduos da geração F2. 


\section{REVISÃO DE LITERATURA}

\subsection{Biotecnologia na avicultura}

A maior parte das organizações de melhoramento animal no mundo estão ativamente envolvidas em empregar ferramentas emergentes da análise genômica, para obter uma melhor compreensão da arquitetura molecular das características de produção (Georges, 2001). Na avicultura, a pesquisa genômica tem sido alvo de intensos estudos, dos quais se destacam: o isolamento e mapeamento de marcadores genéticos (crucial para o mapeamento de todo o genoma), o mapeamento de QTL, a identificação de genes candidatos e a descoberta de novos genes (Burt, 2002).

$\mathrm{Na}$ última década, um importante avanço na pesquisa genômica de galinhas foi a construção do mapa genético consenso, baseado nos mapas das populações referência de East Lansing (Bumstead \& Palyga, 1992), Compton (Crittenden et al., 1993) e Wageningen (Groenen et al., 1998). Neste mapa, foram mapeados 1.965 marcadores em 50 grupos de ligação, cobrindo aproximadamente 4000 cM (Groenen et al., 2000). O genoma da galinha compreende 39 pares de cromossomos, sendo um par de cromossomos sexuais $\mathrm{Z}$ e W, e 38 pares de autossomos. Dentre eles, oito pares incluindo $\mathrm{Z}$ e W, são macrocromossomos citologicamente distintos, e os demais são pares de microcromossomos citologicamente indistinguíveis (Ladjali-Mohammedi et al., 1999). Pesquisas abordando a integração dos mapas genéticos e citogenéticos têm sido realizadas pela técnica de hibridização in situ com a utilização de clones BAC e PAC, incluindo marcadores localizados em macro e microcromossomos (Morrisson et al. 1998; Smith et al.,2000). 
Certamente o maior avanço obtido até o momento foi a recente divulgação do seqüenciamento do genoma de galinha pelo Washington U. Genome Sequencing Center (WUGSC) e National Human Genome Research Institute, cuja montagem inicial foi baseada na cobertura de 6,6 vezes a seqüência do genoma (POULTRY GENOME NEWSLETTER, 2004). A identificação dos contigs ainda está em andamento e as seqüências depositadas já se encontram disponíveis nos bancos de dados do GenBank, EMBL-bank e DDBJ.

Embora as pesquisas em genômica funcional sejam mais recentes, cerca de 600.000 seqüências expressas ou EST (Expressed Sequence Tag) foram identificadas em uma variedade de tecidos de galinha e já se encontram disponíveis em bancos de dados na Internet (Vignal, 2004). Dentre estas seqüências, o Laboratório de Biotecnologia Animal - ESALQ/USP contribuiu com o seqüenciamento de aproximadamente 13.000 EST no banco de dados do NCBI, identificadas na hipófise (acesso c0419474-c0421626), hipotálamo (c042127-c0423759), tecido muscular dos membros (cd760792-cd765430) e peitoral (c0502869-c0507803). A maior contribuição até o momento, anunciada pelo European Union Consortium, foi o seqüenciamento de 339.314 EST de galinha de uma variedade de tecidos de embriões e aves adultas (Boarman et al., 2002).

Os resultados obtidos com o mapeamento de QTL, em conjunto com o seqüenciamento do genoma e os estudos de expressão gênica poderão auxiliar no entendimento dos mecanismos moleculares envolvidos nas variações fenotípicas de características de importância econômica (Vignal, 2004). A genética molecular aliada à genética quantitativa pode tornar mais eficientes as estratégias convencionais de seleção, de modo a aumentar a acurácia, promovendo maiores progressos genéticos no curto prazo.

Uma das maiores metas da pesquisa genômica na avicultura tem sido o mapeamento e identificação de locos que controlam características quantitativas (QTLQuantitative Trait Loci), cuja detecção pode ser realizada através da análise de todo o genoma utilizando-se marcadores microssatélites (Anderson et al.,1994) ou pela análise de genes candidatos (Rothschild \& Soller,1999). As informações provenientes da 
genética molecular podem ser usadas para implementar estratégias de melhoramento através da seleção assistida por marcadores (MAS - Marker Assisted Selection). Esta por sua vez, pode ser utilizada em conjunto com a seleção fenotípica na introgressão de determinada característica de uma população para outra, mantendo as características desejáveis da população receptora e também na predição do desempenho e heterose da progênie resultante de cruzamentos (Dekkers \& Hospital, 2002).

\subsection{Genes candidatos}

Genes candidatos são genes já seqüenciados, de ação biológica conhecida que estão envolvidos com o desenvolvimento ou fisiologia de determinada característica. Estes genes podem ser estruturais, regulatórios ou que participam de vias metabólicas, afetando a expressão do caráter (Bryne \& McMullen, 1996). O estudo de genes candidatos envolve uma série de etapas: escolha do gene, desenho de primers para amplificação, descoberta de polimorfismos, estabelecimento da técnica de genotipagem dos sítios polimórficos, formação de uma população referência para genotipagem e finalmente realização dos testes de associação com características fenotípicas desta população.

A técnica do gene candidato é uma forma abrangente de se pesquisar o genoma, uma vez que o gene é escolhido baseado em evidências de que o peptídeo que ele codifica tem efeito biológico ou fisiológico na característica de interesse. Nesta metodologia, é assumida a hipótese de que uma proporção significativa do QTL, o qual afeta a variação fenotípica de uma característica em uma dada população, na realidade corresponde a genes associados a estas características (Rothschild \& Soller, 1999).

O processo de identificação de QTL por meio de genes candidatos, baseia-se na detecção de polimorfismos conhecidos como SNPs (Single Nucleotide Polymorphisms) que possam estar associados com características de interesse, através de uma análise estatística apropriada, utilizando-se dados provenientes de uma amostra de população referência. Nesta metodologia os polimorfismos podem ser revelados por diversas técnicas, dentre elas a digestão com enzima de restrição e o seqüenciamento automático. 
A técnica de PCR-RFLP para identificação de polimorfismos tem sido utilizada em grande parte dos trabalhos publicados com genes candidatos e tem apresentado bons resultados.

Dentre as vantagens da análise de genes candidatos, estão o maior poder estatístico, obtido com menor número de famílias e indivíduos, quando comparada com análises de mapas ligação, a ampla aplicabilidade, uma vez que podem ser estudados em uma única geração, o baixo custo dos procedimentos de genotipagem em larga escala, e a simplicidade operacional, pois se pode trabalhar com um único gene e não com um genoma por inteiro (Rothschild \& Soller, 1999). Finalmente, uma vez validado, o polimorfismo do gene candidato pode ter utilização imediata na seleção assistida por marcadores na população testada (Rothschild \& Soller, 1999).

As limitações desse procedimento são o pequeno número de genes conhecidos que controlam características de interesse, o efeito pleiotrópico e de epistasia de outros genes sobre o gene candidato, o alto custo da etapa inicial de detecção de polimorfismos e a dificuldade no estabelecimento definitivo do efeito do gene candidato (Rothschild \& Soller, 1999). Além destes, o efeito de interação entre genótipo e ambiente também exerce grande influência. Até que se estabeleça a variante causal do gene responsável pelo seu efeito quantitativo, sempre haverá a possibilidade de que o gene estudado não seja o gene que realmente esteja causando a diferença na característica, mas esteja somente ligado ao QTL (Rothschild \& Soller, 1999). Isso pode levar a resultados contraditórios, dependendo da população estudada, pois associações significativas em uma população podem não ser verificadas em outras. Por exemplo, em estudos realizados por Linville et al. (2001) não houve associação significativa dos marcadores dos receptores do estrogênio (ESR) e da prolactina (PRLR), com o tamanho da leitegada em suas populações de suínos, enquanto que associação significativa foi observada anteriormente nas populações utilizadas por Short et al. (1997) e Vincent et al.(1998).

O poder estatístico do teste de associação neste tipo de análise é maior quando regiões polimórficas usadas para genotipar o gene candidato estão em completo desequilíbrio de ligação, causando variação na função do gene candidato, isto é na sua 
região funcional (Rothschild \& Soller, 1999). Segundo estes autores, as análises de genes candidatos, aplicadas dentro de uma população experimental, proveniente do cruzamento entre duas linhagens divergentes, irá gerar desequilíbrio de ligação envolvendo grande blocos de cromossomos contendo centenas de genes, o que permitirá a análise das regiões polimórficas e sua associação a características fenotípicas.

Em aves, genes candidatos para algumas mutações foram identificados ou sugeridos por estudos genéticos ou fisiológicos, por ocasionarem alterações morfológicas, possibilitando a compreensão do vínculo existente entre o fenótipo e o genótipo (Tixier-Boichard, 2000). Nestes estudos, foi observado que algumas mutações em genes específicos ocasionavam defeitos moleculares, indicando que alguns genes estariam desempenhando papel crucial no fenótipo, independente da complexidade da função (Tixier-Boichard, 2000). Uma das primeiras descobertas foi o gene recessivo do nanismo ligado ao sexo (Dw), descrido em uma variedade de linhagens de galinhas (Hutt, 1959). Estudos extensos sobre o desempenho, fisiologia e endocrinologia de aves anãs sugeriram que o receptor do hormônio do crescimento GHR, mapeado no cromossomo $\mathrm{Z}$, poderia ser o gene candidato, o que levou à identificação de três diferentes mutações neste gene (Tixier-Boichard, 2000).

Outros genes candidatos para algumas mutações em aves foram revelados da mesma forma, como por exemplo a deleção de seis bases no gene da tirosinase, a qual foi relacionada com o albinismo (Tobita-Teramoto et al, 2000), e o receptor da rianodina (RYR1), associado ao “crooked neck dwarf”, cuja mutação causa severa malformação da musculatura esquelética, levando ao desenvolvimento embrionário anormal (Groenen et al., 2000).

Alguns exemplos de estudos realizados sobre a associação de marcadores em genes candidatos com características de produção e resistência à doenças estão descritos nas tabelas 1 e 2 , respectivamente. 
Tabela 1. Resultados obtidos pela análise de genes candidatos relacionados à caracteres de produção

\begin{tabular}{|c|c|c|c|c|c|}
\hline Gene & $\begin{array}{l}\text { Caracteres } \\
\text { avaliados }\end{array}$ & $\begin{array}{l}\text { Caracteres } \\
\text { associados }\end{array}$ & RFLP & Linha & Referência \\
\hline $\mathrm{GH}$ & $\begin{array}{l}\text { Idade a } 1^{\circ} \text { postura } \\
\text { produção de ovos total } \\
\text { Taxa de postura } \\
\text { e peso do ovo } \\
\text { Gravidade específica }\end{array}$ & $\begin{array}{l}\text { Idade a } 1^{\circ} \text { postura } \\
\text { produção de ovos total } \\
\text { Taxa de postura }\end{array}$ & $\begin{array}{l}\text { MspI } \\
\text { SacI }\end{array}$ & $\begin{array}{l}\text { White } \\
\text { Leghorn }\end{array}$ & Kuhlein et al.1997 \\
\hline $\mathrm{GH}$ & $\begin{array}{l}\text { Peso aos } 140 \text { dias } \\
\text { Idade a } 1^{\circ} \text { postura } \\
\text { taxa de produção de ovos }\end{array}$ & $\begin{array}{l}\text { Idade a } 1^{\circ} \text { postura } \\
\text { Taxa de postura }\end{array}$ & MspI & $\begin{array}{l}\text { White } \\
\text { Leghorn }\end{array}$ & Feng et al., 1997 \\
\hline GHR & $\begin{array}{l}\text { peso do ovo } \\
\text { Gravidade específica }\end{array}$ & --------------- & SacI & & \\
\hline IGF-I & $\begin{array}{l}\text { Idade a } 1^{\circ} \text { postura } \\
\text { taxa de produção de ovos } \\
\text { Peso corporal } \\
\text { consumo } \\
\text { Peso do ovo } \\
\text { Gravidade específica } \\
\text { Peso da casca do ovo }\end{array}$ & $\begin{array}{l}\text { Peso do ovo } \\
\text { Gravidade específica } \\
\text { Peso da casca do ovo }\end{array}$ & PstI & $\begin{array}{l}\text { White } \\
\text { Leghorn }\end{array}$ & Nagaraja et al., 2000 \\
\hline IGF-1 & $\begin{array}{l}\text { Peso corporal } \\
\text { Ganho de peso médio } \\
\text { Consumo }\end{array}$ & $\begin{array}{l}\text { Ganho de peso médiob } \\
\text { Eficiência alimentar }^{\mathrm{b}}\end{array}$ & HinfI & $\begin{array}{l}\text { Black } \\
\text { Penedese } \\
\text { nca }\end{array}$ & Amills et al., 2003 \\
\hline IGF-2 & Eficiência alimentar & -------------- & $\begin{array}{l}\text { Hsp } 92 \\
\text { II }\end{array}$ & & \\
\hline
\end{tabular}

${ }^{\mathrm{a}}$ Cosselecionados para resistência a leucose aviária e doença de Marek.

${ }^{\mathrm{b}}$ Estatisticamente significativo dentro de uma linhagem. 
Tabela 2. Resultados obtidos pela análise de genes candidatos envolvidos nos mecanismos imunológicos relacionados à resistência a inoculação de Salmonella enteritidis

\begin{tabular}{|c|c|c|c|c|c|}
\hline Gene & $\begin{array}{l}\text { Caracteres } \\
\text { avaliados }\end{array}$ & $\begin{array}{l}\text { Caracteres } \\
\text { associados }\end{array}$ & RFLP & Linha & Referência \\
\hline INOS & C. de bactérias baço ${ }^{\mathrm{a}}$ & & AluI & & Malek \& \\
\hline TRAIL & C. de bactérias ceco ${ }^{\mathrm{a}}$ & C. de bactérias baço ${ }^{\mathrm{a}}$ & StyI & $\begin{array}{c}\mathrm{X} \\
\mathrm{xHCh}\end{array}$ & Lamont, 2003 \\
\hline & Nível de anticorpos & & & & \\
\hline TGF- $\beta 2$ & após a vacina & ---------- & RsaI & & \\
\hline TGF- $\beta 3$ & & C. de bactérias ceco ${ }^{a}$ & BsrI & & \\
\hline $\operatorname{IgL}$ & & C. de bactérias figado ${ }^{\mathrm{a}}$ & Sau96I & & \\
\hline SLC11A & C. de bactérias baço ${ }^{a}$ & C. de bactérias ceco ${ }^{\mathrm{a}}$ & SacI & Old Dutch & Kramer et al., \\
\hline 1 & C. de bactérias ceco ${ }^{\mathrm{a}}$ & C. de bactérias fígado ${ }^{a}$ & & Breed & 2003 \\
\hline IAP1 & C. de bactérias fígado & C. de bactérias ceco ${ }^{\mathrm{a}}$ & $\mathrm{BgI}$ & & \\
\hline PSAP & & C. de bactérias ceco $^{\mathrm{a}}$ & TfI & & \\
\hline CASP & & $\begin{array}{l}\text { C. de bactérias ceco }{ }^{\mathrm{a}} \\
\text { C. de bactérias fígado }\end{array}$ & Hsp92 II & & \\
\hline INOS & & C. de bactérias ceco ${ }^{\mathrm{a}}$ & AluI & & \\
\hline IFNG & & ------------' & Tsp509 & & \\
\hline IL2 & & $\begin{array}{l}\text { C. de bactérias ceco }{ }^{\mathrm{a}} \\
\text { C. de bactérias fígado }\end{array}$ & $\mathrm{MnI}$ & & \\
\hline $\operatorname{IgL}$ & & $\begin{array}{l}\text { C. de bactérias ceco }{ }^{\mathrm{a}} \\
\text { C. de bactérias fígado }\end{array}$ & Sau96 I & & \\
\hline ZOV3 & & ------------- & SnaBI & & \\
\hline TGF- $\beta 2$ & & C. de bactérias ceco ${ }^{\mathrm{a}}$ & RsaI & & \\
\hline TGF- $\beta 3$ & & C. de bactérias baço ${ }^{\mathrm{a}}$ & BsrI & & \\
\hline TGF- $\beta 4$ & & $\begin{array}{l}\text { C. de bactérias ceco }{ }^{\mathrm{a}} \\
\text { C. de bactérias figado }\end{array}$ & MboII & & \\
\hline $\begin{array}{l}\text { TLR4 } \\
\text { CD28 }\end{array}$ & C. de bactérias baço ${ }^{\mathrm{a}}$ & & Sau96I & Fayoumi & Malek et al.., \\
\hline $\mathrm{CD} 28$ & $\begin{array}{l}\text { C. de bactérias ceco } \\
\text { Nível de anticorpos } \\
\text { após a vacina }\end{array}$ & $\begin{array}{l}\text { C. de bactérias ceco } \\
\text { Nível de anticorpos } \\
\text { após a vacina }\end{array}$ & RsaI & MHCLeghorn & 2003 \\
\hline MIF & & C ------------ & $-\overline{c o-}$ & & \\
\hline MD-2 & & C. de bactérias baço ${ }^{\mathrm{a}}$ & AseI & & \\
\hline LITAF & & ------------ & HinfI & & \\
\hline
\end{tabular}

${ }^{a}$ Carga de bactérias após inoculação com Salmonella enteritidis.

O estudo de genes candidatos é amplamente aplicado também a outras espécies. Em suínos, polimorfismos identificados no gene do halotano relacionado com a incidência de PSE (Pale, Soft and Exudative Meat), são rotineiramente usados como marcadores em programas na seleção (De Vries et al., 1998). A identificação de um 
alelo dominante no gene $\mathrm{RN}^{-}$também foi relacionado com a redução da qualidade de carne em suínos, uma vez que caracteriza a incidência de fibras brancas glicolíticas de contração rápida (De Vries et al., 1998). Em bovinos, deleções no gene da miostatina foram associadas com a formação da musculatura dupla nas raças Belgian Blue e Piamontesa (McPherron \& Lee, 1997; Grobet et al. 1997). Estes resultados indicam que determinados genes possuem maior relevância no fenótipo de algumas características, apesar da complexidade dos mecanismos moleculares envolvidos na sua fisiologia.

\subsection{Marcadores SNPs}

Como sugerido pela sigla, um marcador SNP (Single Nucleotide Polymorphism) é caracterizado por uma única substituição de base na seqüência de DNA, com a alternativa usual de dois possíveis nucleotídeos em uma dada posição (Vignal et al., 2002). Para que tal posição seja considerada como um SNP, assume-se que o alelo menos freqüente tenha abundância acima de 1\%. A princípio, os SNPs podem ser polimorfismos bi-, tri-, ou tetralélicos, entretanto na prática são em geral bialélicos (Brookes, 1999). Os SNPs podem ser classificados como sinônimos (sSNP), quando não implicam em substituição de aminoácidos, e não-sinônimos quando causam alterações na seqüência de aminoácidos (nSNP). Milhares destes marcadores já foram identificados em galinhas, detectados em seqüências EST e se encontram depositados no banco de dados do NCBI.

Os mecanismos de mutação resultam tanto em transições: substituições purinapurina $(A \Leftrightarrow \mathrm{G})$ ou pirimidina-pirimidina $(\mathrm{C} \Leftrightarrow \mathrm{T})$; como em transverções: substituições purina-pirimidina ou pirimidina-purina $(A \Leftrightarrow C, A \Leftrightarrow T, G \Leftrightarrow C, G \Leftrightarrow$ T). O grande número de SNPs caracterizados por substituições $\mathrm{C} \Leftrightarrow \mathrm{T}$ e $\mathrm{G} \Leftrightarrow \mathrm{A}$, pode ser explicado pela alta taxa de reação de desaminação espontânea da 5-metilcitosina $(5 \mathrm{mC})$ para timidina, que são conhecidas por ocorrer freqüentemente em dinucleotídeos CpG (Cooper e Krawzack, 1989). Alguns autores consideram inserções e deleções de pares de base (indels) como SNPs, embora certamente ocorram por um mecanismo diferente (Vignal et al., 2002). 
Recentemente os marcadores SNPs têm sido utilizados com uma nova abordagem na pesquisa genômica aplicada ao melhoramento: na identificação de genes candidatos em pesquisas de mapeamento de QTL. Uma vez que o genoma possui o potencial para fornecer milhares de marcadores SNPs em alta densidade e distribuídos homogeneamente em todos os cromossomos, é possível melhorar a resolução dos mapas de ligação para identificação de QTL já realizada com marcadores microssatélites, permitindo o mapeamento de genes candidatos. A descrição da arquitetura genética de características quantitativas não está completa até que se possa especificar quais sítios polimórficos em um gene correspondem ao QTL que de fato seja a causa da diferença no fenótipo da característica. Estes sítios caracterizados por SNPs são denominados QTNs (Quantitative Trait Nucleotides) (Mackay, 2001). Se os genótipos de todos os sítios polimórficos na região de interesse são determinados, um deles deve corresponder ao sítio que ocasiona o efeito fenotípico. Os mesmos métodos utilizados no mapeamento de desequilíbrio de ligação para a identificação de genes candidatos podem ser usados também para determinar quais dos sítios polimórficos no gene candidato está associado com o fenótipo da característica quantitativa (Mackay, 2001).

\subsection{Formação da fibra muscular}

A miogênese esquelética é iniciada no embrião como resultado de uma intrincada rede de sinais provenientes de estruturas adjacentes, as quais especificam o destino miogênico de células precursoras musculares (Buckingham, 2001). Mediante estes sinais, células precursoras de origem mesodérmica ativam o programa miogênico, sendo capazes de proliferar e estabelecer um pool de células denominadas mioblastos. Sinais específicos levam os mioblastos a saírem do ciclo celular, e darem início à etapa de diferenciação, através da síntese de proteínas músculo-específicas. Por fim, os mioblastos diferenciados se fundem formando miotubos multinucleados, os quais darão origem às fibras musculares (Rehfeldt et al., 2000). Durante a miogênese, os miotubos se desenvolvem em duas fases temporariamente distintas. As miofibras primárias se formam na primeira onda de diferenciação, durante os estágios iniciais de fusão dos 
mioblastos, fornecendo um arcabouço para a ampla população de fibras secundárias menores. Estas, por sua vez se formam a partir dos mioblastos fetais durante a segunda onda de diferenciação (Rehfeldt et al., 2000, Picard et al.,2002).

\subsection{Origem Embriológica da Musculatura Esquelética}

A musculatura esquelética dos vertebrados se origina do mesoderma paraxial do embrião durante a gastrulação, o qual pode ser dividido em: mesoderma paraxial não segmentar, somitos e placa segmentar. O mesoderma da placa segmentar surge com a invaginação do epiblasto a partir do nó de Hensen, ao longo da linha primitiva. À medida que esta regride, novas células mesenquimais são adicionadas continuamente à extremidade caudal da placa segmentar, entre os estágios 4 e 15 (Hamburger \& Hamilton, 1951). Com exceção dos músculos da cabeça, todos os demais músculos esqueléticos de vertebrados são derivados dos somitos, os quais dão origem à musculatura axial, do tronco e dos membros (Ludolph \& Konieczny, 1995). Os somitos são blocos de células mesenquimais, originadas do mesoderma paraxial bilateral, os quais se encontram dispostos seqüencialmente em ambos os lados das estruturas axiais do embrião, o tubo neural e a notocorda (Ludolph \& Konieczny, 1995; Christ \& Ordahl, 1995, Buckingham et al. 2000). Os pares de somitos são formados na extremidade rostral da placa segmentar, sendo que a maturação ocorre no sentido crânio-caudal do embrião em um processo contínuo (Stockdale et al., 2000). Como conseqüência, somitos em diferentes etapas de maturação estão presentes em todos os estágios de desenvolvimento do embrião.

O futuro somito começa a sofrer compartimentalização antes mesmo de emergir da extremidade rostral da placa segmentar, quando a maior parte destas células se torna densamente empacotada e polarizada (com exceção das células localizadas centralmente, que irão ocupar o lúmen do somito), sugerindo uma transição mesênquima-epitélio que ocorre à medida que os somitos se formam (Stockdale, 2000).

A maturação do somito recém formado (figura 1) denominado somito epitelial, é caracterizada por mudanças na organização, determinação e diferenciação das células 
dos somitos, ao longo de três eixos principais do embrião: dorso-ventral, médio-lateral e rostro-caudal (Pourquié, 2001; Stockdale, 2000). Após o brotamento, a porção ventral do somito epitelial sofre uma nova transição epitélio-mesênquima para formar o esclerótomo, cujas células são precursoras dos ossos e cartilagens, que darão origem ao esqueleto axial e às costelas. A porção dorsal do somito, agora chamada dermomiótomo, mantém sua natureza epitelial e suas células darão origem aos músculos esqueléticos, à derme e aos derivados vasculares (Stockdale, 2000). Conforme a maturação do somito progride, o dermomiótomo se estende lateralmente dorso e ventralmente, dando origem a dois subdomínios: o epaxial, na região dorso-medial adjacente ao tubo neural, e o hipaxial, na região da borda ventro-lateral (Stockdale, 2000; Buckingham, 2003).

O miótomo dá origem a todos os músculos epaxiais do embrião de vertebrados (Stockdale, 2000). Suas células são derivadas do lábio dorso-medial (LDM) e ventrolateral (LVL) do dermomiótomo, que delaminam e translocam para a região ventral do dermomiótomo (Denetclaw \& Ordahl, 2000) em resposta a uma complexa rede de sinais procedentes de estruturas adjacentes incluindo o tubo neural, a notocorda, a superfície da ectoderme e o mesoderma intermediário e lateral (Arnold \& Braun, 2000). Esta delaminação é seguida por uma migração longitudinal de células para as bordas rostral e caudal do dermomiótomo, local onde se diferenciam (Cinnamon et al., 2001). 
(A)

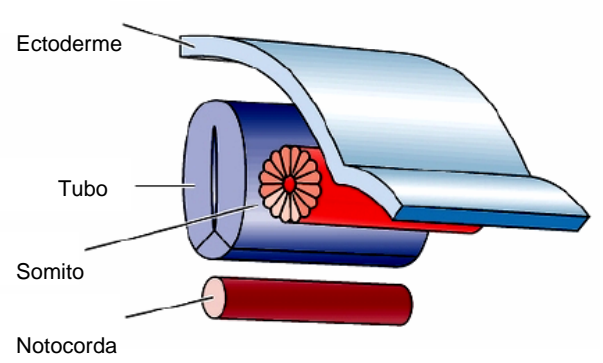

(B)
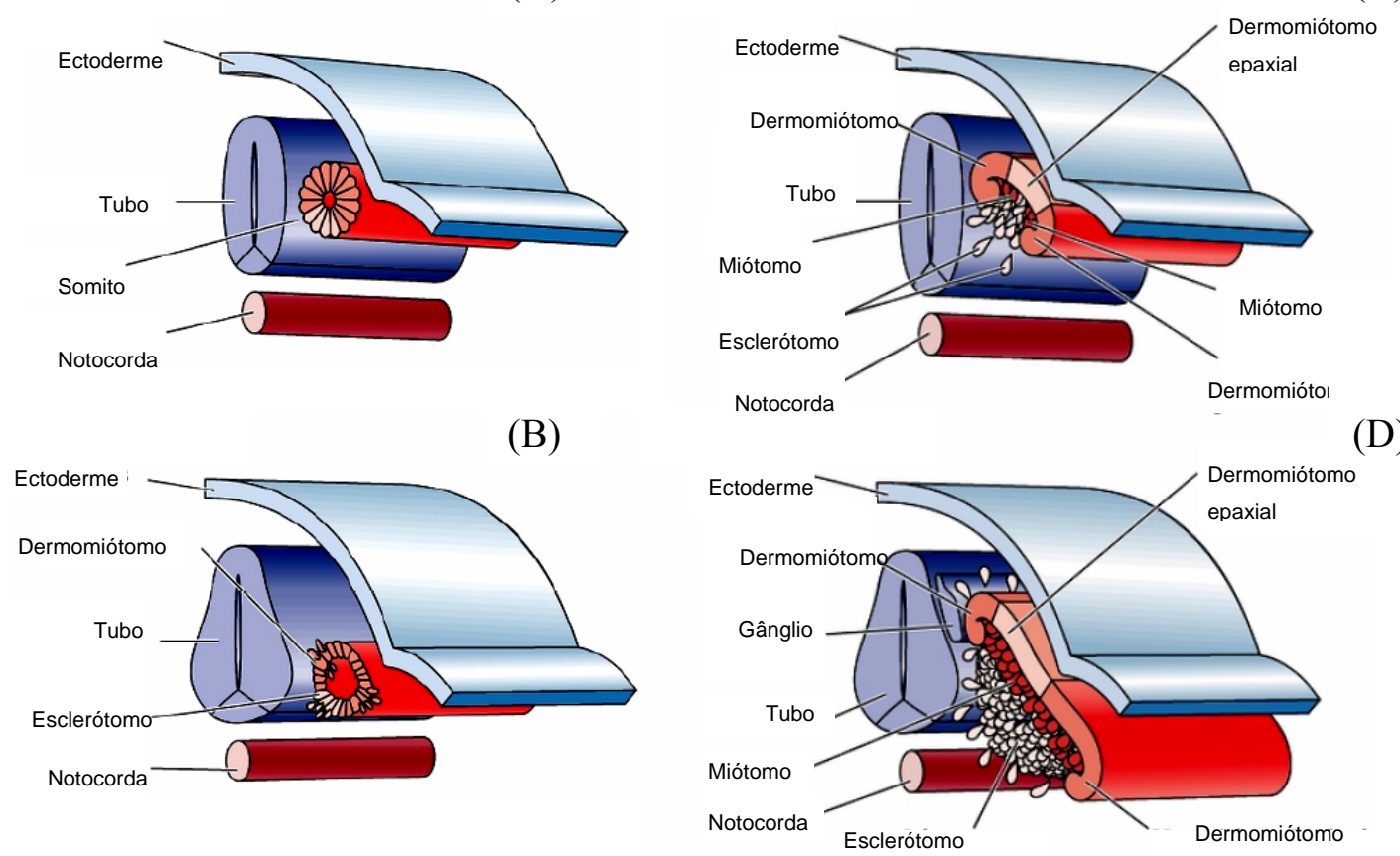

Figura 1 - Maturação do somito epitelial. A figura ilustra a subdivisão do somito em compartimentos: o esclerótomo, o dermomiótomo e seus subdomínios e o miótomo, originado pela migração das células do dermomiótomo epaxial e hipaxial, durante e após o processo de brotamento da placa segmentar

Fonte: adaptada de Gilbert (2003)

Os músculos dos membros são formados por células derivadas do dermomiótomo hipaxial de somitos localizados próximos aos primórdios dos pares de membros. Nestas regiões, células progenitoras do epitélio do dermomiótomo hipaxial, delaminam e migram para os primórdios dos membros, onde as massas musculares dorsais e ventrais serão formadas (Brand-Saberi \& Christ, 1999; Buckingham et al., 2003). Uma vez no membro, as células precursoras dos somitos seguem um destino exclusivamente miogênico, onde continuam a proliferar e posteriormente se diferenciar, uma vez que qualquer área de brotação do membro contém sinais que induzem a miogênese em células provenientes dos somitos (Christ \& Brand-Saberi, 2002). 


\subsection{Fatores regulatórios da miogênese}

Fatores miogênicos são fatores de transcrição que quando expressos, são capazes de desencadear a conversão de fibroblastos totipotentes em fibras musculares, pela ativação de genes-músculo específicos durante o desenvolvimento embrionário. A formação de células altamente especializadas, como as fibras musculares esqueléticas, requer a correta combinação da expressão espacial e temporal de uma série de genes reguladores e músculo-específicos (Ludolph e Konieczny, 1995). Este processo envolve a determinação e a proliferação de linhagens miogênicas de células precursoras (mioblastos), e subseqüente diferenciação, caracterizada pela interrupção do ciclo celular, síntese de proteínas músculo-específicas e fusão de mioblastos em células multinucleadas.

As primeiras evidências sobre a descoberta dos fatores miogênicos foram obtidas em experimentos realizados em uma linha de células tronco do mesoderma C3H10T1/2, que crescem como fibroblastos em cultura. Foi observado que estas células têm a capacidade de se converter em mioblastos quando brevemente expostas ao agente desmetilante 5-azacitidina durante a divisão celular (Taylor \& Jones, 1979). Este agente possui estrutura similar a citidina, porém contém um átomo de nitrogênio em lugar do carbono 5 do anel da base nitrogenada, posição onde ocorre a maior parte dos eventos de metilação de DNA. Desta forma, o DNA replicado das gerações seguintes de células C3H10T $1 / 2$, incorpora 5 -azacitidina e não pode ser metilado, uma vez que não é substrato para metilases, desencadeando o programa miogênico, com uma freqüência de conversão acima de 50\% (Taylor \& Jones, 1979).

Com base nesta descoberta, Davis et al. (1987) realizaram um estudo em bibliotecas de cDNA obtidas por hibridização subtrativa de células tratadas e não tratadas com 5-azacitidina, no qual identificaram e isolaram o primeiro fator miogênico, denominado MyoD. Subseqüentemente, outros três fatores, capazes de gerar o fenótipo de músculo esquelético quando superexpressos em fibroblastos $10 \mathrm{~T}^{1 / 2}$ ou em várias outras linhagens de células, foram identificados em experimentos similares: miogenina (Edmonson \& Olson, 1989; Wright et al., 1989), Myf5 (Braun et al., 1989), e MRF4 
(Rhodes \& Konieczny, 1989). O último foi independentemente isolado como Herculina (Miner \& Wold, 1990), e Myf-6 em humanos (Braun et al., 1990).

O gene MyoD da galinha está localizado no cromossomo 5, possui 7376 pares de bases incluindo a região promotora, três exons e dois introns. Sua seqüência nucleotídica completa está disponível no banco de dados do NCBI sob os acessos L34006 e GeneID-374048. O gene da miogenina da galinha está localizado no cromossomo 32 e parte de sua seqüência nucleotídica se encontra disponível no banco de dados do NCBI, sob o acesso GeneID-374004. O fragmento de cDNA clonado por Fujisawa-Sehara et al. (1990) está despositado sob o número de acesso D90157. O gene Myf5 está localizado no cromossomo 1 e parte de sua seqüência, incluindo um total de 1609 pares de bases envolvendo três exons e dois introns, está disponível no banco de dados do NCBI sob o acesso X73250 e GeneID-395633. O gene MRF4 também está localizado no cromossomo 1 próximo ao gene Myf5 e parte de sua seqüência está disponível sob o acesso GeneID-LOC417873. O fragmento de cDNA clonado por Fujisawa-Sehara et al.(1990) está despositado sob o número de acesso D10599.

\subsubsection{Propriedades estruturais das proteínas MRF}

Os Fatores Regulatórios da Miogênese (MRFs), também conhecidos como membros da família MyoD de fatores miogênicos, são fosfoproteínas nucleares estruturalmente semelhantes, as quais compartilham duas regiões funcionais de homologia: um domínio básico, caracterizado por uma seqüência de aminoácidos positivamente carregados, e o domínio hélice-alça-hélice (HLH, helix-loop-helix) caracterizado por duas $\alpha$-hélices anfipáticas, separadas por uma alça de tamanho variável (Ludolph \& Konieczny, 1995). Devido à presença destes dois domínios, estas proteínas também são chamadas de proteínas básicas HLH (figura 2). 


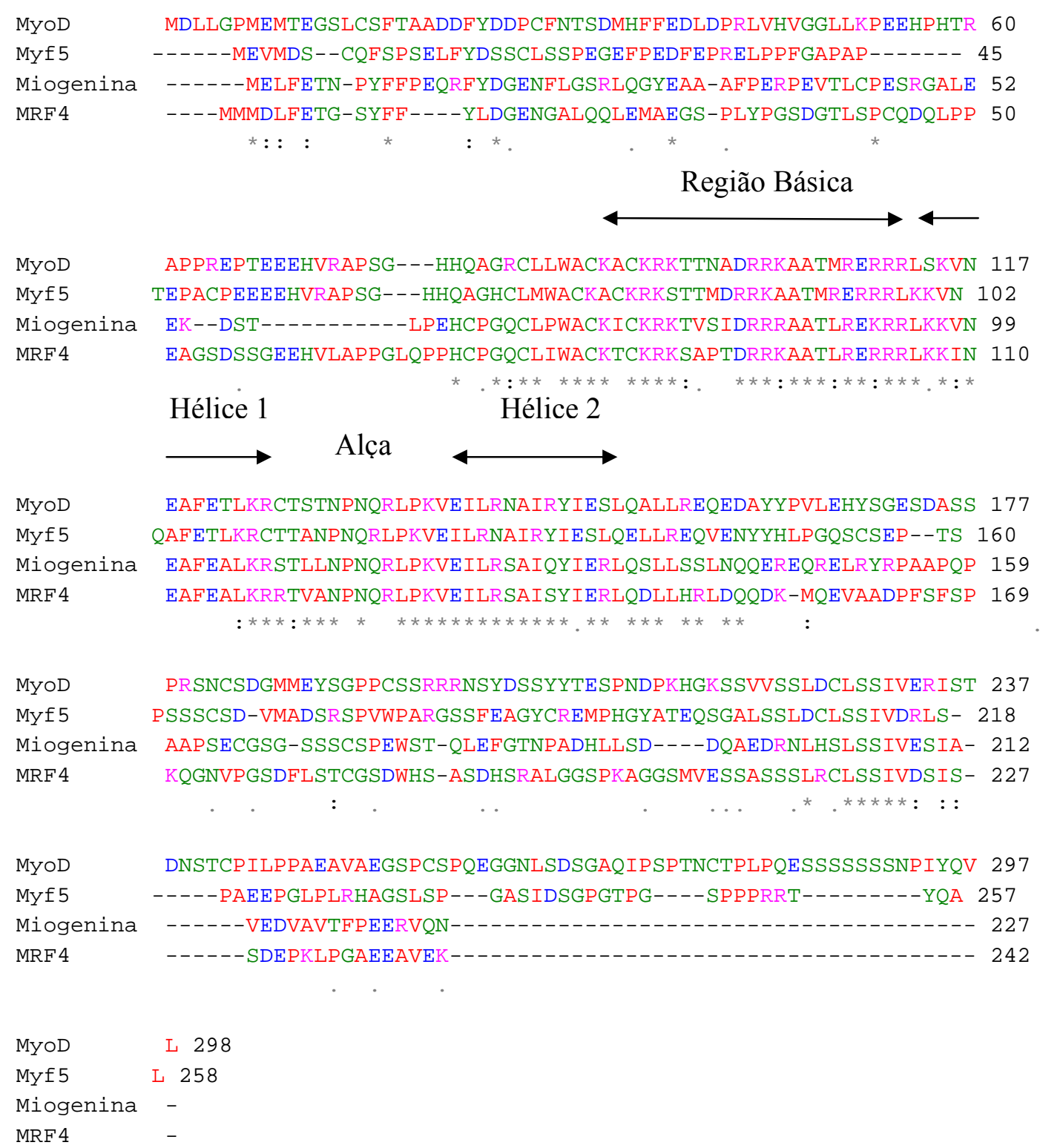

Figura 2 - Alinhamento das seqüências traduzidas dos genes da família MyoD de Gallus gallus, realizado pelo ClustalW multiple sequence alignment (www.ebi.ac.uk/clustalw). Vermelho - resíduos hidrofóbicos e aromáticos; azul - resíduos negativamente carregados; magenta - resíduos positivamente carregados; verde - outros resíduos polares. (*) - Os resíduos nessa coluna são idênticos em todas as seqüências do alinhamento; (:) - substituições conservadas identificadas por letras da mesma cor; (.) - substituições semiconservadas 
O domínio básico media a ligação entre o fator miogênico e uma seqüência de DNA específica (CANNTG), conhecida como E-box, presente em regiões promotoras e ou enhancers de vários genes músculo-específicos (Weintraub et al., 1991; Sabourin \& Rudnicki, 2000). A eficiente interação entre os fatores miogênicos e o DNA é alcançada pela heterodimerização destes com outras proteínas bHLH não miogênicas da família de proteínas ubíquas-E, tais como E12, E47, HEB e ITF (Puri \& Sartorelli, 2000). A formação do heterodímero ocorre através do domínio HLH, presente em ambas as proteínas. O domínio bHLH é altamente conservado entre os MRFs, enquanto que as extremidades amino e carboxil terminais apresentam homologia limitada como observado na figura 2, sugerindo que estes fatores podem exercer funções redundantes durante o desenvolvimento muscular (Puri \& Sartorelli, 2000).

Outros domínios não compartilhados entre os MRF sugerem que estes genes possuem algumas funções específicas. Um exemplo disto são os gene MyoD e Myf5, que possuem domínios funcionais potencialmente envolvidos com a remodelagem da cromatina e na regulação do ciclo celular (Buckingham, 2001).

\subsubsection{Expressão espacial e temporal dos fatores miogênicos}

Trabalhos sobre expressão gênica dos MRFs, dentre outros genes reguladores, têm sido realizados através da detecção de mRNA em embriões pela utilização de técnicas de hibridização in situ, permitindo avaliar o padrão espacial e temporal de expressão destes genes. Esta técnica permitiu a identificação de MRFs expressos especificamente em diferentes linhagens de células dos somitos.

A expressão dos genes da família MyoD é estritamente limitada às células da musculatura esquelética, excluindo músculos lisos e cardíacos. Entretanto, tem sido demonstrado que o gene Myf5 também é expresso no tubo neural em desenvolvimento e domínios definidos do cérebro (Arnold \& Braun, 2000).

Em linhagens de células musculares e células primárias em cultura, MyoD e Myf5 são expressos em mioblastos durante a etapa de proliferação e continuam presentes em níveis reduzidos em miócitos diferenciados (Arnold \& Braun, 2000). Estes 
genes são ativados nas células precursoras do lábio dorso-medial (LDM) e ventro-lateral (LVL) do dermomiótomo, os quais formam os músculos epaxiais e hipaxiais respectivamente. São também ativados nas células precursoras dos músculos hipaxiais, que dão origem aos músculos ventrais do corpo e os músculos dos membros na região dos primórdios (Pownall et al., 2002).

Os fatores miogênicos são expressos seqüencialmente ao longo do eixo crâniocaudal do embrião, havendo alguma variação quanto à ordem de expressão destes fatores em diferentes espécies. No momento da formação dos somitos, durante a segmentação, os genes Myf5 e MyoD são expressos nas células progenitoras epaxiais, primeiramente nos somitos occipitais e cervicais, os quais dão origem aos músculos do pescoço, faringe, laringe e língua; e continuam sendo expressos à medida que novos somitos são formados nas regiões dos membros, tronco e cauda, ao longo do eixo axial do embrião (Pownall et al., 2002). Durante a maturação dos somitos, Myf5 e MyoD continuam sendo expressos no LDM, cujas células progenitoras se diferenciam conforme migram ventralmente para formar o miótomo (Borycki et al., 1997).

No LDM dos somitos jovens, os transcritos de Myf5 e MyoD são instáveis e sua expressão continuada requer sinais constantes provenientes do tubo neural e notocorda, para iniciar a diferenciação do miótomo, momento a partir do qual a expressão se torna independente destes sinais (Gustafsson et al., 2002).

Em contraste, a miogenina não está presente nos mioblastos, porém começa a se acumular no princípio da diferenciação, enquanto que o MRF4 é expresso nas etapas finais da diferenciação se tornando predominante na fase pós-natal e adulta (Arnold \& Braun, 2000).

Estas observações levam ao conceito de que MyoD e Myf5 atuam em eventos mais remotos da miogênese, possivelmente na determinação de mioblastos, enquanto que a miogenina, e provavelmente o MRF4 parecem estar envolvidos no programa de diferenciação terminal das células musculares. Isto tem sido confirmado em experimentos nocaute gênico em camundongos, bloqueando um ou vários membros da família MyoD (figura 3). Entretanto deve-se observar que os genes bHLH, os quais atuam na determinação dos mioblastos podem também contribuir para a diferenciação, 
quando presentes em altas concentrações. Assim, os processos de determinação e diferenciação não podem ser vistos como dois processos completamente isolados, mas sim como eventos redundantes na formação do músculo (Arnold \& Braun, 2000).
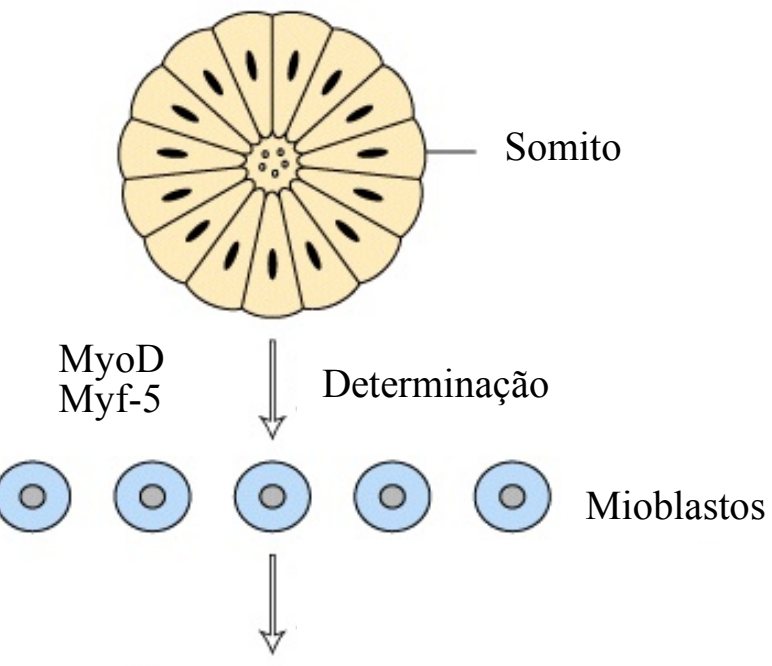

Massa pré-muscular

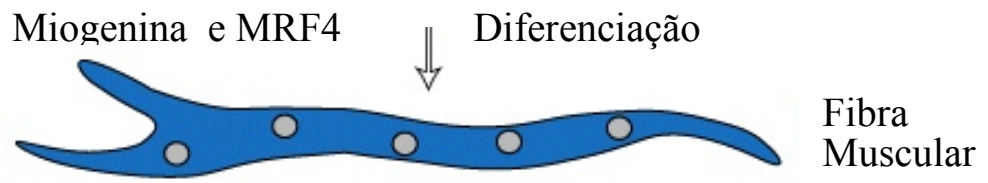

Figura 3 - Expressão temporal dos fatores miogênicos durante o desenvolvimento da musculatura esquelética. MyoD e Myf5 atuam na determinação de mioblastos, enquanto que a miogenina, e o MRF4 estão envolvidos no programa de diferenciação terminal das células musculares (Weintraub et al., 1991)

Fonte:http://www.anslab.iastate.edu/Class/AnS445545X/Somite\%20differentiation/Diffe rentiation \%20within\%20Somites.ppt (15/08/2004) 


\subsubsection{Papel funcional dos fatores miogênicos na formação da musculatura esquelética}

Estudos in vitro sugerem que todos os membros da família MyoD têm propriedades bioquímicas e atividades miogênicas similares, o que dificulta a caracterização da contribuição individual de cada um dos fatores na miogênese. Neste contexto, experimentos de nocaute dos genes da família MyoD possibilitaram a definição da atuação individual dos genes no comprometimento das células precursoras, proliferação de mioblastos e diferenciação terminal, bem como na maturação e regeneração do músculo esquelético sob condições fisiopatológicas. Além disso, a combinação de genes MRFs inativados revelou que algumas de suas funções se sobrepõem, enquanto outras são mais específicas.

\section{MyoD}

A inativação do gene $\mathrm{MyoD}$ não ocasionou alterações no fenótipo dos camundongos homozigotos mutantes quando comparados ao tipo selvagem durante o desenvolvimento inicial, levando-se em consideração tanto aspectos histológicos como funcionais (Rudnicki et al., 1992). Este resultado sugeriu que a presença da proteína MyoD não é essencial para promover o desenvolvimento normal do músculo esquelético, corroborando com a afirmativa de que algumas funções dos membros da família MyoD são redundantes, tendo em vista suas propriedades estruturais e bioquímicas similares. Os mutantes homozigotos apresentaram níveis normais de transcritos dos genes MRF4 e miogenina, enquanto que os transcritos de Myf5 se apresentaram drasticamente elevados, quando comparados aos do tipo selvagem (Rudnicki et al., 1992).

Posteriormente, Megeney et al. (1996) observaram que mutantes adultos apresentavam déficit na regeneração muscular, indicando que este gene atua também no recrutamento de células satélites após a ocorrência de lesões musculares. 


\section{Myf5}

Em experimentos realizados por Tajbakhsh et al. (1996a) e Braun et al. (1992), os alelos mutantes do gene Myf5 foram gerados por recombinação homóloga em camundongos, resultando na formação de uma proteína Myf5 não funcional. Nos camundongos mutantes homozigotos, houve a formação incompleta das partes distais das costelas, entretanto todos os músculos esqueléticos apresentaram-se morfologicamente normais. A ausência de uma caixa torácica funcional resultou na morte dos camundongos logo após o nascimento. Segundo este resultado, o gene Myf5 parece ser dispensável ao desenvolvimento dos músculos esqueléticos, enquanto que exerce papel crucial para a formação das costelas. Visto que as costelas se originam do esclerótomo, e que a expressão do Myf5 durante a miogênese é limitada à região do miótomo nos somitos, novos estudos realizados por Tajbaksh et al. (1996b) demonstraram que na ausência da proteína Myf5 as células do miótomo não se diferenciam e migram do miótomo central para o esclerótomo ventral e o dermátomo dorsal, onde expressam os genes escleraxis e Dermo-1, comumente expressos em células condrogênicas e epidermais, respectivamente. Este fato indicou que o Myf5 é essencial na determinação e manutenção das linhagens miogênicas de células multipotentes presentes no miótomo (Arnold \& Braun, 2000).

\section{MyoD e Myf5}

Embora a inativação dos genes MyoD e Myf5 isoladamente resultem em fenótipos aparentemente normais, a inativação de ambos os genes leva a uma completa ausência de musculatura esquelética em animais mutantes, bem como a ausência de qualquer célula precursora mononucleada (Rudnicki et al., 1993). As regiões de formação de músculo são parcialmente desprovidas de células musculares ou ocupadas por um mesênquima frouxo, o qual se apresenta inteiramente livre de transcritos músculo-específicos e demais fatores miogênicos (Rudnicki et al., 1993). A ausência de miócitos não é restrita aos músculos originados de somitos, mas também envolve aqueles derivados da placa do mesoderma precordal, tais como os músculos extraoculares. Portanto, os genes MyoD e Myf5 são absolutamente essenciais no 
estabelecimento e manutenção das linhagens miogênicas de células em todas as partes do corpo, assegurando a formação do tecido muscular esquelético mesmo na ausência de expressão de um destes genes, indicando que tais fatores apresentam funções redundantes (Rudnicki et al., 1993), apesar da distinta expressão temporal nos somitos e em outras regiões.

\section{Miogenina}

Camundongos homozigotos mutantes para o gene da miogenina produzem populações normais de mioblastos, mas a diferenciação terminal destes (i.e., formação de músculos funcionais), é ausente. Estes animais nascem imóveis e morrem logo após o nascimento, apresentam malformação das costelas e massa muscular reduzida, resultante da drástica redução da densidade de miofibras, e do grande número de células mononucleadas substituindo a maioria das células musculares maduras (Hasty et al., 1993; Nabeshima et al., 1993).

Após o nascimento, o número total de núcleos em regiões de formação de músculo parece ser o mesmo tanto em homozigotos mutantes como nos tipos selvagens. Entretanto, a maior parte dos genes músculo-específicos não são expressos em mutantes, sugerindo que estes núcleos representam mioblastos indiferenciados, uma vez que expressam níveis normais de $\mathrm{MyoD}$, indicando que a expressão deste é inteiramente independente da expressão da miogenina. Em contraste, a miogenina exerce grande influência sobre a ativação do MRF4, cuja expressão é reduzida em homozigotos mutantes. Sendo assim, a ausência de células musculares diferenciadas pode não estar relacionada unicamente com a ausência da miogenina nos indivíduos mutantes, mas também com a reduzida expressão de MRF4 (Arnold \& Braun, 2000).

Estas observações indicam que embora as células sejam capazes de entrar no programa miogênico na ausência de miogenina, são incapazes de se diferenciar e ativar a maior parte dos genes musculares sarcoméricos, sugerindo que a miogenina afeta de forma mais severa a miogênese secundária do que a miogênese primária (Arnold \& Braun, 2000). 


\section{MRF4}

De maneira geral, a ausência de MRF4 causa um fenótipo muscular muito suave, caracterizado por uma pequena redução na expressão de genes músculos-específicos (Patapoutian et al., 1995; Braun and Arnold, 1995; Zhang et al., 1995). Contudo, os fenótipos dos camundongos mutantes obtidos independentemente em três laboratórios apresentaram-se bastante variáveis, em função do tipo de mutação causada.

O alelo mutante gerado por Patapoutian et al., 1995, resultou na morte perinatal dos camundongos, os quais apresentaram severos problemas respiratórios devido à malformação das costelas. Entretanto, a anomalia não se apresentou tão aguda quando comparada aos camundongos mutantes Myf5 nulos.

A inativação do MRF4 no experimento realizado por Braun \& Arnold (1995), aparentemente afetou a transcrição do gene Myf5, que se localiza próximo ao MRF4 no mesmo cromossomo. Neste caso os resultados foram equivalentes aos dos mutantes Myf5 nulos. Contudo, apesar da ausência de MRF4 e da redução dos níveis de Myf5, estes animais desenvolveram musculatura normal, manifestando apenas uma moderada redução dos músculos das costas.

A linha de mutantes MRF4 nulos, gerada por Zhang et al. 1995, resultou em camundongos viáveis, porém com múltiplas anormalidades nas costelas, incluindo bifurcações e fusões. $\mathrm{Na}$ fase adulta os camundongos apresentaram músculos relativamente normais, mas expressaram níveis elevados de miogenina. Com isso, os autores sugeriram que o MRF4 é requerido para a redução da expressão da miogenina, que normalmente ocorre após o nascimento, atuando como um regulador negativo e que, portanto, o aumento da expressão da miogenina em indivíduos mutantes, poderia estar compensando a sua ausência.

\subsection{Miostatina}

A miostatina foi inicialmente descrita por McPherron et al. (1997) como um novo membro família TGF- $\beta$, que é expressa durante o desenvolvimento da musculatura 
esquelética em embriões e na fase adulta. A superfamília beta de fatores transformantes e de crescimento (TGF- $\beta$ ), é composta por um grande número de fatores de crescimento, os quais estão envolvidos na regulação de muitos processos celulares, tais como: proliferação, diferenciação e adesão celular (Capdevila \& Izpisuá Belmonte, 1999). Inúmeras pesquisas têm demonstrado que os fatores TGF- $\beta$ são potentes inibidores da diferenciação miogênica, importantes para a regulação do desenvolvimento embrionário e manutenção da homeostase dos tecidos em animais adultos (Thomas et al., 2000).

A miostatina compartilha várias propriedades estruturais com os demais membros da superfamília TGF- $\beta$ : um domínio central de aminoácidos hidrofóbicos próximo à extremidade amino-terminal, incluindo uma seqüência sinal para secreção; um sítio de processamento proteolítico conservado (RSRR); e nove resíduos de cisteína na região carboxi-terminal (McPherron, et al., 1997).

O gene da miostatina, também conhecido como GDF8 (Growth Differentiation factor 8), está localizado no cromossomo 7 da galinha e sua seqüência completa incluindo a região promotora, três exons e dois introns, está disponível no banco de dados do NCBI (acessos AF346599 e GeneID-373964). Assim como a maior parte dos membros da família TGF- $\beta$, a miostatina se apresenta altamente conservada sendo que genes homólogos têm sido encontrados em todos os vertebrados estudados incluindo humanos, camundongos e aves (McPherron \& Lee, 1997).

A função biológica da miostatina foi determinada pela sua inativação em camundongos, em que os indivíduos mutantes apresentaram um grande aumento da massa muscular esquelética devido à hiperplasia e hipertrofia da célula muscular, sugerindo que este gene estaria atuando como um potente regulador negativo do crescimento muscular esquelético, inibindo a proliferação de mioblastos (McPherron et al., 1997). Outras evidências que contribuíram para a caracterização da sua função biológica foram a descoberta de mutações na seqüência codificada pelo gene da miostatina em bovinos das raças Belgian Blue e Piamontesa, as quais foram relacionadas com o aumento da massa muscular. Estas mutações resultavam em uma proteína não funcional levando a um fenótipo caracterizado como musculatura dupla 
(McPherron \& Lee, 1997; Grobet et al., 1997).

A expressão do gene da miostatina é verificada inicialmente em células precursoras miogênicas localizadas no compartimento do miótomo de somitos em desenvolvimento, e sua expressão permanece na fase adulta em músculos axiais e paraxiais (McPherron et al., 1997; Mott \& Ivarie, 2002; Castelhano-Barbosa, 2001). Em aves, Castelhano-Barbosa (2001) detectou sinais de expressão desde o estágio HH1 (ovo recém-posto) até o estágio $\mathrm{HH} 25$ (embriões com 5 dias) e no tecido muscular peitoral de animais com 14 dias.

Embora os primeiros relatos descrevam a expressão da miostatina como exclusiva do músculo esquelético, publicações mais recentes têm mostrado a presença de transcritos ou proteínas em outros tecidos. Um estudo realizado com anticorpos miostatina-específicos indicou a presença da proteína em cardiomiócitos e fibras Purkinje do coração (Sharma et al. 1999), e de transcritos na glândula mamária (Ji et al., 1998). 


\section{MATERIAL E MÉTODOS}

\subsection{Formação da população referência}

\subsubsection{Linhagens}

Foram utilizadas duas populações experimentais de aves desenvolvidas pela Embrapa - Suínos e Aves, sendo uma de corte (TT) e outra de postura (CC). Estas linhagens apresentam composições genéticas distintas, pois a linhagem de corte teve sua origem a partir do cruzamento das raças Cornish, Hampshire e Plymouth Rock, enquanto que a linhagem de postura foi originada da raça White Leghorn. Estas linhagens foram selecionadas por várias gerações para diferentes objetivos.

A linhagem TT é uma linha macho, cuja seleção foi efetuada dentro de linha desde 1985, com o objetivo de melhorar geneticamente o potencial para: peso corporal, conversão alimentar, consumo de ração, rendimentos de carcaça e partes, viabilidade, fertilidade, eclodibilidade, redução da gordura abdominal e doenças metabólicas. $\mathrm{Na}$ época em que a população experimental foi formada esta linhagem já havia sido selecionada por seis gerações.

A linhagem CC foi selecionada por oito gerações desde 1989, para as características de: produção de ovos, peso do ovo, redução do peso corporal, conversão alimentar, viabilidade, maturidade sexual, fertilidade, eclodibilidade e qualidade do ovo. 


\subsubsection{Formação da geração F1 e F2}

A geração F1 foi formada a partir do acasalamento de sete machos TT com sete fêmeas $\mathrm{CC}$, havendo também o cruzamento recíproco de sete machos $\mathrm{CC}$ com sete fêmeas TT. O cruzamento foi feito através de inseminação artificial, na proporção de um macho para uma fêmea. As aves foram mantidas em gaiolas individuais para controle de pedigree, e os ovos identificados para possibilitar o anelamento dos pintos da geração F1 ao nascer.

A geração F1 inclui sete famílias oriundas do cruzamento TC e sete do cruzamento CT. Dentro de cada família, foram escolhidos ao acaso, três machos e seis fêmeas, os quais foram criados como matrizes de frango de corte e alojadas em gaiolas individuais.

$\mathrm{Na}$ fase de reprodução, foram selecionados ao acaso um macho e três fêmeas de cada uma das famílias da geração F1. O cruzamento foi feito na proporção de um macho para cada três fêmeas (não parentes próximos), através de inseminação artificial, para formação da geração F2. Um total de 7 machos e 21 fêmeas F1 de cada cruzamento geraram cerca de 100 pintos F2 por família F1, totalizando 4000 aves, sendo cerca de 2000 por tipo de cruzamento (TT x CC e CC x TT). Os pintos F2 foram obtidos em 17 incubações com intervalos de 15 dias durante quase oito meses.

Na geração F2 as aves foram identificadas por anéis, com controle de pedigree individual e avaliadas para várias características de crescimento e carcaça. Estas aves foram criadas como frangos de corte recebendo ração e água à vontade. Os animais receberam ração de crescimento ( $20 \%$ de Proteína Bruta e $3200 \mathrm{kcal}$ de Energia Metabolizável) e ração final de 36 a 41 dias (18,5\% de Proteína Bruta e 3.200kcal de Energia Metabolizável). As rações à base de milho e farelo de soja foram formuladas para atender às necessidades nutricionais das aves. As aves foram mantidas em boxes coletivos até 35 dias de idade, quando cada ave foi pesada e alojada em gaiola individual para teste de conversão alimentar dos 35 aos 41 dias. 
Devido ao tempo e aos custos demandados neste projeto, optou-se pela realização das análises moleculares somente em indivíduos do cruzamento TC. $\mathrm{Na}$ tabela 3 é apresentada a estrutura populacional do cruzamento TC.

Tabela 3. Estrutura populacional do cruzamento TC

\begin{tabular}{lccc}
\hline Geração & Machos & Fêmeas & Total \\
\hline Parental & 7 & 7 & 14 \\
F1 & 7 & $20^{\mathrm{a}}$ & 27 \\
F2 & 1039 & 1024 & 2063 \\
\hline
\end{tabular}

${ }^{\mathrm{a}}$ Houve perda por morte de uma fêmea F1.

\subsection{Dados fenotípicos coletados}

Os dados fenotípicos coletados referentes às características de desempenho foram: peso ao nascer (PN), peso vivo aos 35 (PV35), 41 (PV41) e 42 (PV42) dias de idade. Os dados de PV42 foram obtidos após 6 horas de jejum e transporte para o abate. Foram avaliados também: o ganho de peso (GP), consumo de ração (CR) e conversão alimentar (CA) dos 35 aos 41 dias de idade. Após o abate as aves foram submersas em água quente para facilitar a depena. As carcaças foram evisceradas e o peso de pulmão (PU), coração (COR), moela (MO) e comprimento do intestino (CI) foram avaliados.

As características de carcaça foram avaliadas após o resfriamento de 4 horas. Foram avaliados: o peso da carcaça (CARC - peso da carcaça sem vísceras, pés e cabeça), peso do peito (PP), coxas (PC - peso de coxas e sobre-coxas), peso da carcaça residual (CARR - peso da carcaça menos peso de peito, asas e coxas), asa (PA), gordura abdominal (GA) e pés (PÉS). Todos os dados fenotípicos obtidos estão armazenados em um banco de dados do setor de melhoramento de aves da EMBRAPA, para realização de diversos estudos de genes candidatos e mapeamento de QTL. 


\subsection{Extração de DNA}

As amostras de DNA genômico, dos parentais e das gerações F1 e F2, foram extraídas de sangue utilizando o reagente DNAzol ${ }^{\circledR}$ (Invitrogen). Para tanto, $1 \mathrm{ml}$ de DNAzol $^{\circledR}$ foi adicionado a alíquotas de $15 \mu \mathrm{L}$ de sangue conservado em EDTA. Após agitar manualmente as amostras por alguns segundos, o conteúdo foi fracionado em dois tubos. A cada tubo foram acrescentados $500 \mu \mathrm{L}$ de DNAzol ${ }^{\circledR}$, procedendo-se homogeneização e nova subdivisão do conteúdo em outros dois tubos. Foram adicionados $500 \mu \mathrm{L}$ de etanol absoluto, invertendo-se cuidadosamente cada amostra. $\mathrm{O}$ DNA precipitado foi coletado com o auxílio de um micropipetador e transferido para um tubo limpo. A seguir, foram feitas duas lavagens adicionais com $1 \mathrm{ml}$ de etanol 95\%, seguindo-se centrifugação a 1000 x $g$ por 10 min entre as lavagens. Na última lavagem, o sobrenadante foi descartado, e o pellet seco por duas horas a $37^{\circ} \mathrm{C}$. As amostras de DNA foram ressuspendidas em $300 \mu \mathrm{L}$ de TE ou água.

\subsection{Leitura no espectrofotômetro}

As amostras individuais de DNA foram analisadas em espectrofotômetro (HITACHI U-2000) e submetidas à eletroforese em gel de agarose 1,0\%. Após a confirmação da integridade procederam-se diluições, com base na concentração inicial calculada, para obter homogeneidade de concentração entre as amostras $(20 \mathrm{ng} / \mu \mathrm{l})$. Após a diluição, as amostras foram novamente submetidas à eletroforese em gel de agarose $1,0 \%$ para confirmação da homogeneidade.

\subsection{Detecção de polimorfismos}

\subsubsection{Preparação dos pools de DNA}

Foram preparados dois pools de DNA, cada um contendo quantidades equivalentes de DNA dos 14 parentais TT e CC de cada um dos cruzamentos. Desta 
forma, nos pools de DNA estavam igualmente representados os alelos dos indivíduos das respectivas linhagens, que na etapa seguinte foram utilizados como moléculas molde para as PCRs.

\subsubsection{PCR}

Aproximadamente $100 \mathrm{ng}$ de DNA do pool TT (ou CC) foram utilizados em cada reação de PCR. O volume final das reações foi de $50 \mu$, contendo 5 pmoles de cada um dos primers direto e reverso, $200 \mu \mathrm{M}$ de cada um dos dNTPs e $2 \mathrm{U}$ da DNA polimerase ThermalAce (Invitrogen). O tamanho dos produtos amplificados na reação de PCR e a seqüência dos primers utilizados na amplificação de cada gene são apresentados na tabela 4 .

Tabela 4. Seqüência dos primers utilizados nas PCRs e tamanho dos produtos resultantes da amplificação

\begin{tabular}{|c|c|c|}
\hline Gene & Seqüência dos primers & $\begin{array}{l}\text { Tamanho do } \\
\text { produto }\end{array}$ \\
\hline Miostatina & $\begin{array}{l}\text { DIRETO: 5' - AGTAGCGATGGCTCTTTGGA - 3' } \\
\text { REVERSO: 5' - CTGGGAATGTGACAGCAAGA - 3' }\end{array}$ & $2517 \mathrm{pb}$ \\
\hline MRF4 & $\begin{array}{l}\text { DIRETO: 5'- AGGACAAAATGCAGGAGG - 3' } \\
\text { REVERSO: 5'- GGTGGTCTGTGGGTCAAAAC - 3' }\end{array}$ & $742 \mathrm{pb}$ \\
\hline Myf5 & $\begin{array}{l}\text { DIRETO: 5'- GGTACATCGAAAGCCTCCAG - 3' } \\
\text { REVERSO: 5'- CTCATAGCGCCTGGTAGGTC - 3' }\end{array}$ & $800 \mathrm{pb}$ \\
\hline MyoD & $\begin{array}{l}\text { DIRETO: 5'- TACCCAGTGCTGGAGCACTA - 3', } \\
\text { REVERSO: 5'- GTCTTGGAGCTTGGCTGAAC - 3' }\end{array}$ & $2100 \mathrm{pb}$ \\
\hline Miogenina & $\begin{array}{l}\text { DIRETO: 5'- AGGCTGAAGAAGGTGAACGA - 3' } \\
\text { REVERSO: 5'- CACAGTGTCGGAGGGGTAAT - 3' }\end{array}$ & $\sim 3000 \mathrm{pb}$ \\
\hline
\end{tabular}


Para a amplificação dos genes Myf5 e MRF4 foi feita uma desnaturação inicial durante $3 \min \left(95^{\circ} \mathrm{C}\right)$, seguindo-se $1 \mathrm{~min}$ a $55^{\circ} \mathrm{C}$ e $1 \min$ a $74^{\circ} \mathrm{C}$. Nos 29 ciclos subseqüentes, o tempo de desnaturação foi reduzido para 1 minuto, mantendo-se as temperaturas e os tempos de anelamento e extensão, exceto no último ciclo, no qual foi feita uma extensão mais longa (15 min). As condições para amplificação do fragmento de MyoD, miostatina e miogenina foram distintas das empregadas para os outros genes. Primeiramente foi realizada uma desnaturação por 3 min a $94^{\circ} \mathrm{C}$, seguindo-se ciclos compostos por $40 \mathrm{~s} \mathrm{a} 94^{\circ} \mathrm{C}, 40 \mathrm{~s}$ a $62^{\circ} \mathrm{C}$ e $30 \mathrm{~s}$ a $72^{\circ} \mathrm{C}$.

\subsubsection{Clonagem e seqüenciamento dos produtos de PCR}

Após a amplificação, os produtos de PCR foram visualizados em gel de agarose e eluídos com o auxílio do Sephaglas Band Prep Kit (Amersham-Pharmacia). Foi realizada a clonagem dos fragmentos isolados em pSport/E.coli DH5 $\alpha$ com o Topo Cloning Kit (Invitrogen), conforme protocolo fornecido pelo fabricante.

Os clones TT e CC foram seqüenciados utilizando os primers universais M13 direto e reverso com o ABI Prism BigDye Terminator Kit (Applied Biosystems), no seqüenciador automático ABI 3100 (Applied Biosystems). Com isso, os fragmentos clonados de cada gene foram seqüenciados no sentido 5' - 3' e 3' - 5'.

\subsubsection{Análise das seqüências}

As seqüências foram editadas para a remoção da seqüência do vetor da extremidade 5', bem como para eliminar os nucleotídeos de baixa qualidade da extremidade 3'. Os programas Phred, Cap3 e Consed (Ewing \& Green, 1998; Huang \& Madan, 1999; Gordon, 1998) foram usados para a verificação da qualidade das bases, montagem e visualização dos contigs respectivamente. As seqüências dos clones TT e CC foram alinhadas com os programas ClustalW e/ou Cap3 (Huang e Madan, 1999) para identificação dos polimorfismos. 
No intuito de dinamizar o processo de detecção de polimorfismos, recentemente foi desenvolvido no Laboratório de Biotecnologia Animal - ESALQ/USP, um sistema automático, o qual realiza o alinhamento, clusterização, Blastn e identificação de polimorfismos pontuais, disponibilizando uma tabela com a localização e descrição de cada um dos polimorfismos, em seqüências com qualidade maior ou igual a 20. Neste sistema, as seqüências dos clones de cada gene foram submetidas pela rede, depositadas em um banco de dados e finalmente reanalisadas quanto à qualidade pelo programa Phred e alinhadas pelo programa Cap3.

\subsection{Escolha dos polimorfismos e desenho de primers para genotipagem}

Os primers foram desenhados com base nos contigs obtidos pelo alinhamento das seqüências dos clones TT e CC para todos os genes exceto para o gene MyoD, cujos primers foram desenhados a partir da seqüência completa do gene disponível no banco de dados do NCBI (tabela 5). As regiões flanqueadas por estes primers foram escolhidas segundo a densidade e freqüência de polimorfismos detectados e/ou presença de SNPs não sinônimos.

Para o desenho de primers foi utilizado o programa Primer3Input (http://wwwgenome.wi.mit.edu/cgi-bin/primer/primer3_www.cgi). Alguns dos primers listados já se encontravam disponíveis no Laboratório de Biotecnologia. 
Tabela 5. Seqüência dos primers desenhados e testados para a genotipagem

\begin{tabular}{|c|c|c|}
\hline Gene & Seqüência dos primers & Identificação \\
\hline \multirow[t]{3}{*}{ Miostatina } & DIRETO: 5'-TGCATCCACTCTGTTACCAA - 3' & MST2D \\
\hline & DIRETO: 5' - TTCTTTTTGTTCCCTGTTCAGT- 3' & MST2DS \\
\hline & REVERSO: 5'- CTGCCATTCTCGAAGCAATA - 3' & MST2R \\
\hline \multirow{2}{*}{ Miogenina } & DIRETO: 5' - AGGCTGAAGAAGGTGAACGA - 3' & PD 300 \\
\hline & REVERSO: 5'-CACAGTGTCGGAGGGGTAAT - 3; & R10 \\
\hline \multirow[t]{3}{*}{ MyoD } & DIRETO: 5'- ACTGGAGAGATGCCTGATGG - 3' & PDMyoD3 \\
\hline & DIRETO: 5'- ATCTGCCCTCCCTGAATAGC - 3' & PDSMyoD2 \\
\hline & REVERSO: 5'- GTCTTGGAGCTTGGCTGAAC - 3' & PRMyoD \\
\hline \multirow[t]{6}{*}{ MRF4 } & DIRETO: 5' - AGGACAAAATGCAGGAGGTG - 3' & PD472/4 \\
\hline & REVERSO: 5' - GAGAGAGGGGTTAGGGAACG - 3' & MRF2S \\
\hline & REVERSO: 5'- GAGGAAATGCTGTCCACGAT- 3' & MRF1R \\
\hline & DIRETO: 5' - AGGCTGGATCAGCAGGACAA - 3' & PDMRF4 \\
\hline & REVERSO: 5'- CTCATTTCTCCACCGCCTCT - 3' & PRMRF4 \\
\hline & REVERSO: 5'- GGTGGTCTGTGGGTCAAAAC - 3' & PR872/4 \\
\hline \multirow[t]{8}{*}{ Myf5 } & REVERSO: 5' - GGTACATCGAAAGCCTCCAG- 3' & PR1322/5 \\
\hline & DIRETO: 5' - CTCATAGCGCCTGGTAGGTC- 3' & $\mathrm{PD} 523 / 5$ \\
\hline & REVERSO: 5' - TGGTAGCACGCTTTATTTGC - 3' & PR1522/5 \\
\hline & DIRETO: 5'- CTGCTCCGATGTGATGGTAA - 3' & $\mathrm{PD} 623 / 5$ \\
\hline & DIRETO: 5'- ATGTTGGACGGTTTGGGTTC - 3' & PDSMyf5 \\
\hline & REVERSO: 5' - ACGATGCTGGAGAGGCAGTC - 3' & PRMyf5 \\
\hline & REVERSO: 5' - TCATAGCGCCTGGTAGGTCC - 3' & PRMyf5H \\
\hline & DIRETO: 5'- TCCAGCTGCTCCGATGTGAT - 3' & PDMyf5 \\
\hline
\end{tabular}

\subsection{Otimização da PCR}

Três diferentes metodologias foram utilizadas para otimização das reações em decorrência das dificuldades encontradas nesta etapa do projeto. O programa do termociclador utilizado nesta etapa é apresentado na tabela 6 . 
Tabela 6. Programa utilizado nos termocicladores para otimização da PCR

\begin{tabular}{ccl}
\hline Passos & Temperatura & Tempo \\
\hline 1 & $92^{\circ} \mathrm{C}$ & 3 minutos \\
2 & $92^{\circ} \mathrm{C}$ & 1 minuto \\
3 & $45-65^{\circ} \mathrm{C}$ & 1 minuto \\
4 & $72^{\circ} \mathrm{C}$ & 1 minuto \\
5 & - & voltar ao passo 2 (29 vezes) \\
6 & $72^{\circ} \mathrm{C}$ & 10 minutos \\
7 & $4{ }^{\circ} \mathrm{C}$ & indefinidamente \\
\hline
\end{tabular}

As otimizações das reações foram realizadas inicialmente com o PCR Optimizer Kit (Invitrogen). Porém, as reações cujos primers não apresentaram resultados satisfatórios dentro das condições testadas pelo kit comercial, foram otimizadas por meio de testes de gradiente de temperatura e concentração de $\mathrm{MgCl}_{2}$ com os tampões $10 \mathrm{X}$ e soluções de $\mathrm{MgCl}_{2}$ comerciais, adquiridos juntamente com a Taq DNApolimerase.

O PCR Optimizer Kit utilizado na otimização da amplificação é constituído por tampões com concentrações de magnésio e pH diferentes, sendo que todos os tampões têm em comum 300 mM de Tris- $\mathrm{HCl}$ e $75 \mathrm{mM}$ de Sulfato de Amônio. O kit contém ainda dNTP mix na concentração de $2,5 \mathrm{mM}$ para cada nucleotídeo dentre outros componentes.

Os pares de primers de todos os marcadores foram testados com os tampões A, $\mathrm{B}, \mathrm{C}, \mathrm{D}, \mathrm{F}, \mathrm{J}$ e N, referentes ao primeiro passo do protocolo do kit e com os demais tampões referentes ao segundo passo do protocolo, caso a otimização não tenha sido alcançada no primeiro passo (tabela 7). 
Tabela 7. Conteúdo dos tampões 5X do PCR Optimizer Kit (Invitrogen)

\begin{tabular}{llc}
\hline Item & Composição & [ ] $\mathrm{MgCl}_{2}$ na reação \\
\hline Tampão A 5X & $\mathrm{MgCl}_{2} 7,5 \mathrm{mM}, \mathrm{pH} \mathrm{8,5}$ & $1,5 \mathrm{mM}$ \\
Tampão B 5X & $\mathrm{MgCl}_{2} 10 \mathrm{mM}, \mathrm{pH} 8,5$ & $2,0 \mathrm{mM}$ \\
Tampão C 5X & $\mathrm{MgCl}_{2} 12,5 \mathrm{mM}, \mathrm{pH} 8,5$ & $2,5 \mathrm{mM}$ \\
Tampão D 5X & $\mathrm{MgCl}_{2} 17,5 \mathrm{mM}, \mathrm{pH} 8,5$ & $3,5 \mathrm{mM}$ \\
Tampão E 5X & $\mathrm{MgCl}_{2} 7,5 \mathrm{mM}, \mathrm{pH} 9,0$ & $1,5 \mathrm{mM}$ \\
Tampão F 5X & $\mathrm{MgCl}_{2} 10 \mathrm{mM}, \mathrm{pH} 9,0$ & $2,0 \mathrm{mM}$ \\
Tampão G 5X & $\mathrm{MgCl}_{2} 12,5 \mathrm{mM}, \mathrm{pH} 9,0$ & $2,5 \mathrm{mM}$ \\
Tampão H 5X & $\mathrm{MgCl}_{2} 17,5 \mathrm{mM}, \mathrm{pH} 9,0$ & $3,5 \mathrm{mM}$ \\
Tampão I 5X & $\mathrm{MgCl}_{2} 7,5 \mathrm{mM}, \mathrm{pH} \mathrm{9,5}$ & $1,5 \mathrm{mM}$ \\
Tampão J 5X & $\mathrm{MgCl}_{2} 10 \mathrm{mM}, \mathrm{pH} 9,5$ & $2,0 \mathrm{mM}$ \\
Tampão K 5X & $\mathrm{MgCl}_{2} 12,5 \mathrm{mM}, \mathrm{pH} 9,5$ & $2,5 \mathrm{mM}$ \\
Tampão L 5X & $\mathrm{MgCl}_{2} 17,5 \mathrm{mM}, \mathrm{pH} \mathrm{9,5}$ & $3,5 \mathrm{mM}$ \\
Tampão M 5X & $\mathrm{MgCl}_{2} 7,5 \mathrm{mM}, \mathrm{pH} \mathrm{10}$ & $1,5 \mathrm{mM}$ \\
Tampão N 5X & $\mathrm{MgCl}_{2} 10 \mathrm{mM}, \mathrm{pH} \mathrm{10}$ & $2,0 \mathrm{mM}$ \\
Tampão O 5X & $\mathrm{MgCl}_{2} 12,5 \mathrm{mM}, \mathrm{pH} \mathrm{10}$ & $2,5 \mathrm{mM}$ \\
Tampão P 5X & $\mathrm{MgCl}_{2} 17,5 \mathrm{mM}, \mathrm{pH} \mathrm{10}$ & $3,5 \mathrm{mM}$ \\
\hline
\end{tabular}

Após a realização dos testes de tampão sob temperatura de anelamento de $55^{\circ} \mathrm{C}$, foram testadas outras temperaturas de anelamento, segundo protocolo do fabricante.

A otimização da PCR por gradiente de temperatura foi feita somente para alguns pares de primers, os quais não apresentaram resultados satisfatórios com a utilização do kit. Esta metodologia consistiu em submeter frações de uma mesma reação, contendo uma elevada concentração de $\mathrm{MgCl}_{2}$ pré-estabelecida, a um gradiente de temperatura com uma amplitude de $10^{\circ} \mathrm{C}$ a $20^{\circ} \mathrm{C}$ em relação à temperatura de anelamento calculada. Após o primeiro teste, mediante a ocorrência de amplificação de produtos inespecíficos, reações com menores concentrações foram novamente submetidas ao gradiente de temperatura.

Os produtos amplificados de cada gene foram visualizados em gel de agarose $1,0 \%$ e verificados quanto ao tamanho aproximado do produto, segundo a seqüência flanqueada pelos respectivos primers. O tamanho dos fragmentos amplificados foi determinado com a utilização do marcador de peso molecular $\phi x$ Hae III fragments e o programa Kodak 1D digital science v. 3.0.2. 


\subsection{Purificação pré-seqüenciamento dos produtos da PCR}

Otimizadas as condições da PCR, foram realizadas as amplificações e a purificação dos produtos, a qual consistiu na retirada dos resíduos de primers, dNTP e Taq DNApolimerase da reação, para obtenção de seqüências de melhor qualidade nos cromatogramas após o seqüenciamento.

Para esta finalidade, foi empregado o protocolo de precipitação com isopropanol: igual volume de isopropanol foi adicionado ao tubo de amostra seguindo-se 15 minutos de incubação a $25^{\circ} \mathrm{C}$. Posteriormente, a mistura foi centrifugada por 20 minutos na rotação máxima $(15000 \mathrm{rpm})$ e o sobrenadante descartado. Foram realizadas duas lavagens com $200 \mu \mathrm{l}$ de Etanol 75\%, sendo as amostras centrifugadas por 20 minutos em cada lavagem. Após descartar o sobrenadante o pellet foi seco em centrífuga à vácuo por 20 minutos, e então ressuspendido em $10 \mu \mathrm{l}$ de $\mathrm{H}_{2} \mathrm{O}$ deionizada.

As amostras purificadas foram visualizadas em gel de agarose 1,0\% para verificação da concentração final dos produtos de PCR.

\subsection{Seqüenciamento dos produtos de PCR}

Os produtos de PCR purificados foram seqüenciados utilizando-se os respectivos primers diretos da reação de PCR com o ABI Prism BigDye Terminator Kit (Applied Biosystems), no seqüenciador automático ABI 3100 (Applied Biosystems).

\subsection{Genotipagem}

Neste projeto optou-se por realizar o estudo de polimorfismos na população TC oriunda do cruzamento de machos TT e fêmeas CC. Para tanto, a genotipagem foi realizada em três fases: genotipagem da geração parental do cruzamento TC, para validação dos polimorfismos detectados; genotipagem seletiva da geração F2, para identificação dos polimorfismos de maior relevância; e genotipagem dos indivíduos F2 pertencentes às famílias informativas que apresentaram os polimorfismos de interesse. 
Os primers selecionados para a genotipagem e suas respectivas condições de PCR otimizadas estão descritos no Anexo A.

\subsubsection{Geração parental}

Visando validar os polimorfismos detectados nos clones, os parentais do cruzamento TC foram genotipados por seqüenciamento dos produtos de PCR. Esta genotipagem inicial permitiu não só a identificação dos alelos segregantes presentes na população, como também a identificação de novos polimorfismos.

\subsubsection{Genotipagem seletiva da geração F2}

Os testes preliminares de associação entre os polimorfismos identificados nos genes candidatos e os caracteres fenotípicos foram realizados pelo método conhecido como Selective Genotyping descrito por Lander e Botstein (1989), comumente aplicado para mapeamento de QTL. Neste modelo, a genotipagem é realizada somente em indivíduos cujos fenótipos desviam substancialmente da média dentro da população, para determinada característica. A análise de animais de desempenho extremo, desconsiderando-se àqueles cujo desempenho se encontra no meio da curva de distribuição da população, pode reduzir substancialmente o número de indivíduos genotipados, sem que com isso haja perda de uma porção significante da variância genética (Hillel, 1997).

Foi verificado que a característica de peso vivo aos 42 dias apresentou correlação fenotípica mais elevada com um maior número de características de desempenho e caracaça e portanto os animais foram selecionados segundo a distribuição desta característica. Para esta finalidade, foi realizada a revisão preliminar dos dados fenotípicos de todos os animais para correção de possíveis erros de digitação e descarte de valores discrepantes (outliers). Foram descartados também animais cujas amostras de sangue não estavam disponíveis. Com o objetivo de controlar os efeitos de sexo e ambientais, estes dados corrigidos foram agrupados de acordo com o sexo, e os valores 
de peso vivo aos 42 dias de cada grupo foram ajustados para o efeito de incubação. A seleção dos animais foi feita dentro de família no intuito de evitar que alguma família não fosse representada na amostragem. Desta forma, foram genotipados 170 animais F2 (9\% da população TC), incluindo 84 machos e 86 fêmeas, onde a proporção de animais selecionados nos extremos de cada família foi de 4,5\% dos animais mais leves e 4,5\% dos animais pesados, com uma variação de seis a dez animais por família.

A genotipagem seletiva dos indivíduos da F2 foi realizada com o objetivo de identificar os polimorfismos de maior relevância dentre os três genes, bem como selecionar todas as famílias informativas para análises futuras.

\subsubsection{Genotipagem dos indivíduos F2 das famílias informativas}

Para o estudo dos efeitos dos polimorfismos de cada gene, identificados na genotipagem seletiva, bem como dos efeitos de interação entre eles, foram selecionadas três famílias informativas para genotipagem. Para que os efeitos fixos de sexo e família fossem ajustados na análise estatística, foram genotipados 96 indivíduos, sendo 32 de cada família, dos quais metade eram machos e a outra metade eram fêmeas. Todos os animais foram genotipados por seqüenciamento.

\subsection{Análise Estatística}

\subsubsection{Teste $\chi^{2}$ (Qui-quadrado)}

As freqüências alélica e genotípica dos indivíduos dos grupos de leves e pesados, obtidas pela genotipagem seletiva, foram testadas pelo teste qui-quadrado, seguindo a equação:

$$
\chi^{2}=\sum_{i=1}^{r} \sum_{j=1}^{s} \frac{\left(F o_{i j}-F e_{i j}\right)^{2}}{F e_{i j}}
$$


em que $F O_{i j}$, é a freqüência observada na linha $i$, coluna $j ; F e_{i j}$ a freqüência esperada na linha $i$, coluna $j, r$ é o número de linhas e $s$, o número de colunas.

\subsubsection{Análise de Variância}

Foram incluídos na análise de variância os dados fenotípicos de desempenho: PN, PV35, PV41, PV42, GP, GP35, GP41, GP42, CA, EF, PU, COR, MO e CI; as características de carcaça CARC, PC, CARR, PA e GA. Foram incluídos também os dados gerados PPEIT (porcentagem de peito), PCARC (rendimento de carcaça), PGA (porcentagem de gordura abdominal), calculados a partir dos dados fenotípicos coletados.

As análises de variância para testar os efeitos de cada gene, bem como da interação entre eles foram feitas com o PROC GLM do SAS (SAS Intitute, 1996). A primeira análise de variância denominada de Single-gene Model foi realizada seguindo o modelo:

$$
Y_{i j k l}=\mu+I_{i}+S_{j}+F_{k}+G_{l}+e_{i j k l}
$$

Onde $Y_{i j k l}$ representa o valor fenotípico de cada caráter, $\mu$ representa a média, $I_{i}$ é o efeito de incubação, $S_{j}$, o efeito de sexo, $F_{k}$, o efeito de família, $G_{l}$ se refere ao efeito do genótipo de cada sítio polimórfico de cada gene e $e_{i j k l}$ o erro padrão.

Uma segunda análise de variância seguiu o modelo multigênico ou Multi-gene Model descrito por Bonvenhuis et al.(1992):

$$
Y_{i j k l m n}=\mu+I_{i}+S_{j}+F_{k}+\operatorname{Mstn}_{l}+\operatorname{Miog}_{m}+\operatorname{Myod}_{n}+e_{i j k l m n}
$$


em que $\operatorname{Mstn}_{l}, \operatorname{Miog}_{m}$ e $\operatorname{Myod}_{n}$ correspondem ao efeito de cada genótipo dos genes da miostatina, miogenina e MyoD, respectivamente.

Os modelos utilizados para a análise de variância foram ajustados para cada um dos caracteres estudados, para os quais foram testados os efeitos fixos de incubação, sexo, família e o efeito de interação entre estes. Nesta análise os efeitos fixos estatisticamente não significativos foram excluídos do modelo.

Os valores de probabilidade dos efeitos de genótipos gerados no teste quiquadrado e na análise de variância foram classificados como altamente significativos (**), quando $\mathrm{P}<0,01$, significativos $\left(^{*}\right)$, quando $\mathrm{P}<0,05$ e sugestivos $\left(^{\dagger}\right)$, quando $\mathrm{P}<0,10$. 


\section{RESULTADOS E DISCUSSÃO}

\subsection{Detecção de polimorfismos}

Todos os polimorfismos dos genes miostatina, miogenina, MRF4 e Myf5 foram detectados por meio do seqüenciamento dos produtos de PCR clonados, obtidos dos pools de DNA dos parentais das linhagens TT e CC de ambos os cruzamentos. Foram obtidas seqüências referentes tanto à extremidade 5' quanto à extremidade 3' do inserto Devido à baixa qualidade do seqüenciamento dos clones de MyoD, a detecção de polimorfismos neste gene foi realizada diretamente pelo seqüenciamento dos produtos de PCR dos 14 parentais do cruzamento TC.

Somente os polimorfismos com qualidade $\geq 40$ com freqüência acima de $1 \%$ ou que se localizavam em regiões de maior relevância no exon, foram classificados como SNPs. Isto foi feito no intuito de excluir da análise possíveis artefatos ocasionados por erros de incorporação de bases nas reações, bem como selecionar os polimorfismos de maior relevância para a etapa de genotipagem. Na tabela 8 é apresentado o número de SNPs detectados em clones das linhagens TT e CC. A descrição dos contigs e SNPs identificados estão nos Anexos B, C, D e E. 
Tabela 8. Número de contigs, reads e SNPs identificados em clones dos genes da miostatina, miogenina, MRF4 e Myf5

\begin{tabular}{lccccc}
\hline Gene & Contigs & $\mathrm{n}^{\mathbf{0}}$ de reads & TT & CC & Total \\
\hline Miostatina & 2 & 100 & 11 & 2 & 19 \\
Miogenina & 4 & 127 & 21 & 16 & 37 \\
MRF4 & 2 & 214 & 26 & 44 & 100 \\
Myf5 & 1 & 42 & 7 & 12 & 20 \\
\hline
\end{tabular}

Os contigs contendo a localização dos polimorfismos detectados pelo seqüenciamento dos produtos de PCR clonados do gene da miostatina estão representados nas figuras 4 e 5 .

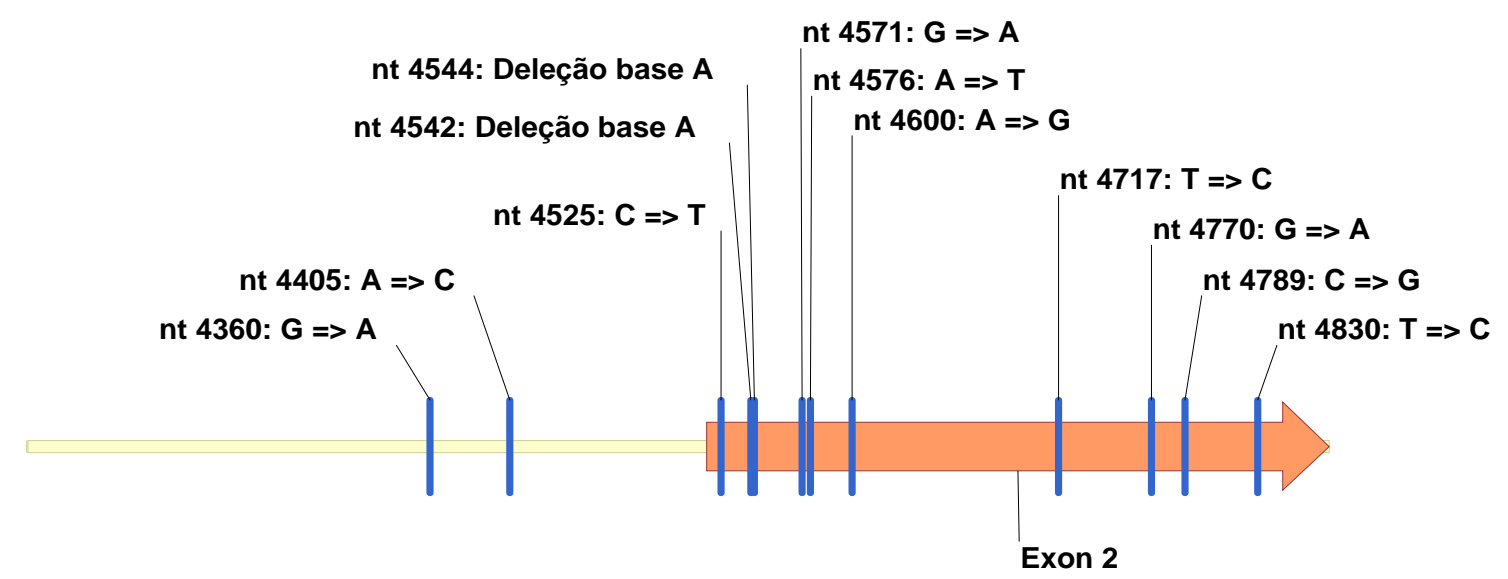

Contig 1 MSTN 3'

$739 \mathrm{bp}$

Figura 4 - Seqüência do contig 1 da miostatina com a localização dos polimorfismos detectados, segundo a numeração disponível no NCBI (acesso AF346599) 


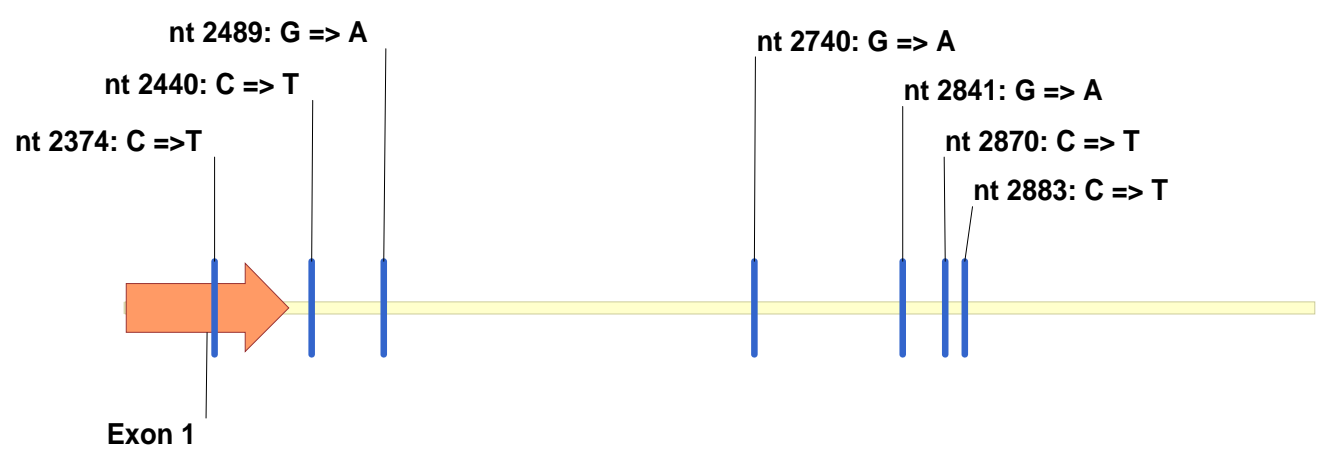

Contig 2 MSTN 5'

807 bp

Figura 5 - Seqüência do contig 2 da miostatina com a localização dos polimorfismos detectados (NCBI, acesso AF346599)

O seqüenciamento dos clones da miogenina gerou quatro contigs, dois referentes à extremidade $5^{\prime}$ e dois referentes à extremidade $3^{\prime}$ do inserto. Foi realizada uma nova montagem com as seqüências dos contigs 1 e 2, na qual foi possível identificar outros quatro polimorfismos, caracterizados por dois sítios de substituição $\mathrm{C}=>\mathrm{T}$ e dois sítios de deleção de oito pares de base. Foi verificado que todos estes sítios polimórficos fazem parte de um único alelo, o qual foi encontrado em todos os reads do contig 2. Entretanto, não foi possível inferir com precisão qual grupo de nucleotídeos estaria incluído no sítio de deleção, uma vez que há três diferentes montagens que podem ser editadas para localizar as deleções, como é mostrado na figura 6. 
Montagem 1

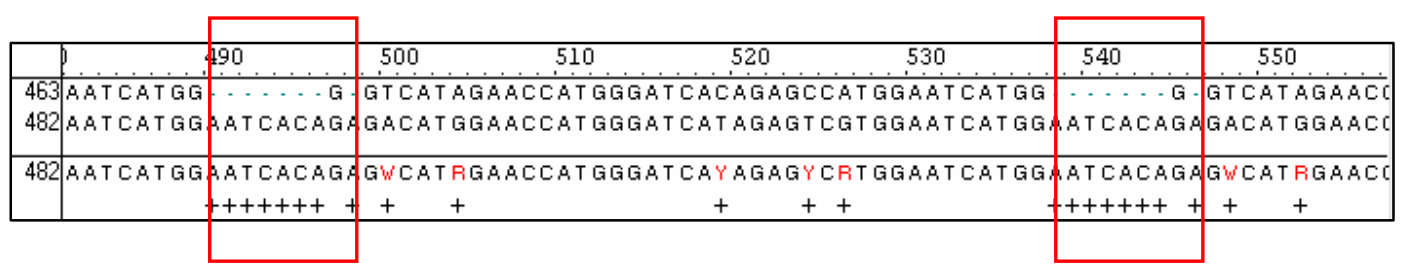

Montagem 2

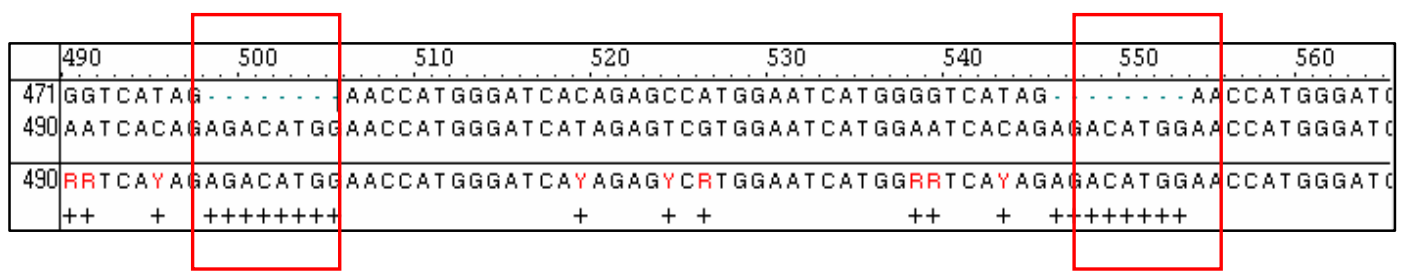

Montagem 3

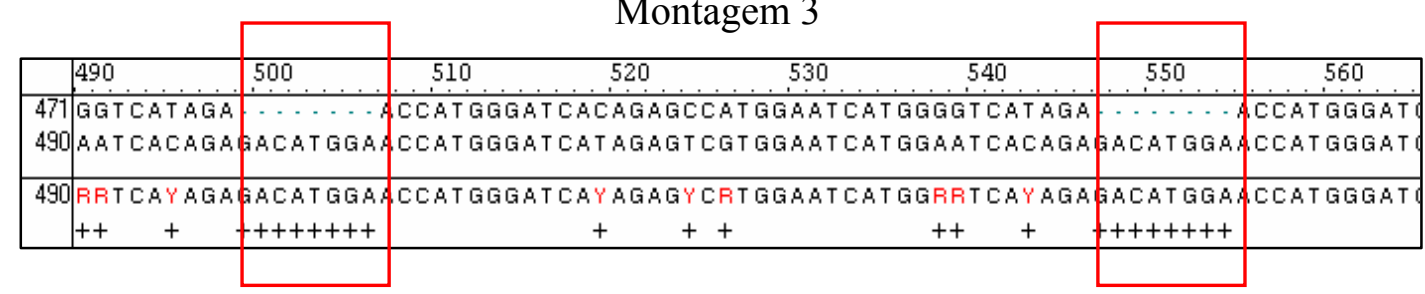

Figura 6 - Contigs formados pela remontagem das seqüências dos contigs 1 e 2 da miogenina

Segundo dados disponíveis no banco de dados de SNPs do NCBI este polimorfismo foi caracterizado como uma deleção/inserção da seqüêcia de nucleotídeos [AATCACA] (acesso rs15466457) e do nucleotídeo [A] (acesso rs15466460) como descrito na montagem 1 da figura 6 .

Os contigs contendo a localização dos polimorfismos detectados pelo seqüenciamento dos produtos de PCR clonados do gene da miogenina estão representados nas figuras 7 e 8 . 


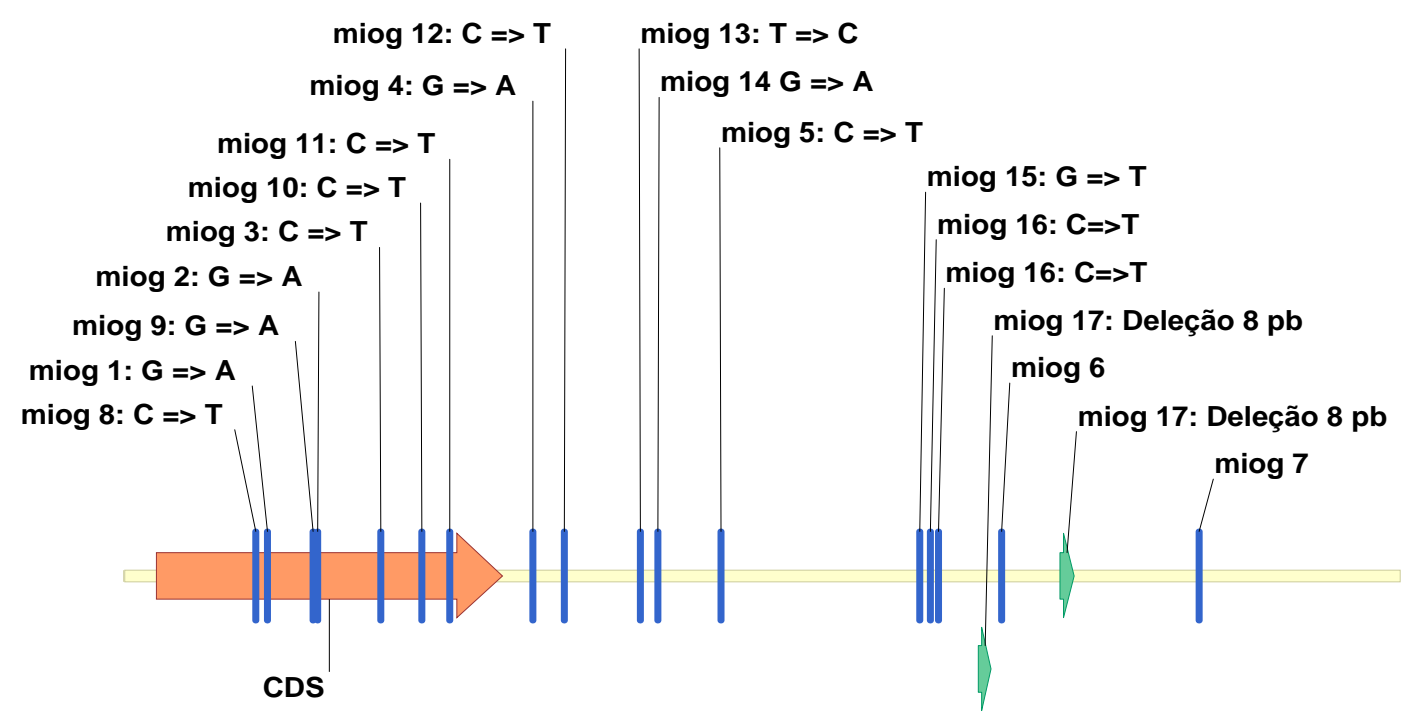

Contigs 1 e 2 MIOG 5'

$745 \mathrm{bp}$

Figura 7 - Polimorfismos detectados nos contigs 1 e 2 referentes à extremidade 5'. A região CDS foi localizada pelo alinhamento dos contigs com a seqüência disponível sob número de acesso D90157 no NCBI, realizada pelo programa Vector NTI 


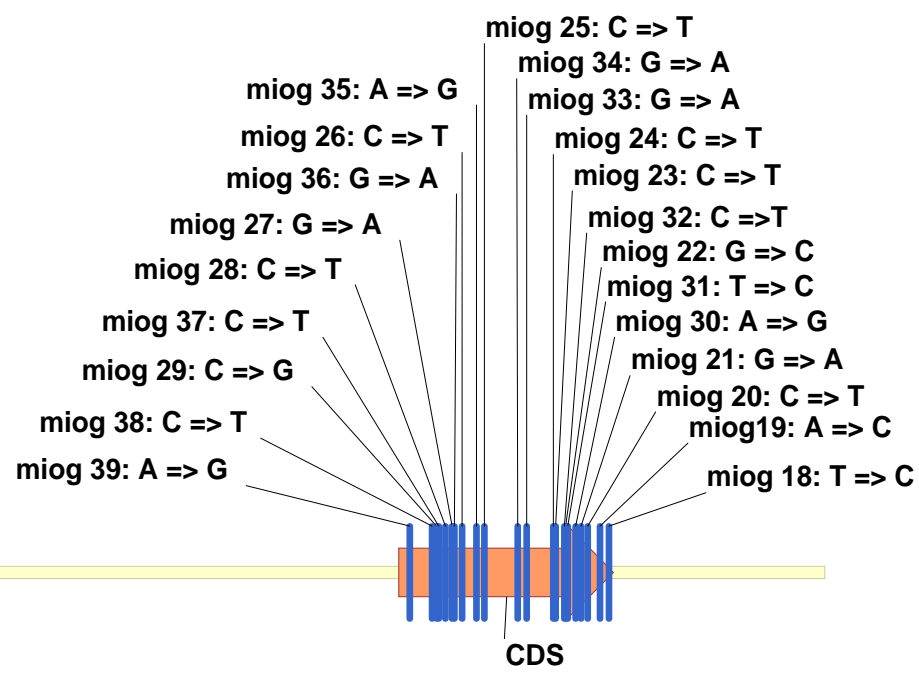

Contig 3 e 4 MIOG 3'

$706 \mathrm{bp}$

Figura 8 - Polimorfismos detectados nos contigs 3 e 4 referentes à extremidade 3'. A região CDS foi localizada pelo alinhamento dos contigs com a seqüência disponível sob acesso D90157 no NCBI, realizada pelo programa Vector NTI

Os contigs contendo os polimorfismos detectados no gene MRF4 não foram representados em figuras devido ao grande número de SNPs identificados os quais se apresentaram densamente distribuídos por todo o fragmento seqüenciado. $\mathrm{O}$ único contig obtido pelo seqüenciamento dos clones do gene Myf5 é apresentado na figura 9. 


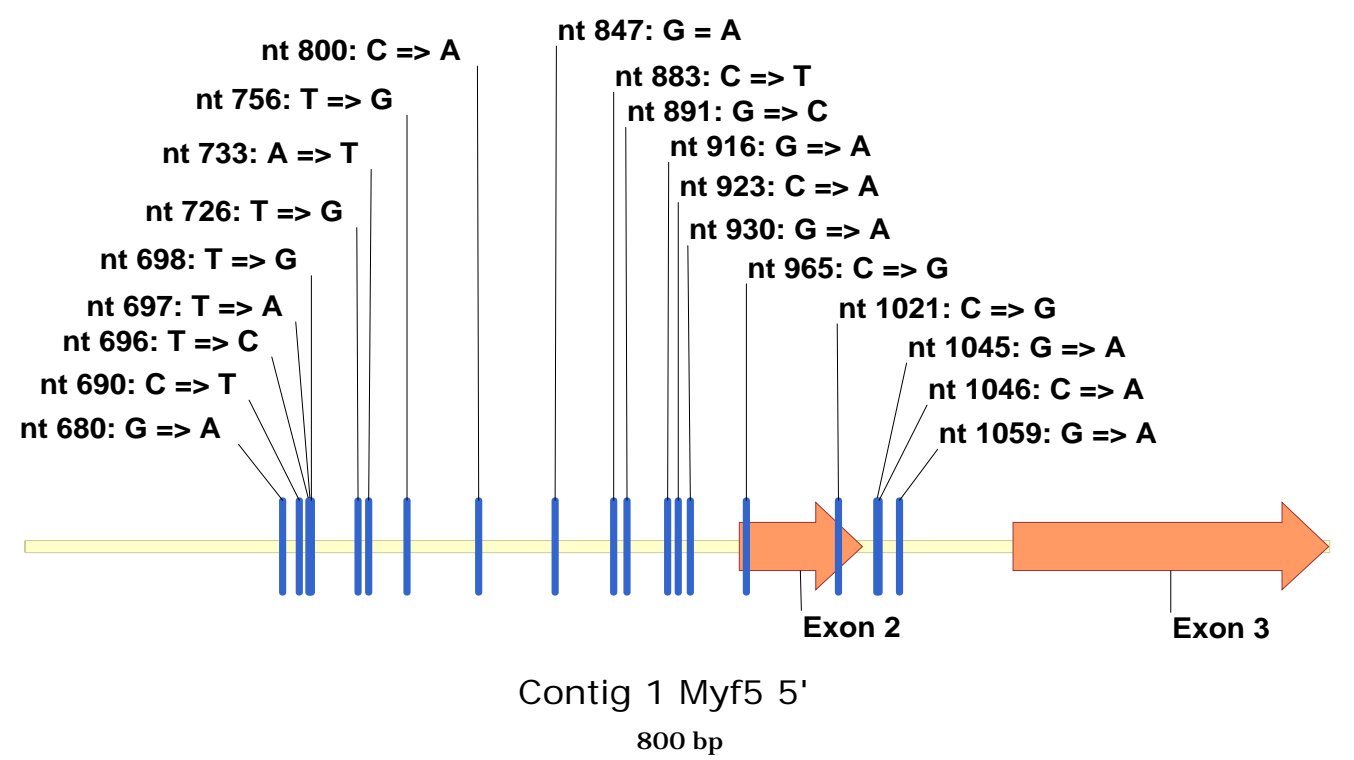

Figura 9 - Seqüência do único contig do gene Myf5 com a localização dos polimorfismos detectados (NCBI, acesso X73250)

Para a detecção de polimorfismos do gene MyoD foram utilizados o primer direto PDMyoD3 (5'-ACTGGAGAGATGCCTGATGG-3'), desenhado exclusivamente para genotipagem, e o reverso PRMyoD (5'- GTCTTGGAGCTTGGCTGAAC - 3'), utilizado na fase de clonagem. Estes primers amplificam um fragmento de 604 pares de base, o qual inclui uma região de 284 pares de base do intron 2 e 320 pares de base do exon 3.

$\mathrm{Na}$ geração parental foi possível detectar um polimorfismo caracterizado pela deleção de 13 pares de base [GGCATCCTTCACT], quando comparado à seqüência de MyoD disponível no NCBI pelo acesso L34006, incluindo os nucleotídeos 6619 a 6631. Foi verificado que somente os parentais da linhagem TT possuíam esta deleção, quatro em heterozigose e um em homozigose.

O fragmento amplificado inclui ainda, no exon 3, uma região microssatélite (regiões geralmente caracterizadas como seqüências de 1 a 4 nucleotídeos, repetidas em tandem). Este loco microssatélite denominado MYOD1 foi descrito por Moran (1993) e contém sete repetições consecutivas da seqüência AGC, a partir do $6970^{\circ}$ nucleotídeo. 
Esta região não se apresentou polimórfica entre os indivíduos genotipados. O gene MyoD está ilustrado na figura 10.

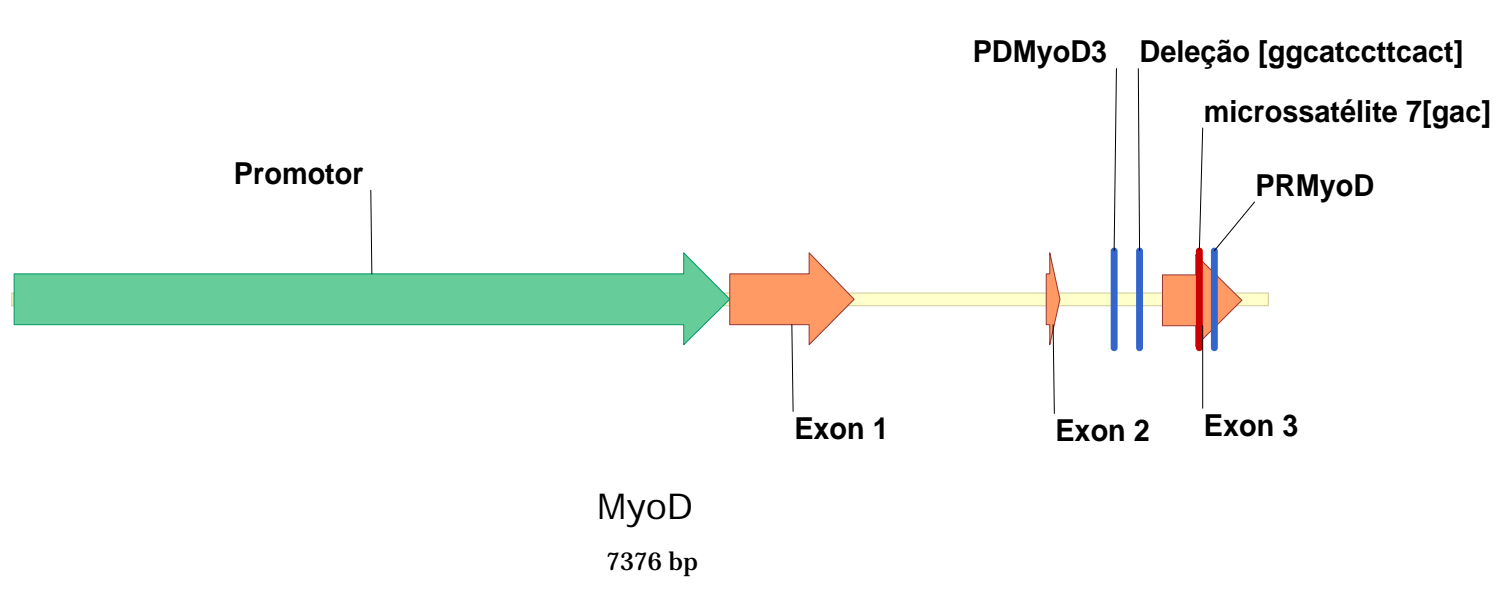

Figura 10 - Gene MyoD de Gallus gallus com a localização dos primers e do polimorfismo caracterizado pela deleção de 13 pares de base no intron 2

\subsection{Validação de polimorfismos}

A validação dos polimorfismos detectados nos clones foi realizada pela genotipagem por seqüenciamento dos produtos de PCR dos parentais do cruzamento TC. As regiões selecionadas para a validação dos polimorfismos para posterior genotipagem foram escolhidas com base na densidade e freqüência de polimorfismos detectados e/ou presença de SNPs não sinônimos.

\subsubsection{Miostatina}

Os primers selecionados nesta etapa amplificam todo o exon 2 e algumas bases adjacentes do intron 2, região que inclui 10 dos 19 sítios polimórficos de interesse detectados no seqüenciamento dos clones.

Na figura 11 está ilustrado o fragmento seqüenciado com a localização do único polimorfismo do tipo sinônimo encontrado nos parentais do cruzamento TC no intron 2 (acesso, AF346599). 
Intron 1

TGCATCCACTCTGTTACCAATACAGTTTATGTAATATTGTAAGACATCCTACATGATCTGGAAAAAA ATTGGGTTATATATGCATATTTCTTTTTGTTCCCTGTTCAGTAATTTGTTCTTTCCATTCATTTATAG $\underline{\underline{ }}$ TGATTTTCTTGTACAAATGGAGGGAAAACCAAAATGTTGCTTCTTTAAGTTTAGCTCTAAAATACAA

Exon 2 TATAACAAAGTAGTAAAGGCACAATTATGGATATACTTGAGGCAAGTCCAAAAACCTACAACGGT GTTTGTGCAGATCCTGAGACTCATTAAGCCCATGAAAGACGGTACAAGATATACTGGAATTCGATC TTTGAAACTTGACATGAACCCAGGCACTGGTATCTGGCAGAGTATTGATGTGAAGACAGTGCTGCA AAATTGGCTCAAACAGCCTGAATCCAATTTAGGCATCGAAATAAAAGCTTTTGATGAGACTGGACG

Intron 2 AGATCTTGCTGTCACATTCCCAGGACCGGGTGAAGATGGATTGGTAAGTTCATTAGAAAAATCTCA TTTAAATATCATTGGAAAGGGATTATGTTTAAAGGATAAAAATGGAAATATTGCTTCGAGAATGGC AG

Figura 11 - Localização do sítio polimórfico 4938 da miostatina: Substituição A => G, presente em parentais da linhagem CC

Neste fragmento, um único SNP no nucleotídeo 4938, caracterizado pela substituição de uma base A por uma base $\mathrm{G}$, foi identificado nestes indivíduos, sendo que o alelo $\mathrm{G}$ foi evidenciado em cinco parentais da linhagem CC. Para facilitar sua descrição neste trabalho, este polimorfismo foi denominado A4938G, uma vez que esta identificação descreve não só a sua posição nucleotídica como também caracteriza o polimorfismo como uma substituição $A=>$. $\mathrm{O}$ padrão dos cromatogramas para cada genótipo A//A, G//G e A//G pode ser visualizado na figura 12 . 


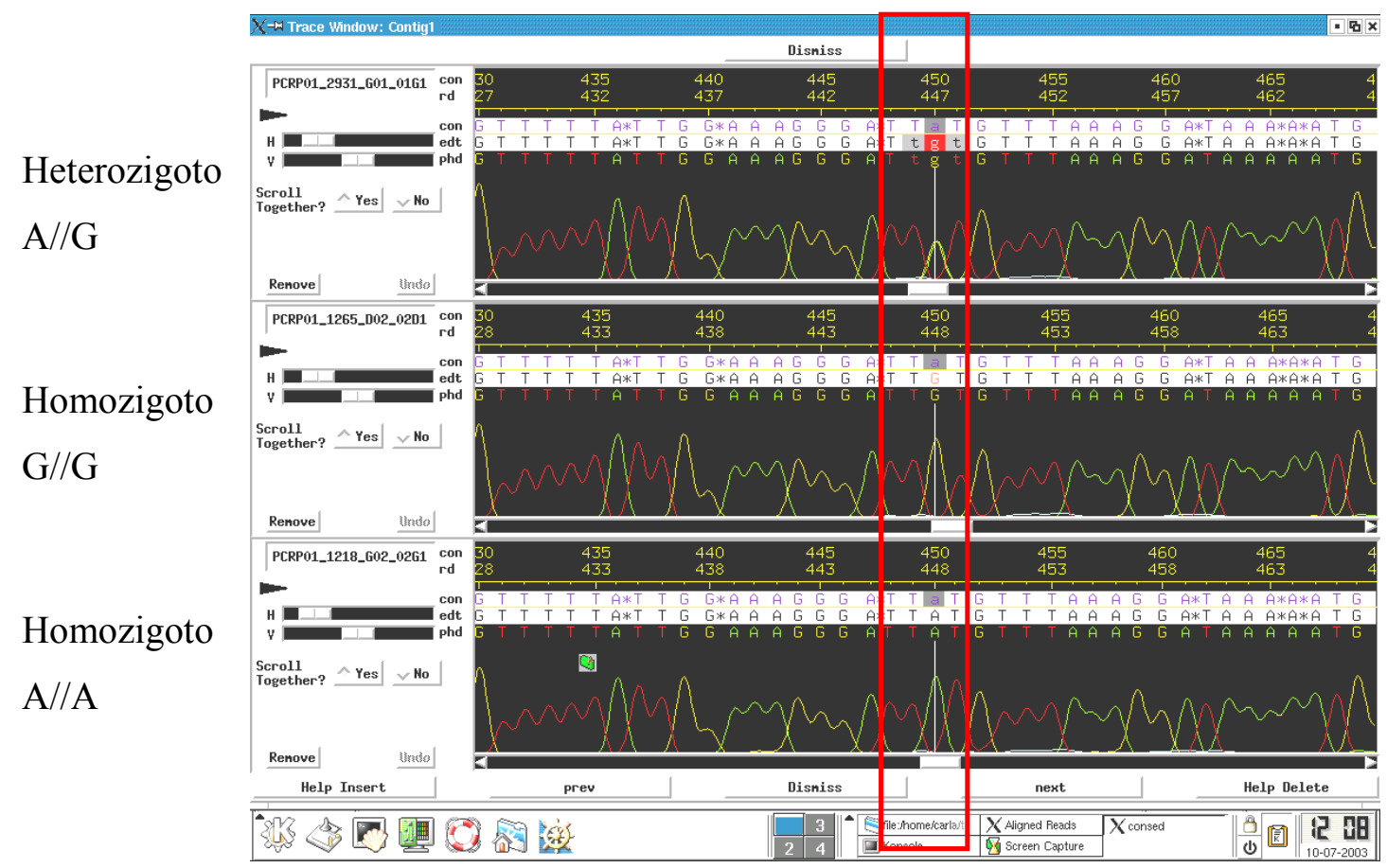

Figura 12 - Padrão dos cromatogramas dos possíveis genótipos no loco A4938G da miostatina, obtidos no seqüenciamento dos produtos de PCR

\subsubsection{Miogenina}

Para a etapa de validação foram selecionados os polimorfismos detectados nos contigs 1 e 2 , referente à extremidade 5 ' seqüenciada, tendo em vista a disponibilidade de primers no Laboratório de Biotecnologia Animal - ESALQ/USP. Para genotipagem foram selecionados os primes PD300 (direto): 5'- AGGCTGAAGAAGGTGAACGA 3', o mesmo utilizado no seqüenciamento dos clones, e foi desenhado um outro primer reverso, R10: 5'- GTGACTCCATGATTCCAGGA - 3', os quais amplificam uma região de $525 \mathrm{pb}$.

As amostras dos 14 parentais do cruzamento TC foram seqüenciadas para confirmação dos polimorfismos detectados nos clones. Após a análise realizada pelos programas Phed/Cap3/Consed, houve a confirmação de quatro polimorfismos anteriormente detectados (figura 13). 
AGGCTGAAGAAGGTGAACGAAGCCTTCGAGGCTCTGAAACGCAGCACTCTGCTCAACCCCAACCAGCG GCTGCCCAAGGTGGAGATCCTGCGCAGCGCCATCCAGTACATCGAGCGCCTGCAGAGCCTGCTCAGCA GCCTCAACCAGCAGGAGCGC ${ }^{1}$ GAGCAGAGGGAGCTGCGCTACCGCCCCGCTGCACCACAACCTGCTGT GAGTGTGGGGATGGGTGGGGATGGGGGGCAGGAGCCGGGGTGGGTGGTGATGGAGGGACGGGGTGGT GATGCTCAGGTTGT² TGTCCCTGTGGGCGGGTGTTGGTGGGTGATGGGCTGATGGCCGTTGCATTGAGC AGAGTGGGTTGGTGGTGCTTGGTGGGGAGTGGGAAGGCTTAAGTCGTAGAAATGATCGTAGAACCATG GGATCAC ${ }^{3}$ AGAGC $^{4}$ CATGGAATCATGG[AATCACA $]^{5} \mathrm{G}[\mathbf{A}]^{5}$ GTCATAGAACCATGGGATCATAGAGTCATG GAATCATGG[AATCACA $]^{6}$ G[A] $]^{6}$ GACATGGAACCATGGGATCATAGAGTCGTGGAATCATGGAATCAC

Figura 13 - Polimorfismos detectados na genotipagem por seqüenciamento da miogenina, na geração parental: $1-\mathrm{C}=>\mathrm{T}$, polimorfismo miog_10 ou nucleotídeo 455 (acesso D90157, NCBI); 2 - T $\Rightarrow$ C, polimorfismo $\operatorname{miog} \_13 ; 3-\mathrm{C}=>\mathrm{T}$, miog_16; $4-\mathrm{C}=>\mathrm{T}, \operatorname{miog} \_16 ; 5$ - Deleção [AATCACA] e [A], polimorfísmo miog_17; 6 - Deleção [AATCACA] e [A], polimorfismo miog_17

$\mathrm{Na}$ etapa de detecção de polimorfismos, o polimorfismo miog_10 $\left(\mathrm{C}^{1}\right)$ situado na região CDS (Coding Sequence - região codificadora), foi encontrado somente em clones $\mathrm{CC}$, caracterizado por uma substituição $\mathrm{C}=>\mathrm{T}$. Porém, segundo a seqüência de cDNA disponível no NCBI sob acesso D90157, o polimorfismo corresponde ao nucleotídeo 455, cujo consenso é uma base T. Sendo assim, na etapa de genotipagem o alelo mutante $\mathrm{C}$ foi encontrado em seis parentais da linhagem TT e somente em duas fêmeas da linhagem CC. Apesar deste polimorfismo estar situado em uma região codificadora, resulta em um polimorfismo sinônimo assim como os demais polimorfismos validados. Este polimorfismo foi denominado T455C.

O polimorfismo miog_13 $\left(\mathrm{T}^{2}\right)$ foi encontrado em um parental $\mathrm{CC}$ e outro da linhagem TT. Os polimorfismo $\mathrm{C}^{3}$ e $\mathrm{C}^{4}$ já foram descritos no banco de dados de SNPs do NCBI sob os números de acesso rs15466453 e rs 15466455, respectivamente. No presente trabalho, foi verificado que os polimorfismos $\mathrm{C}^{3}, \mathrm{C}^{4}$ e os sítios de deleção ocorriam sempre simultaneamente e portanto representavam um único alelo. Este alelo foi encontrado somente nos parentais da linhagem TT. 


\subsubsection{MRF4}

Para a validação dos polimorfismos foram testados ao todo seis primers, dois diretos e quatro reversos, em diversas combinações nas reações de acordo com a temperatura de anelamento característica de cada um. Na tabela 9 estão apresentados os primers com a combinação dos pares testados e tamanho predito dos fragmentos.

Tabela 9. Pares de primers testados na otimização de PCR do gene MRF4 para genotipagem

\begin{tabular}{|c|c|c|}
\hline Identificação & Seqüência & $\begin{array}{l}\text { Tamanho do } \\
\text { produto }\end{array}$ \\
\hline PDMRF4 & 5'-AGGACAAAATGCAGGAGGTG-3' & \\
\hline MRF2S & 5'- GAGAGAGGGGTTAGGGAACG - 3' & $485 \mathrm{pb}$ \\
\hline PDMRF4 & 5'- AGGCTGGATCAGCAGGACAA - 3' & \\
\hline MRF1R & 5'- GAGGAAATGCTGTCCACGAT- 3' & $569 \mathrm{pb}$ \\
\hline PDMRF4 & 5'- AGGCTGGATCAGCAGGACAA - 3' & \\
\hline PRMRF4 & 5' - CTCATTTCTCCACCGCCTCT - 3' & $616 \mathrm{pb}$ \\
\hline PD472/4 & 5'- AGGACAAAATGCAGGAGGTG - 3' & \\
\hline MRF1R & 5'- GAGGAAATGCTGTCCACGAT- 3' & $556 \mathrm{pb}$ \\
\hline PD472/4 & 5'- AGGACAAAATGCAGGAGGTG - 3' & \\
\hline PRMRF4 & 5'- CTCATTTCTCCACCGCCTCT - 3' & $603 \mathrm{pb}$ \\
\hline PD472/4 & 5'- AGGACAAAATGCAGGAGGTG - 3' & \\
\hline MRF2S & 5'- GAGAGAGGGGTTAGGGAACG - 3' & $472 \mathrm{pb}$ \\
\hline PD472/4 & 5'- AGGACAAAATGCAGGAGGTG - 3' & \\
\hline PR872/4 & 5'- GGTGGTCTGTGGGTCAAAAC -3' & $742 \mathrm{pb}$ \\
\hline
\end{tabular}

A seqüência completa do MRF4 de Gallus gallus não está disponível no NCBI, entretanto a seqüência do fragmento de cDNA clonado por Fujisawa-Sehara et al. (1992) está depositada sob o número de acesso D10599. A seqüência similar ao MRF4, 
incluindo 3 regiões codificadores e dois introns está depositada sob o número de acesso GeneID - 417873. A disposição dos primers na seqüência clonada pode ser visualizada na figura 13.
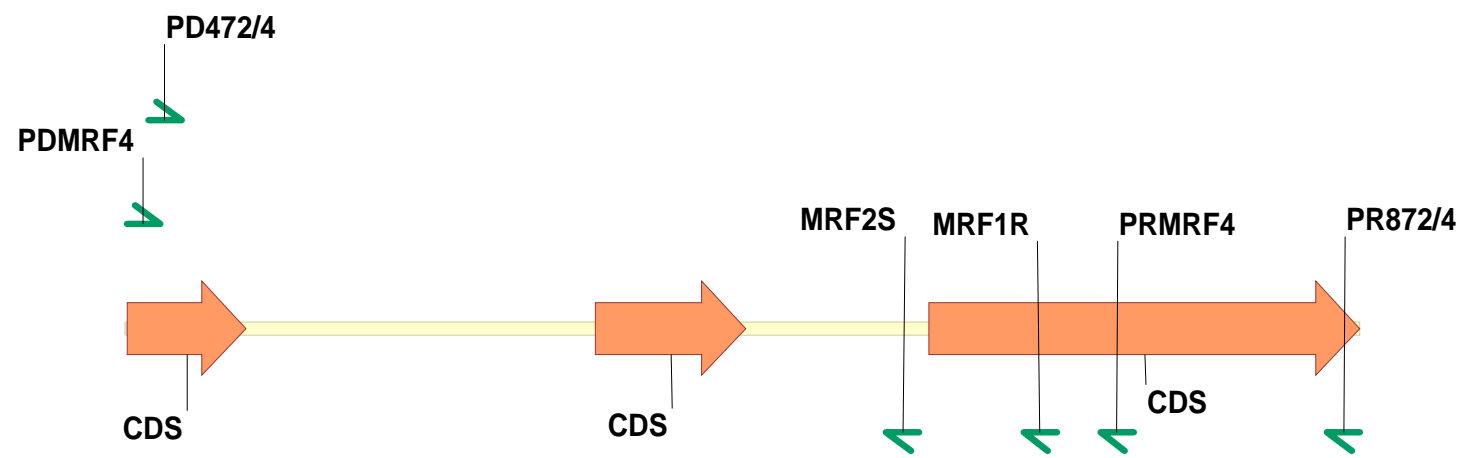

Fragmento clonado

$755 \mathrm{bp}$

Figura 14 - Ilustração do fragmento clonado do gene MRF4 e localização dos primers testados. As regiões CDS foram localizadas pelo alinhamento dos contigs com a seqüência acessada pelo ID - D10599 no NCBI, realizado pelo programa Vector NTI

Finalizadas todas as fases de otimização da PCR para todos os pares de primers do gene MRF4, dois fatores inviabilizaram sua genotipagem. Primeiro, foi que embora as condições ideais para a PCR tenham sido alcançadas, o fragmento de interesse não era amplificado de forma homogênea para todos os indivíduos com os primers testados. Segundo, depois de realizadas novas alterações destas condições, para solucionar o problema anterior, não foi possível eliminar o produto amplificado inespecífico das amostras testadas.

$\mathrm{O}$ alto número de polimorfismos detectados nos clones TT e $\mathrm{CC}$ deve ser considerado como justificativa para o fato de nenhum primer ter amplificado adequadamente. Embora novos primers pudessem ser desenhados, optou-se por não 
fazê-lo, uma vez que a seqüência completa do gene não está disponível no NCBI, e, portanto ficaríamos limitados à seqüência obtida com contigs, reduzindo ainda mais o número de primers que poderiam ser desenhados para amplificar um fragmento de $400 \mathrm{a}$ 600 pares de base.

\subsubsection{Myf5}

Ao todo foram testados oito primers, quatro diretos e quatro reversos, os quais foram utilizados em diversas combinações nas reações segundo a temperatura de anelamento característica de cada um. Na tabela 10 estão apresentados os primer,a combinação de pares testados e tamanho predito dos fragmentos. A localização dos primers no gene Myf5 pode ser visualizada na figura 15. 
Tabela 10 - Pares de primers testados na otimização de PCR do gene Myf5 para genotipagem

\begin{tabular}{|c|c|c|}
\hline Identificação & Seqüência & $\begin{array}{c}\text { Tamanho do } \\
\text { produto }\end{array}$ \\
\hline PDMyf5 & 5'- TCCAGCTGCTCCGATGTGAT- 3' & $704 \mathrm{pb}$ \\
\hline PRMyf5H & 5'- TCATAGCGCCTGGTAGGTCC - 3' & \\
\hline PDMyf5 & 5'- TCCAGCTGCTCCGATGTGAT- 3 & $570 \mathrm{pb}$ \\
\hline PRMyf5 & 5' - ACGATGCTGGAGAGGCAGTC - 3' & \\
\hline PDSMyf5 & 5' - ATGTTGGACGGTTTGGGTTC - 3' & $579 \mathrm{pb}$ \\
\hline PRMyf5H & 5' - TCATAGCGCCTGGTAGGTCC - 3' & \\
\hline PR523/5 & 5'- CTCATAGCGCCTGGTAGGTC - 3' & $663 \mathrm{pb}$ \\
\hline PRMyf5 & 5' - ACGATGCTGGAGAGGCAGTC -3' & \\
\hline PD623/5 & 5'- CTGCTCCGATGTGATGGTAA - 3' & $563 \mathrm{pb}$ \\
\hline PRMyf5 & 5' - ACGATGCTGGAGAGGCAGTC -3' & \\
\hline PDSMyf5 & 5'- ATGTTGGACGGTTTGGGTTC - 3' & $580 \mathrm{pb}$ \\
\hline PR1322/5 & 5'- GGTACATCGAAAGCCTCCAG- 3' & \\
\hline $\mathrm{PD} 523 / 5$ & 5'- CTCATAGCGCCTGGTAGGTC - 3' & $800 \mathrm{pb}$ \\
\hline PR1322/5 & 5'- GGTACATCGAAAGCCTCCAG - 3' & \\
\hline
\end{tabular}




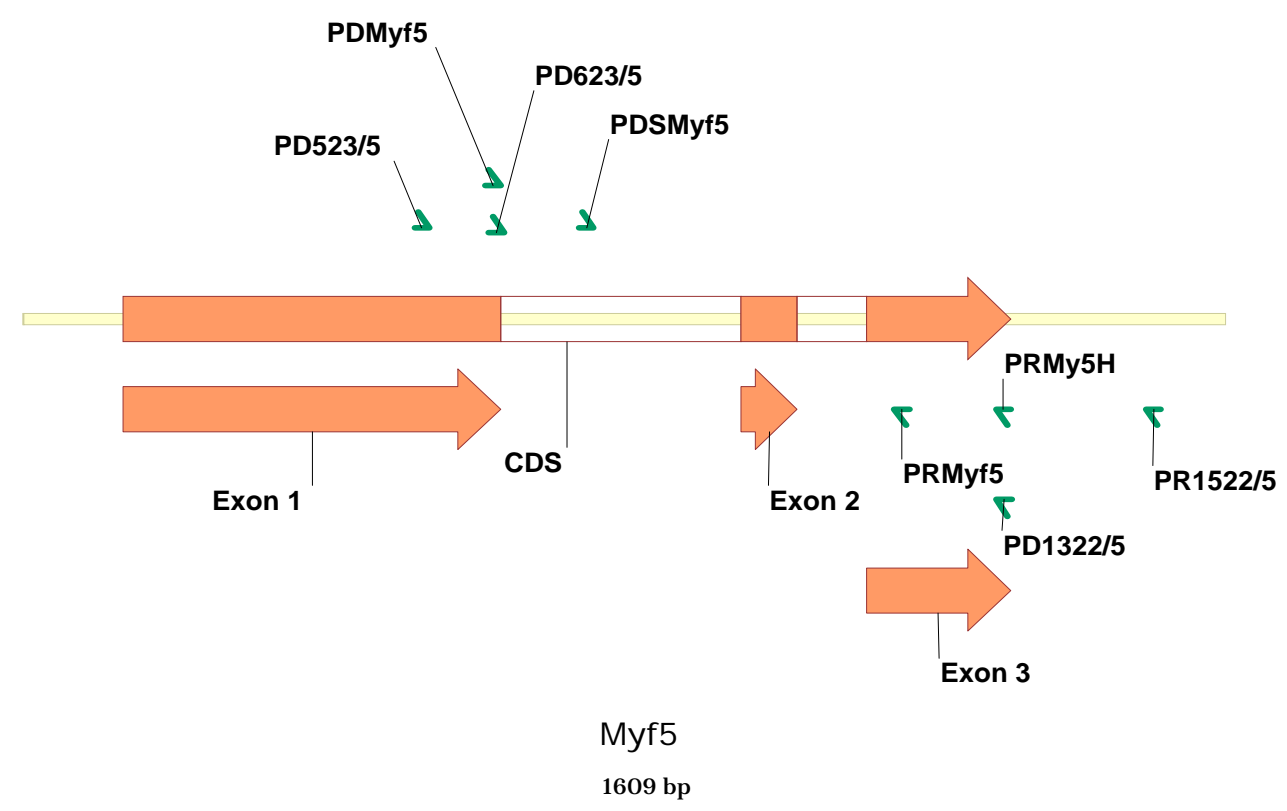

Figura 15 - Gene Myf5 (GenBank, ID: X73250), contendo a localização dos primers testados

Embora a reação de PCR da maior parte dos pares testados tenham resultado em um produto amplificado único, estes por sua vez ao serem seqüenciados e submetidos ao Blastn, não correspondiam à seqüência do gene Myf5 de Gallus gallus.

Sabendo-se que os insertos dos clones foram isolados por eluição em gel de agarose e purificação dos produtos de PCR específicos e inespecíficos, formados pelo par de primers PD523/5 e PR1322/5, o mesmo resultado poderia ser obtido para a genotipagem com esta técnica. Porém, o custo da eluição dos produtos de PCR do gel de agarose para todas as amostras analisadas até o momento, seria inviável. Portanto, optou-se por dar prosseguimento às demais análises somente com os genes da miostatina, miogenina e MyoD.

\subsubsection{MyoD}

A deleção de 13 pares de base foi validada em indivíduos da genotipagem seletiva, onde foi possível verificar sua segregação. Este polimorfismo foi denominado 
D6619-6631, nome que corresponde a uma deleção de nucleotídeos da posição 6619 a 6631 do gene MyoD. O fragmento amplificado é apresentado na figura 1.

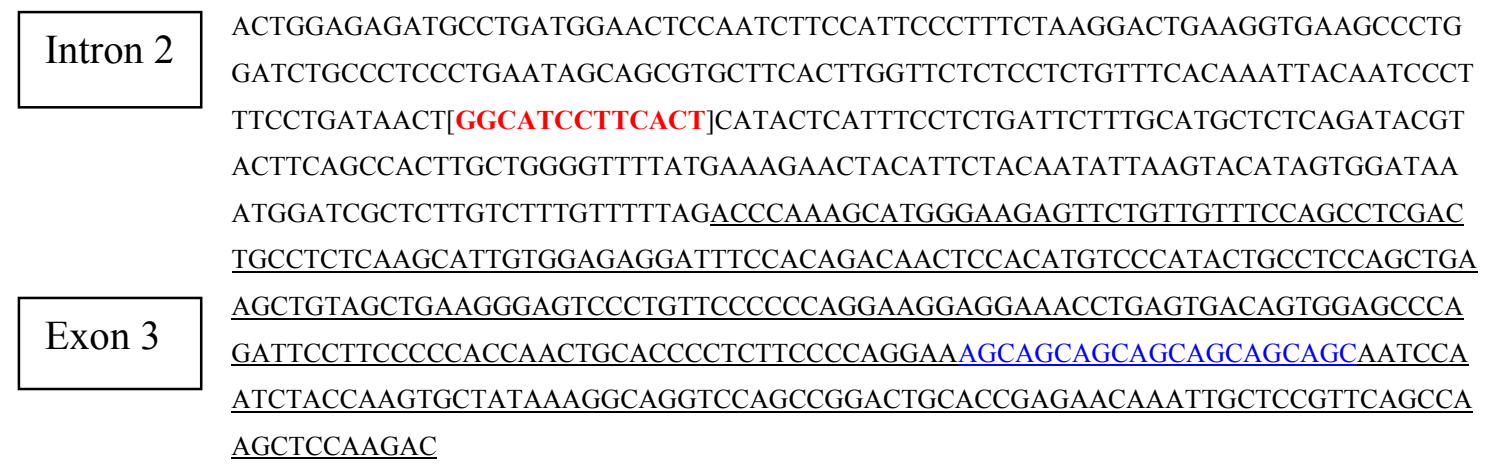

Figura 16 - Produto de PCR seqüenciado do gene MyoD. A deleção de 13 pares de base está destacada em vermelho e a região microssatélite [AGC] em azul

A detecção de polimorfismos pelo seqüenciamento de produtos de PCR do gene MyoD se revelou bastante eficiente. Dentre as vantagens da sua aplicação estão: a praticidade, a rapidez, o baixo custo e maior número de polimorfismos válidos, em relação à clonagem. Entretanto, o principal obstáculo encontrado para a sua utilização foi a investigação de deleções e/ou inserções, uma vez que estas só podem ser nitidamente visualizadas em indivíduos homozigotos. No caso do gene da miogenina, seria impossível identificar o número de deleções presentes nos fragmentos amplificados se estes não tivessem sido clonados.

A investigação de polimorfismos nos genes da miostatina, Myf5, MRF4 e miogenina pelo seqüenciamento de clones se mostrou bastante eficaz, pois gerou um grande número de seqüências de qualidade igual ou superior a 40 , permitindo a identificação de uma grande variedade de alelos, bem como a nítida visualização de deleções. Porém, muitos dos polimorfismos inicialmente detectados em clones não foram confirmados na genotipagem e, portanto não foram validados até o momento. Emara \& Kim (2003) sugerem, dentre outras razões, que isto se deve a erros de incorporação de bases durante o processo de amplificação, clonagem e seqüenciamento, 
e à ausência de polimorfismos nas amostras testadas usadas para validação. Embora muitos dos polimorfismos detectados nos clones não tenham sido validados, estes por sua vez não podem ser classificados como erros de incorporação de nucleotídeos, uma vez que podem pertencer aos parentais do cruzamento $\mathrm{CT}$, os quais não foram genotipados neste trabalho. Por outro lado, particularmente no caso do gene MRF4, a ocorrência de erros de incorporação de bases deve ser levada em consideração. Este gene apresentou uma média de 12,5 SNPs por 100 pares de base, média muito superior às estimativas descritas na literatura para aves, as quais variam de 1,69 a 3,69 SNPs por 100 pares (Weigend \& Romanov, 2001). Rothschild \& Soller (1999) por sua vez, descrevem que a ocorrência de um polimorfismo a cada 700-1000pb estaria dentro de uma média aceitável. Desta forma, um típico gene candidato, considerando regiões de introns, exons e regiões regulatórias 5' e 3', pode incluir entre 5 e 20 sítios polimórficos em toda sua extensão, enquanto que o fragmento seqüenciado do MRF4 de 742 pb, apresentou 128 sítios polimórficos.

Neste contexto, a utilização de enzimas de alta fidelidade nas reações de PCR é fundamental na etapa de detecção de polimorfismos em fragmentos clonados. Outra forma bem sucedida de deteç̧ão e validação de polimorfismos na população é pelo seqüenciamento de produtos de PCR em duas ou mais gerações de uma mesma população, como foi realizado com o gene MyoD. Esta metodologia permite o acompanhamento da segregação de polimorfismos através das gerações, possibilitando a identificação de possíveis artefatos.

Os inúmeros polimorfismos detectados neste trabalho poderiam contribuir para a melhoria da resolução no mapeamento de QTL da população estudada com o fornecimento de marcadores SNPs para a identificação de QTNs, assim como para novas abordagens voltadas para a análise de genes candidatos.

\subsection{Análise Estatística}

Os polimorfismos validados foram utilizados como marcadores nas três fases de genotipagem: genotipagem da geração parental do cruzamento TC, para validação dos 
polimorfismos detectados; genotipagem seletiva da geração F2, para identificação dos polimorfismos de maior relevância; e genotipagem dos indivíduos F2 pertencentes às famílias informativas, para avaliação dos efeitos de genótipo. Tendo em vista que a finalização da etapa de validação somente foi possível para os genes da miostatina, miogenina e MyoD, os genes Myf5 e MRF4 não puderam ser genotipados e conseqüentemente não foram incluídos nas análises estatísticas. Os polimorfismos utilizados na genotipagem são apresentados na tabela 11 .

Tabela 11. Genes e respectivos loco selecionados para a etapa de genotipagem

\begin{tabular}{lcll}
\hline Gene & Polimorfismo & Localização & $\begin{array}{l}\text { Identificação } \\
\text { do loco }\end{array}$ \\
\hline miostatina & $\mathrm{A}=>\mathrm{G}$ & nucleotídeo 4.938 (acesso AF346599) & A4938G \\
& $\mathrm{T}=>\mathrm{C}$ & nucleotídeo 455 (acesso D90157) & T455C \\
miogenina & $\mathrm{T}=>\mathrm{C}$ & $\begin{array}{l}\text { nucleotídeo 283, contig 2 miogenina } \\
\text { nucleotídeo 431, contig 2 miogenina }\end{array}$ & $\begin{array}{l}\text { miog_13 } \\
\text { miog_16 }\end{array}$ \\
& $\mathrm{C}=>\mathrm{T}^{\mathrm{a}}$ & nucleotídeos 6619-6631 (L34006) & \\
MyoD & deleção 13 pares & & D6619-6631 \\
\hline
\end{tabular}

\subsubsection{Seleção dos animais para genotipagem seletiva}

A característica escolhida para a seleção dos animais de desempenho extremo foi a de peso vivo aos 42 dias de idade (PV42). As correlações fenotípicas entre este caráter e as principais características de desempenho e carcaça para os 2063 animais F2 do cruzamento TC, são apresentadas na tabela 12 e 13. 
Tabela 12. Correlações fenotípicas entre PV42 e características de desempenho de 2063 aves da geração F2 do cruzamento TC

\begin{tabular}{lcccccc}
\hline Caráter & PV42 & PV35 & PV41 & GP & CA & CI \\
\hline PV42 & 1 & 0,86 & 0,99 & 0,66 & $-0,09$ & 0,44 \\
PV35 & 1 & 0,86 & 0,38 & 0,01 & 0,47 \\
PV41 & & 1 & 0,86 & $-0,11$ & 0,43 \\
GP & \multicolumn{7}{r}{} & 1 & $-0,32$ & 0,23 \\
CA & & & 1 & $-0,04$ \\
CI & & & 1 \\
PV35, PV41, PV42 - peso vivo aos 35, 41 e 42 dias, respectivamente; GP - ganho de peso dos 35 aos 42 dias; CA - \\
conversão alimentar; CI - comprimento do intestino.
\end{tabular}

Tabela 13. Correlações fenotípicas entre PV42 e caractrerísticas de carcaça de 2063 aves da geração F2 do cruzamento TC

\begin{tabular}{lccccccc}
\hline Caráter & PV42 & PEIT & PC & CARC & GA & FI & COR \\
\hline PV42 & 1 & 0,79 & 0,87 & 0,84 & 0,61 & 0,68 & 0,48 \\
PEIT & & 1 & 0,83 & 0,95 & 0,53 & 0,59 & 0,59 \\
PC & & 1 & 0,9 & 0,62 & 0,67 & 0,67 \\
CARC & & & & 1 & 0,61 & 0,64 & 0,64 \\
GA & & & & 1 & 0,48 & 0,48 \\
FI & & & & 1 & 0,42 \\
COR & & & & & 1 \\
PV42 - peso vivo aos 42 dias de idade; PC - peso da coxa; PEIT - peso do peito; CARC - peso da carcaça; & PCARC - \\
porcentagem de carcaca; GA - peso da gordura abdominal; FI - peso do figado; COR - peso do coração;
\end{tabular}

Após a revisão preliminar dos dados fenotípicos o número amostral de animais foi reduzido para um total de 1860 aves, as quais foram divididas em 925 fêmeas e 934 machos. Foram genotipados um total de 170 animais, representando $9 \%$ do total de indivíduos F2 do cruzamento TC.

As médias e desvios-padrão da característica de PV42 ajustada nos grupos de animais leves e pesados foram $801,5 \pm 93,8 \mathrm{~g}$ e 1328,5 $\pm 127,8 \mathrm{~g}$, respectivamente. 


\subsubsection{Test $\chi 2$ da genotipagem seletiva}

Os resultados do teste qui-quadrado para a hipótese de homogeneidade alélica entre o grupo de animais leves e pesados, para os genes da miostatina, miogenina e MyoD estão descritos na tabela 14.

Tabela 14. Freqüências alélicas e probabilidades do teste qui-quadrado para cada loco genotipado

\begin{tabular}{llcllc}
\hline Gene & Loco & Alelos & leves & pesados & Probabilidade do $\chi^{2}$ \\
Miostatina & A4938G & A & 0,364706 & 0,332353 & \\
& & G & 0,129412 & 0,173529 & 0,0890269 \\
Miogenina & T455C & T & 0,331361 & 0,340237 & \\
& & C & 0,16568 & 0,162722 & 0,84782473 \\
& miog_13 & T & 0,435294 & 0,447059 & \\
& & C & 0,064706 & 0,052941 & 0,50075624 \\
& miog_16 & T & 0,111765 & 0,117647 & \\
& & C & 0,388235 & 0,382353 & 0,796429 \\
MyoD & D6619-6631 & C & 0,424837 & 0,405229 & \\
& & D & 0,091503 & 0,078431 & 0,72606193 \\
\hline
\end{tabular}

Segundo o resultado do teste qui-quadrado, foi verificado que o polimorfismo do gene da miostatina apresentou maior relevância em relação à característica de peso vivo aos 42 dias $(\mathrm{P}=0,089)$. $\mathrm{O}$ estabelecimento da estratégia de genotipagem da geração $\mathrm{F} 2$ foi feito com base nesta análise, uma vez que possibilitou a seleção das famílias informativas para o loco de maior interesse, o loco A4938G.

\subsubsection{Genotipagem dos indivíduos F2 das famílias informativas}

Foram selecionadas todas as famílias informativas para o loco da miostatina, incluindo ao todo três famílias: 7713, 7972 e 7709 Foram selecionados ao acaso 32 
indivíduos de cada família com números iguais de machos e fêmeas. A estatística descritiva dos caracteres estudados nos 96 indivíduos genotipados está apresentada na tabela 15. Na tabela 16 está a descrição dos dados fenotípicos discriminados por família.

Tabela 15. Média, desvio padrão (DP) e coeficiente de variação (CV) dos 96 animais das famílias informativas

\begin{tabular}{|c|c|c|c|}
\hline Caráter & Média & DP & $\mathrm{CV}$ \\
\hline PN (g) & 44,04 & 4,44 & 10,08 \\
\hline PV35 (g) & 818,72 & 107,93 & 13,18 \\
\hline PV41 (g) & 1045,56 & 138,98 & 13,29 \\
\hline PV42 (g) & 1012,32 & 139,79 & 13,81 \\
\hline GP $(\mathrm{g})$ & 226,84 & 48,65 & 21,45 \\
\hline GP35 (g) & 774,68 & 107,82 & 13,92 \\
\hline GP41 (g) & 1001,53 & 138,51 & 13,83 \\
\hline GP42 (g) & 968,29 & 139,16 & 14,37 \\
\hline CA (kg ração/kg pv) & 2,66 & 0,43 & 16,17 \\
\hline $\mathrm{EF}$ & 0,39 & 0,06 & 15,38 \\
\hline PA (g) & 84,08 & 11,42 & 13,58 \\
\hline $\mathrm{PC}(\mathrm{g})$ & 214,03 & 36,97 & 17,27 \\
\hline PEIT (g) & 159,18 & 26,11 & 16,40 \\
\hline PPEIT (\%) & 15,70 & 1,02 & 6,50 \\
\hline CARR (g) & 192,69 & 30,99 & 16,08 \\
\hline CARC (g) & 649,98 & 100,22 & 15,42 \\
\hline PCARC $(\%)$ & 64,09 & 1,95 & 3,04 \\
\hline GA $(g)$ & 18,91 & 6,98 & 36,91 \\
\hline PGA (\%) & 1,84 & 0,58 & 31,52 \\
\hline FI $(g)$ & 27,11 & 4,16 & 15,34 \\
\hline $\operatorname{COR}(\mathrm{g})$ & 6,19 & 1,28 & 20,68 \\
\hline PU (g) & 8,15 & 1,99 & 24,42 \\
\hline MO (g) & 28,03 & 3,77 & 13,45 \\
\hline $\mathrm{CI}(\mathrm{cm})$ & 160,3 & 12,96 & 8,08 \\
\hline
\end{tabular}


Tabela 16. Média, desvio padrão (DP) e coeficiente de variação (CV) dos 96 animais por família

\begin{tabular}{|c|c|c|c|c|c|c|c|c|c|}
\hline \multirow{2}{*}{$\begin{array}{l}\text { Família } \\
\text { Caráter }\end{array}$} & \multicolumn{3}{|c|}{7709} & \multicolumn{3}{|c|}{7713} & \multicolumn{3}{|c|}{7972} \\
\hline & Média & Desvio & $\mathrm{CV}$ & Média & Desvio & $\mathrm{CV}$ & Média & Desvio & $\mathrm{CV}$ \\
\hline PN (g) & 41,3 & 2,3 & 5,6 & 41,7 & 2,6 & 6,2 & 49,2 & 2,8 & 5,7 \\
\hline PV35 (g) & 852,4 & 83,1 & 9,7 & 784,4 & 120,9 & 15,4 & 819,4 & 108,6 & 13,3 \\
\hline PV41 (g) & 1073,3 & 108,7 & 10,1 & 997,8 & 156,8 & 15,7 & 1065,7 & 138,7 & 13,0 \\
\hline PV42 (g) & 1042,8 & 106,8 & 10,2 & 955,4 & 151,9 & 15,9 & 1038,8 & 142,7 & 13,7 \\
\hline GP $(g)$ & 220,9 & 45,1 & 20,4 & 213,3 & 44,5 & 20,9 & 246,3 & 51,2 & 20,8 \\
\hline GP35 (g) & 811,1 & 82,4 & 10,2 & 742,7 & 120,2 & 16,2 & 770,2 & 109,2 & 14,2 \\
\hline GP41 (g) & 1032,0 & 108,0 & 10,5 & 956,1 & 156,3 & 16,3 & 1016,5 & 139,3 & 13,7 \\
\hline GP42 (g) & 1001,6 & 106,0 & 10,6 & 913,7 & 151,2 & 16,6 & 989,6 & 143,3 & 14,5 \\
\hline CA (kg ração/kg pv) & 2,7 & 0,4 & 15,7 & 2,8 & 0,5 & 16,9 & 2,5 & 0,4 & 15,0 \\
\hline $\mathrm{EF}$ & 0,4 & 0,1 & 15,8 & 0,4 & 0,1 & 13,5 & 0,4 & 0,1 & 15,0 \\
\hline PA (g) & 87,6 & 8,8 & 10,0 & 79,4 & 12,1 & 15,3 & 85,3 & 11,8 & 13,8 \\
\hline $\mathrm{PC}(\mathrm{g})$ & 217,6 & 34,0 & 15,6 & 200,7 & 36,9 & 18,4 & 223,8 & 37,1 & 16,6 \\
\hline PEIT (g) & 167,2 & 21,8 & 13,0 & 153,9 & 28,5 & 18,5 & 156,4 & 26,5 & 16,9 \\
\hline PPEIT (\%) & 16,0 & 1,0 & 6,2 & 16,1 & 0,8 & 4,9 & 15,0 & 0,9 & 6,1 \\
\hline CARR (g) & 198,3 & 23,5 & 11,9 & 182,4 & 33,7 & 18,5 & 197,4 & 33,0 & 16,7 \\
\hline CARC (g) & 670,7 & 78,9 & 11,8 & 616,4 & 108,5 & 17,6 & 662,8 & 104,8 & 15,8 \\
\hline PCARC (\%) & 64,3 & 2,5 & 3,9 & 64,4 & 1,5 & 2,3 & 63,6 & 1,7 & 2,7 \\
\hline GA $(g)$ & 20,3 & 6,7 & 32,9 & 14,3 & 5,1 & 35,8 & 22,1 & 6,6 & 29,8 \\
\hline PGA (\%) & 1,9 & 0,5 & 27,5 & 1,5 & 0,4 & 28,6 & 2,1 & 0,6 & 27,2 \\
\hline $\mathrm{FI}(\mathrm{g})$ & 28,0 & 4,5 & 16,2 & 25,8 & 3,9 & 15,0 & 27,5 & 3,8 & 13,9 \\
\hline $\operatorname{COR}(\mathrm{g})$ & 5,8 & 1,1 & 18,0 & 6,3 & 1,4 & 21,8 & 6,4 & 1,3 & 21,0 \\
\hline PU (g) & 7,8 & 2,0 & 25,4 & 7,9 & 1,8 & 22,5 & 8,7 & 2,2 & 24,8 \\
\hline $\mathrm{MO}(\mathrm{g})$ & 28,6 & 3,7 & 12,8 & 26,9 & 3,5 & 13,0 & 28,6 & 4,0 & 14,0 \\
\hline $\mathrm{CI}(\mathrm{cm})$ & 162,8 & 14,0 & 8,6 & 155,9 & 12,1 & 7,8 & 162,3 & 11,9 & 7,4 \\
\hline
\end{tabular}




\subsubsection{Análise de variância}

\section{Modelo de único gene (Single-Gene Model)}

Nesta análise foram estudados os locos A4938G da miostatina, D6619-6631 do gene MyoD e os três locos da miogenina T455C, miog_13 e miog_16. Foi possível identificar a presença de todos os possíveis genótipos dentro da amostra para os locos da miostatina e MyoD. No gene da miogenina foi constatada a presença de somente dois genótipos em cada um dos três locos dentro da amostra. A freqüência dos genótipos para cada loco é apresentada na tabela 17.

Tabela 17. Freqüência de genótipos na amostra para um total de 86 observações válidas para os genes da miostatina, miogenina e MyoD

\begin{tabular}{llcc}
\hline Gene & Loco & Genótipos & Freqüência \\
\hline Miostatina & A4938G & $1(\mathrm{AA})$ & 27 \\
& & $2(\mathrm{AG})$ & 45 \\
Miogenina & $3(\mathrm{GG})$ & 14 \\
& T455C & $1(\mathrm{TT})$ & 36 \\
& $2(\mathrm{TC})$ & 50 \\
& & $1(\mathrm{TT})$ & 67 \\
& miog_13 & $2(\mathrm{TC})$ & 19 \\
& & 56 \\
MyoD & $1(\mathrm{CC})$ & 30 \\
& & $2(\mathrm{CT})$ & 28 \\
& & $1(\mathrm{CC})$ & 50 \\
\hline
\end{tabular}

Visto que o gene da miogenina teve três locos genotipados, foram realizadas análises de variância seguindo o modelo de único gene para cada um isoladamente, assim como para os genes da miostatina e MyoD. 
Segundo Rothschild \& Soller (1999), se uma seqüência possui $n$ locos dialélicos, o número total de diferentes haplótipos intragênicos nesta seqüência é $2^{n}$. Sendo assim, a análise dos três alelos da miogenina como um único loco permitiu a identificação de cinco haplótipos intragênicos ou "alelos de seqüência" (Anexo F). Entretanto, na análise multigênica foram utilizados unicamente os dados da genotipagem do loco T455C, uma vez que este apresentou maior relevância na análise do modelo de único gene.

As probabilidades $\mathrm{F}$ da soma de quadrados tipo III do SAS pelo grupo de modelos de único gene (Single-gene Model), para o gene da miostatina, MyoD e o loco T455C da miogenina, estão descritas na tabela 18, 19 e 20, respectivamente. As probabilidades $\mathrm{F}$ dos demais locos do gene da miogenina estão descritas no Anexo F. 
Tabela 18. Valores de probabilidade do teste F, coeficiente de variação (CV), coeficiente de determinação $\left(\mathrm{R}^{2}\right)$ de acordo com o modelo de um único gene para o loco A4938G do gene da miostatina

\begin{tabular}{lccc}
\hline Caráter & CV & Probabilidade & $\mathrm{R}^{2}$ \\
\hline PN & 4,14 & 0,6551 & 0,8840 \\
PV35 & 9,93 & 0,8116 & 0,5303 \\
PV41 & 9,26 & 0,8315 & 0,6083 \\
PV42 & 9,41 & 0,9459 & 0,6168 \\
GP & 15,38 & 0,7173 & 0,5914 \\
GP35 & 10,49 & 0,8036 & 0,5312 \\
GP41 & 9,66 & 0,8224 & 0,6067 \\
GP42 & 9,84 & 0,6145 & 0,9405 \\
CA & 12,92 & 0,8509 & 0,3643 \\
EF & 12,47 & 0,8932 & 0,3733 \\
PA & 9,16 & 0,9098 & 0,6161 \\
PC & 12,16 & 0,9071 & 0,5820 \\
PEIT & 11,90 & 0,9990 & 0,5628 \\
PPEIT & 5,02 & 0,2824 & 0,6122 \\
CARR & 12,40 & 0,9786 & 0,5263 \\
CARC & 10,84 & 0,9155 & 0,5949 \\
PCARC & 2,86 & 0,5812 & 0,3071 \\
GA & 29,34 & 0,4456 & 0,4646 \\
PGA & 24,28 & 0,2968 & 0,4955 \\
FI & 13,79 & 0,9624 & 0,3163 \\
COR & 17,38 & 0,6618 & 0,4964 \\
PU & 22,51 & 0,3902 & 0,2945 \\
MO & 11,42 & 0,6492 & 0,4228 \\
CI & 7,06 & 0,8933 & 0,3408 \\
\hline PN & 1,0642 &
\end{tabular}

PN - peso ao nascimento; PV35, PV41, PV42 - peso vivo aos 35, 41 e 42 dias, respectivamente; GP - ganho de peso dos 35 aos 42 dias; GP35, GP41 e GP42 - ganho de peso do nascimento aos 35, 41 e 42 dias, respectivamente; CA - conversão alimentar; EF eficiência alimentar; PA - peso da asa; PC - peso da coxa; PEIT - peso do peito; PPEIT - porcentagem de peito; CARR - peso da carcaça residual; CARC - peso da carcaça; PCARC - porcentagem de carcaça; GA - peso da gordura abdominal; PGA porcentagem de gordura; FI - peso do figado; COR - peso do coração; PU - peso do pulmão; MO - peso da moela; CI comprimento do intestino. 
Tabela 19. Valores de probabilidade do teste $F$, coeficiente de variação (CV), coeficiente de determinação $\left(\mathrm{R}^{2}\right)$ de acordo com o modelo de um único gene para o loco D6619-6631 do gene MyoD

\begin{tabular}{lccc}
\hline Caráter & CV & Probabilidade & $\mathrm{R}^{2}$ \\
\hline PN & 4,10 & 0,3711 & 0,8863 \\
PV35 & 9,90 & 0,6549 & 0,5332 \\
PV41 & 9,26 & 0,8455 & 0,6081 \\
PV42 & 9,39 & 0,8245 & 0,6183 \\
GP & 15,13 & 0,2220 & 0,6047 \\
GP35 & 10,46 & 0,6923 & 0,5333 \\
GP41 & 9,67 & 0,8681 & 0,6061 \\
GP42 & 9,82 & 0,8506 & 0,6157 \\
CA & 0,9425 & 0,3624 \\
EF & 12,94 & 0,8421 & 0,3743 \\
PA & 12,46 & 0,9158 & 0,6160 \\
PC & 9,16 & 0,7964 & 0,5835 \\
PEIT & 12,14 & 0,7695 & 0,5661 \\
PPEIT & 11,85 & 0,5041 & 0,6043 \\
CARR & 5,07 & 0,7775 & 0,5295 \\
CARC & 12,36 & 0,7444 & 0,5973 \\
PCARC & 10,80 & 0,4960 & 0,3102 \\
GA & 2,85 & 0,6367 & 0,4591 \\
PGA & 29,49 & 0,5384 & 0,4870 \\
FI & 24,49 & 0,3568 & 0,3352 \\
COR & 13,60 & 0,9053 & 0,4915 \\
PU & 17,47 & 0,4619 & 0,2911 \\
MO & 22,56 & 0,4908 & 0,4273 \\
CI & 11,37 & 0,1749 & 0,3704 \\
\hline
\end{tabular}

PN - peso ao nascimento; PV35, PV41, PV42 - peso vivo aos 35, 41 e 42 dias, respectivamente; GP - ganho de peso dos 35 aos 42 dias; GP35, GP41 e GP42 - ganho de peso do nascimento aos 35, 41 e 42 dias, respectivamente; CA - conversão alimentar; EF eficiência alimentar; PA - peso da asa; PC - peso da coxa; PEIT - peso do peito; PPEIT - porcentagem de peito; CARR - peso da carcaça residual; CARC - peso da carcaça; PCARC - porcentagem de carcaça; GA - peso da gordura abdominal; PGA porcentagem de gordura; FI - peso do figado; COR - peso do coração; PU - peso do pulmão; MO - peso da moela; CI comprimento do intestino. 
Tabela 20. Valores de probabilidade do teste F, coeficiente de variação (CV), coeficiente de determinação $\left(\mathrm{R}^{2}\right)$ de acordo com o modelo de um único gene para o loco T455C do gene da miogenina

\begin{tabular}{|c|c|c|c|c|c|}
\hline \multirow[t]{2}{*}{ Caráter } & \multirow[t]{2}{*}{$\mathrm{CV}$} & \multicolumn{2}{|c|}{ Média } & \multirow[t]{2}{*}{ Probabilidade } & \multirow[t]{2}{*}{$\mathrm{R}^{2}$} \\
\hline & & genótipo $\mathrm{T} / \mathrm{T}$ & genótipo $\mathrm{T} / \mathrm{C}$ & & \\
\hline $\mathrm{PN}$ & 4,07 & 44,14 & 44,48 & 0,1819 & 0,8859 \\
\hline PV35 & 9,73 & 798,60 & 827,47 & 0,1357 & 0,5424 \\
\hline PV41 & 8,97 & $1.018,93$ & $1.063,63$ & $0,0510^{\dagger}$ & 0,6272 \\
\hline PV42 & 9,03 & 978,81 & $1.028,59$ & $0,0263^{*}$ & 0,6425 \\
\hline GP & 14,88 & 219,48 & 236,47 & $0,0368^{*}$ & 0,6120 \\
\hline GP35 & 10,29 & 754,88 & 782,86 & 0,1479 & 0,5423 \\
\hline GP41 & 9,37 & 975,21 & $1.019,02$ & $0,0557^{\dagger}$ & 0,6248 \\
\hline GP42 & 9,44 & 935,08 & 983,99 & $0,0291^{*}$ & 0,6394 \\
\hline $\mathrm{CA}$ & 12,68 & 2,70 & 2,59 & 0,1592 & 0,3788 \\
\hline $\mathrm{EF}$ & 12,13 & 0,38 & 0,40 & $0,0750^{\dagger}$ & 0,3986 \\
\hline PA & 8,70 & 81,02 & 85,61 & $0,0099^{* *}$ & 0,6493 \\
\hline $\mathrm{PC}$ & 11,83 & 206,50 & 217,31 & $0,0752^{\dagger}$ & 0,5990 \\
\hline PEIT & 11,52 & 154,88 & 163,15 & $0,0647^{\dagger}$ & 0,5838 \\
\hline PPEIT & 5,08 & 15,64 & 15,77 & 0,8311 & 0,5950 \\
\hline CARR & 11,66 & 181,29 & 196,65 & $0,0056^{* *}$ & 0,5755 \\
\hline CARC & 10,39 & 625,01 & 662,26 & $0,0245^{*}$ & 0,6224 \\
\hline PCARC & 2,82 & 63,72 & 64,26 & 0,2140 & 0,3115 \\
\hline GA & 28,54 & 16,49 & 19,31 & $0,0320^{*}$ & 0,4863 \\
\hline PGA & 24,05 & 1,67 & 1,85 & $0,0935^{\dagger}$ & 0,4981 \\
\hline FI & 13,30 & 25,72 & 27,52 & $0,0373^{*}$ & 0,3559 \\
\hline COR & 17,25 & 6,07 & 6,31 & 0,3713 & 0,4962 \\
\hline PU & 21,88 & 7,53 & 8,49 & $0,0262^{*}$ & 0,3239 \\
\hline MO & 11,15 & 26,96 & 28,31 & $0,0703^{\dagger}$ & 0,4419 \\
\hline CI & 6,99 & 158,33 & 160,15 & 0,4925 & 0,3431 \\
\hline
\end{tabular}

PN - peso ao nascimento; PV35, PV41, PV42 - peso vivo aos 35, 41 e 42 dias, respectivamente; GP - ganho de peso dos 35 aos 42 dias; GP35, GP41 e GP42 - ganho de peso do nascimento aos 35, 41 e 42 dias, respectivamente; CA - conversão alimentar; EF eficiência alimentar; PA - peso da asa; PC - peso da coxa; PEIT - peso do peito; PPEIT - porcentagem de peito; CARR - peso da carcaça residual; CARC - peso da carcaça; PCARC - porcentagem de carcaça; GA - peso da gordura abdominal; PGA porcentagem de gordura; FI - peso do figado; COR - peso do coração; PU - peso do pulmão; MO - peso da moela; CI comprimento do intestino.

** significativo a $\mathrm{P} \leq 0,01 ;$ * significativo a $\mathrm{P} \leq 0,05$ e ${ }^{\dagger}$ significativo a $\mathrm{P} \leq 0,10$.

Os genótipos dos genes da miostatina e MyoD não apresentaram efeito significativo sobre nenhum dos caracteres estudados. Houve efeito estatisticamente significativo do loco T455C da miogenina nos caracteres PA e CARR a 1\%, e caracteres PV42, GP, GPN42, CARC, GA, FI e PU a 5\%. 
O loco miog_13 não apresentou efeito estatisticamente significativo sobre nenhum dos caracteres, enquanto que o loco miog_16 afetou o caractere $\mathrm{EF}(\mathrm{P}<0,05)$. O loco intragênico gerado pelos três polimorfismos da miogenina afetaram os caracteres CARR ( $<<0,01)$, CARC e PU $(\mathrm{P}<0,05)$.

\section{Modelo multigênico (Multi-gene Model)}

A análise multigênica quando comparada à análise de um único gene tem como objetivo avaliar todas as fontes de variação do fenótipo incluindo os efeitos fixos de genótipo de todos os genes. Em geral, esta análise tende a reduzir a estimativa do efeito do genótipo dos genes isoladamente, uma vez que diminui o número de graus de liberdade do resíduo (Bovenhuis et al, 1992). Os resultados da análise de variância no modelo multigênico são apresentados na tabela 21 . 
Tabela 21. Valores de probabilidade do teste $F$, coeficiente de variação (CV) e coeficiente de determinação $\left(\mathrm{R}^{2}\right)$ de acordo com o modelo multigênico

\begin{tabular}{llllll}
\hline Caráter & CV & Miostatina & Miogenina & MyoD & $\mathrm{R}^{2}$ \\
\hline PN & 4,12 & 0,6257 & 0,2524 & 0,4283 & 0,8911 \\
PV35 & 9,95 & 0,7873 & 0,1773 & 0,8150 & 0,5487 \\
PV41 & 9,18 & 0,8060 & $0,0578^{\dagger}$ & 0,8595 & 0,6312 \\
PV42 & 9,28 & 0,9222 & $0,0359^{*}$ & 0,9745 & 0,6437 \\
GP & 14,75 & 0,6805 & $0,0199^{*}$ & 0,0948 & 0,6403 \\
GP35 & 10,53 & 0,7806 & 0,1889 & 0,8438 & 0,5482 \\
GP41 & 9,60 & 0,7975 & $0,0618^{\dagger}$ & 0,8676 & 0,6288 \\
GP42 & 9,71 & 0,9177 & $0,0387^{*}$ & 0,9846 & 0,6405 \\
CA & 13,01 & 0,9055 & 0,1754 & 0,8943 & 0,3826 \\
EF & 12,43 & 0,9394 & $0,0852^{\dagger}$ & 0,7895 & 0,4036 \\
PA & 8,88 & 0,8556 & $0,0084^{* *}$ & 0,7281 & 0,6543 \\
PC & 12,12 & 0,8584 & $0,0826^{\dagger}$ & 0,8929 & 0,6024 \\
PEIT & 11,85 & 0,9958 & $0,0899^{\dagger}$ & 0,9272 & 0,5848 \\
PPEIT & 5,09 & 0,3092 & 0,9915 & 0,5313 & 0,6213 \\
CARR & 11,96 & 0,9439 & $0,0075^{* *}$ & 0,8730 & 0,5783 \\
CARC & 10,65 & 0,8707 & $0,0324^{*}$ & 0,8988 & 0,6254 \\
PCARC & 2,86 & 0,5922 & 0,2000 & 0,6043 & 0,3347 \\
GA & 28,90 & 0,4957 & $0,0509^{\dagger}$ & 0,6401 & 0,5023 \\
PGA & 24,15 & 0,3140 & 0,1434 & 0,5327 & 0,5222 \\
FI & 13,46 & 0,8312 & $0,0419^{*}$ & 0,3764 & 0,3761 \\
COR & 17,64 & 0,6205 & 0,3510 & 0,8574 & 0,5057 \\
PU & 21,83 & 0,2944 & $0,0164^{*}$ & 0,4430 & 0,3644 \\
MO & 11,33 & 0,8099 & $0,0976^{\dagger}$ & 0,5960 & 0,4552 \\
CI & 7,00 & 0,8839 & 0,4198 & 0,1654 & 0,3787 \\
\hline PN & & 0934 &
\end{tabular}

PN - peso ao nascimento; PV35, PV41, PV42 - peso vivo aos 35, 41 e 42 dias, respectivamente; GP - ganho de peso dos 35 aos 42 dias; GP35, GP41 e GP42 - ganho de peso do nascimento aos 35, 41 e 42 dias, respectivamente; CA - conversão alimentar; EF eficiência alimentar; PA - peso da asa; PC - peso da coxa; PEIT - peso do peito; PPEIT - porcentagem de peito; CARR - peso da carcaça residual; CARC - peso da carcaça; PCARC - porcentagem de carcaça; GA - peso da gordura abdominal; PGA porcentagem de gordura; FI - peso do figado; COR - peso do coração; PU - peso do pulmão; MO - peso da moela; CI comprimento do intestino.

** significativo a $\mathrm{P} \leq 0,01,{ }^{*}$ significativo a $\mathrm{P} \leq 0,05,{ }^{\dagger}$ significativo a $\mathrm{P} \leq 0,10$.

Sabendo-se que a análise do modelo de um único gene para os genes da miostatina e MyoD não revelou qualquer associação genótipo-fenótipo, a análise multigênica confirmou este resultado, evidenciando o efeito de genótipo do loco T455C do gene da miogenina sobre algumas das características quantitativas de desempenho e carcaça. 
Os efeitos de interação entre os genótipos dos locos analisados dois a dois não foram estatisticamente significativos para nenhuma das características estudadas e portanto não fora incluídos no modelo.

A importância dos genes da miostatina e MyoD para o desenvolvimento muscular é evidente. Contudo, não houve associação dos polimorfismos estudados com nenhuma das características fenotípicas, no entanto vale ressaltar que muitos outros polimorfismos podem ser explorados em outras regiões destes genes, as quais estejam de fato exercendo uma maior influência sobre sua função biológica.

\subsubsection{Miostatina e o mapeamento de QTLs no cromossomo 7}

Apesar do polimorfismo do gene da miostatina avaliado neste trabalho não ter apresentado efeito significativo sobre as características quantitativas estudadas, resultados descritos na literatura sugerem que a miostatina ou outros genes presentes na mesma região cromossômica estão influenciando características quantitativas relacionadas não só ao desenvolvimento do tecido muscular como também do tecido adiposo. Em um estudo realizado por Zhiliang et al. (2003) com o gene da miostatina em frangos, polimorfismos presentes na região regulatória foram associados a características de peso e porcentagem da gordura abdominal, peso ao nascimento, peso e porcentagem de músculos peitorais. No cromossomo 7, QTLs para características de peso da gordura abdominal ajustado para peso de carcaça e gordura da pele ajustada para peso da gordura abdominal, foram mapeados por Ikeobi et al. (2002) entre os marcadores LEI0064 e ROS0019. Embora grande parte dos genes localizados entre estes marcadores não tenham sido identificados até o momento, sabe-se que o gene da miostatina se encontra próximo ao marcador LEI0064 (www.ensembl.org), situado na posição de $165 \mathrm{cM}$ do mapa genético consenso da galinha (poultry.mph.msu.edu). 


\subsubsection{MyoD e o mapeamento de QTLs no cromossomo 5}

O gene MyoD está situado no cromossomo 5, entre os marcadores ADL0247 e MCW0193 (www.ensembl.org) localizados nas posições de $34 \mathrm{cM}$ e $50 \mathrm{cM}$ do mapa genético consenso (poultry.mph.msu.edu), respectivamente. QTLs associados a peso da gordura abdominal, peso da gordura abdominal ajustado para peso da carcaça e gordura da pele ajustada para peso da gordura abdominal foram mapeados neste cromossomo (Ikeobi et al., 2002), porém nenhum QTL foi mapeado entre os marcadores que flanqueiam este gene. O marcador MYOD1, localizado na seqüência do gene não está presente no mapa de ligação consenso e até o momento não foi utilizado em estudos de mapeamento de QTL.

\subsubsection{Genotipagem seletiva na análise de genes candidatos}

A metodologia de genotipagem seletiva descrita por Lander \& Botstein (1989) e recomendada por Rothschild \& Soller (1999) para o estudo de associação de genes candidatos se mostrou inadequada para a identificação dos genes candidatos funcionais neste trabalho. Os resultados obtidos pelo teste qui-quadrado foram contraditórios àqueles obtidos pela análise de variância para todos os genes genotipados na geração F2, em especial para o gene da miostatina. O resultado obtido com este gene no teste quiquadrado sugeriu que o loco A4938G apresentava maior relevância por indicar diferença na freqüência do alelo $\mathrm{G}$ entre os grupos de animais leves e pesados $(\mathrm{P}=$ 0,089) segundo a distribuição da característica PV42. Porém, a análise de variância no modelo de único gene revelou um resultado inesperado, pois não apresentou qualquer tendência de associação dos genótipos com este caractere $(\mathrm{P}=0,9459)$. Possivelmente a redução do número de famílias genotipadas para a análise de variância pode ter levado a este resultado contraditório, uma vez que há a possibilidade de existir um efeito de interação entre família e genótipo. Entretanto, este efeito só poderia ser detectado com a genotipagem deste loco em todas as famílias. 


\subsubsection{Efeito da miogenina sobre as características de desempenho e carcaça}

A massa muscular de um indivíduo é determinada pelo número e tamanho das miofibras. O número de células precursoras do músculo é estabelecido ainda na fase pré-natal em que o desenvolvimento muscular é controlado por fatores miogênicos e de crescimento (Te Pas, 2004). Sendo assim, um indivíduo possui um número limitado de fibras musculares após o nascimento, momento a partir do qual o crescimento muscular é decorrente da hipertrofia das miofibras. No desenvolvimento muscular, a miogenina atua na fase de diferenciação dos mioblastos e sua expressão ocorre mediante a inibição da proliferação celular mediada pela miostatina, evento imprescindível para que possa haver diferenciação celular (Thomas et al., 2000). Este gene tem se revelado de grande importância na produção de carne devido ao fato da sua expressão limitar a proliferação de novas células precursoras durante a miogênese (Te Pas, 2004). Em estudos realizados com aves, embriões com maior capacidade de desenvolvimento muscular de uma linhagem selecionada para corte apresentaram um atraso na expressão deste gene quando comparados à linhagem de postura (Alvares, 2001). Este atraso poderia permitir que a proliferação celular continuasse por mais tempo, levando a um aumento no número de mioblastos e conseqüentemente do número de miofibras (Alvares, 2001). Estudos de associação deste gene com características quantitativas de desempenho e carcaça têm sido realizados em populações comerciais de suínos e têm mostrado que este gene apresenta efeitos significativos em uma série de caracteres de crescimento e carcaça (Te Pas et al., 1999; Te Pas, 2004).

O gene da miogenina está situado no microcromossomo 32, no qual QTLs não foram mapeados até o momento. No presente estudo, embora a miogenina tenha sido associada aos caracteres PV42 $(\mathrm{P}=0,0263), \mathrm{GP} 42(\mathrm{P}=0,0291), \mathrm{GP}(\mathrm{P}=0,0368)$, CARC $(P=0,0245), P A(P=0,0099)$, CARR $(P=0,0056)$ e $\mathrm{GA}(\mathrm{P}=0,0320)$, não é possível afirmar que este gene seja de fato responsável pelo seu efeito quantitativo. Sempre haverá a possibilidade de que o gene estudado não seja o gene que realmente esteja causando a diferença na característica, mas esteja somente ligado ao QTL (Rothschild \& Soller, 1999). Em geral, as características quantitativas são determinadas 
por muitos genes os quais podem exercer efeitos pleiotrópicos ou de epistasia. Muitas vezes, o estudo isolado de um único gene pode levar a resultados contraditórios quando analisados em populações diferentes, pois desconsidera todas as demais variáveis envolvidas na formação da característica. Deve-se destacar que as base genéticas envolvidas na variação das características quantitativas são complexas, o que dificulta a identificação vários genes os quais podem explicar grande parte da variação do caráter.

Associações de genes candidatos são tipicamente descobertas em gerações específicas de uma população específica. Conseqüentemente, há sempre a possibilidade de que os efeitos sejam limitados à determinada população, ou mesmo a uma determinada geração. Por exemplo, o gene candidato na população estudada pode estar em transiente desequilíbrio de ligação com um dos atuais QTLs, localizado a alguma distância deste, ou mesmo em outro cromossomo afetando a variação do fenótipo (Rothschild \& Soller, 1999). Quando o efeito do gene candidato é devido a um desequilíbrio de ligação com um gene próximo, este efeito pode-se limitar a uma determinada população. O mesmo pode acontecer se o efeito do gene candidato é causado pela interação de alelos com um background genético específico da população estudada (Rothschild \& Soller, 1999). Desta forma, apesar dos resultados obtidos com o marcador T455C da miogenina terem sido significativos, a validação deste polimorfismo como marcador deve ser confirmado em uma ou mais gerações futuras da mesma população, em outras populações da mesma linhagem ou mesmo em outras linhagens. Vale ressaltar que neste trabalho o marcador $\mathrm{T} 455 \mathrm{C}$ foi analisado dentro de uma população referência de delineamento experimental específico para que fosse alcançado um desequilíbrio de ligação entre os locos de interesse.

Deve-se considerar também que os locos estudados nos genes da miostatina e MyoD, assim como a miogenina podem revelar resultados diferentes se avaliados em outras populações. Desta forma, os resultados obtidos na avaliação dos efeitos destes polimorfismos como marcadores associados a características de desempenho e carcaça podem se aplicar somente à população estudada neste trabalho. 


\section{CONCLUSÃO}

- Foram identificados polimorfismos em fragmentos clonados dos genes da miostatina, Myf5, MRF4 e miogenina, e pelo seqüenciamento dos produtos de PCR do gene MyoD em parentais do cruzamento TC. Entretanto, não foi possível a validação destes nos genes Myf5 e MRF4.

- No gene da miostatina, nenhum dos polimorfismos detectados em clones foram validados em parentais do cruzamento TC, sendo que um novo polimorfismo denominado A4938G foi descoberto em parentais da linhagem CC de postura. No gene da miogenina foi possível validar quatro sítios polimórficos detectados previamente em clones, dos quais dois foram identificados somente em parentais da linhagem TT. No fragmento estudado do gene MyoD, foi validado um único polimorfismo caracterizado pela deleção de 13 pares de base, o qual foi encontrado somente em parentais da linhagem TT de corte.

- $\quad$ estudo dos polimorfismos validados dos genes MyoD, miogenina e miostatina resultou na identificação de um marcador no gene da miogenina, o qual apresentou efeito significativo na variação dos caracteres: peso vivo ao 42 dias, ganho de peso do nascimento aos 42 dias de idade, ganho de peso dos 35 aos 42 dias de idade, peso da carcaça, das asas, peso da carcaça residual, peso da gordura abdominal, fígado e pulmão. 
- Não foi verificado efeito de interação entre os genes MyoD, miogenina e miostatina sobre as características quantitativas. 
ANEXOS 
ANEXO A. Reações de PCR otimizadas para a genotpagem.

Reação otimizada para os primers MST2D/MST2R para temperatura de anelamente de $55^{\circ} \mathrm{C}$, utilizados na a genotipagem da miostatina.

\begin{tabular}{ll}
\hline Reagentes & $1 \times(25 \mu \mathrm{l})$ \\
\hline $\mathrm{H}_{2} \mathrm{O}_{\text {milia }}$ & $10,3 \mu \mathrm{l}$ \\
Tampão F $^{*}$ & $5,0 \mu \mathrm{l}$ \\
$\mathrm{P}_{\mathrm{D}}(2$ pmoles $/ \mu \mathrm{l})$ & $2,5 \mu \mathrm{l}$ \\
$\mathrm{P}_{\mathrm{R}}(2 \mathrm{pmoles} / \mu \mathrm{l})$ & $2,5 \mu \mathrm{l}$ \\
$\mathrm{dNTP}(10 \mathrm{mM})$ & $1,0 \mu \mathrm{l}$ \\
Taq polimerase & $0,2 \mu \mathrm{l}$ \\
DNA $(20 \mathrm{ng} / \mu \mathrm{l})$ & $5,0 \mu \mathrm{l}$ \\
\hline
\end{tabular}

* PCR Optimizer kit

Reação otimizada para os primers PD300/R10 para temperatura de anelamento de $58^{\circ} \mathrm{C}$, utilizados na genotipagem da miogenina.

\begin{tabular}{ll}
\hline Reagentes & $1 \mathrm{x}(25 \mu \mathrm{l})$ \\
\hline $\mathrm{H}_{2} \mathrm{O}_{\text {miliQ }}$ & $10,3 \mu \mathrm{l}$ \\
Tampão F $^{*}$ & $5,0 \mu \mathrm{l}$ \\
$\mathrm{P}_{\mathrm{D}}(2 \mathrm{pmoles} / \mu \mathrm{l})$ & $2,0 \mu \mathrm{l}$ \\
$\mathrm{P}_{\mathrm{R}}(2 \mathrm{pmoles} / \mu \mathrm{l})$ & $2,0 \mu \mathrm{l}$ \\
$\mathrm{dNTP}(10 \mathrm{mM})$ & $1,0 \mu \mathrm{l}$ \\
Taq polimerase & $0,2 \mu \mathrm{l}$ \\
DNA $(20 \mathrm{ng} / \mu \mathrm{l})$ & $5,0 \mu \mathrm{l}$ \\
* PCR Optimizer $k i t$ &
\end{tabular}

Reação otimizada para os primers PDMyoD3/PRMyoD para temperatura de anelamento de $65^{\circ} \mathrm{C}$, utilizados na genotipagem do gene MyoD.

\begin{tabular}{lc}
\hline Reagentes & $1 \times(25 \mu \mathrm{l})$ \\
\hline $\mathrm{H}_{2} \mathrm{O}_{\text {miliQ }}$ & $9,7 \mu \mathrm{l}$ \\
Tampão $10 \mathrm{x}$ & $2,5 \mu \mathrm{l}$ \\
$\mathrm{MgCl}_{2}(50 \mathrm{mM})$ & 2,0 \\
$\mathrm{P}_{\mathrm{D}}(2$ pmoles $/ \mu \mathrm{l})$ & $2,0 \mu \mathrm{l}$ \\
$\mathrm{P}_{\mathrm{R}}(2 \mathrm{pmoles} / \mu \mathrm{l})$ & $2,0 \mu \mathrm{l}$ \\
$\mathrm{dNTP}(10 \mathrm{mM})$ & $1,0 \mu \mathrm{l}$ \\
Taq polimerase & $0,3 \mu \mathrm{l}$ \\
DNA(20ng/ $\mu \mathrm{l})$ & $5,0 \mu \mathrm{l}$ \\
\hline
\end{tabular}


ANEXO B. Polimorfismos detectados pelo sequenciamentoe de clones do gene da miostatina.

Polimorfismos detectados no contig referente a extremidade 3'- 5' do gene da miostatina, o qual inclui 49 reads. A posição é referente a numeração da sequencia do contig.A identificação dos polimorfismos é referente a numeração dos nucleotídeos na sequencia completa do gene, disponível no GenBank sob ID - AF346599.

\section{Contig 1:}

CTGGGAATGTGACAGCAAGATCTCGTCCAGTCTCATCAAAAGCTTTTATTTCGATGCCTAAATTGGATTCAGGCTGTT TGAGCCAATTTTGCAGCACTGTCTTCACATCAATACTCTGCCAGATACCAGTGCCTGGGTTCATGTCAAGTTTCAAAG ATCGAATTCCAGTATATCTTGTACCGTCTTTCATGGGCTTAATGAGTCTCAGGATCTGCACAAACACCGTTGTAGGTTT TTGGACTTGCCTCAAGTATATCCATAATTGTGCCTTTACTACTTTGTTATATTGTATTTTAGAGCTAAACTTAAAGAAG CAACATTTTGGTTTTCCCTCCATTTGTACAAGAAAATCAGCTATAAATGAATGGAAAGAACAAATTACTGAACAGGG AACAAAAAGAAATATGCATATATAACCCAATTTTTTTCCAGATCATGTAGGATGTCTTACAATATTACATAAACTGTA TTGGTAACAGAGTGGATGCAATATCATTCAATTTCTGTACTTTACATTCTACAGCAAATCTAATCATTATGCTGTCACC TACAAGTAACATTCTGTGACAAGGAACTGATGGTTGTTTTGTAAGCAGGCTAAAAGAAAGTTTGGCTAACCATTTTCT AAGTAACTGTAGCTGATCCCTTGCGCTCTGTAGGCTATGCGGAGTGAGCGATGTGTACAGGCAGAAATTCAGGAATA TGATAGCAGAGAAAGAAAGCACTGCAGTGGGACCCC

\begin{tabular}{|l|l|l|l|l|l|c|}
\hline Identificação & Linhagem & Qualidade & Posição & Consenso & Mutante & Freqüência \\
\hline 4830 & CC & 57 & 41 & A & G & 1 \\
\hline 4789 & CC e TT & 57 & 82 & G & C & 2 \\
\hline 4770 & TT & 59 & 101 & C & T & 1 \\
\hline 4717 & TT & 52 & 154 & A & G & 1 \\
\hline 4600 & TT & 62 & 271 & T & C & 1 \\
\hline 4576 & TT & 43 & 295 & T & A & 1 \\
\hline 4571 & TT & 62 & 300 & C & T & 1 \\
\hline 4544 & TT & 62 & 329 & T & Deleção & 1 \\
\hline 4542 & TT & 57 & 331 & T & Deleção & 1 \\
\hline 4525 & TT & 68 & 346 & G & A & 1 \\
\hline 4405 & CC e TT & 59 & 466 & T & G & 14 \\
\hline 4360 & TT & 48 & 511 & T & C & 18 \\
\hline
\end{tabular}


Polimorfismos detectados no contig referente a extremidade 5'- 3'do gene da miostatina, o qual inclui 51 reads. A posição é referente a numeração da sequencia do contig.A identificação dos polimorfismos é referente a numeração do gene, disponível no GenBank sob ID - AF346599.

\section{Contig 2:}

AGGGCGTTTTGAATTTAGCCGCCGCGAATTCCCCCTTAGTAGCGATGGCTCTTTGGAAGACGATGACTATCATGCCAC AACCGAGACGATTATCACAATGCCTACGGAGTGTAAGTAACAACCCTGCTGCTTTCGTCTCGCACCGCTCCTCTGAGA GTTGTCTCTGTGCTGTAGAGCCTCACAACTCCTTCTCAGGCTCTCCCAACAGGCTGCTGGCTGGAGTCTGCCGGAGGG AGGGAGGAGAGTGTATTTCTAAAGGATTTGAGTCAGGTTCAAATGACCGTGCTGCAAGCCTTTGTTTTACTGTTCATT TGTTCGGCTCCTTGTAACGTGTGTGCCCTGTAGCACACTTAAGATTTGCCAATTGCTTTAGAAAGCAAAAGGAGATCC GCAGTTCAGTTGGCTCTGTTATTTGCGGCATTCAGGGCATTCCCTATTGCAGATAGAAATGCAAGTGCAGCTAATAAG ATAACTGTGTTTTTCTGCATGACATTCCACCTGCTGATGTGCTTAAGAGCAATAGAAACGAGTAGAAATACAGCTTAG AGCAGGGACCCGCTAAACTACAGCGTGTTACAGCAAGTGTAAGCATAGAGTTAAATCCTTGCTTCTCTGCTGATCCCA TGAGCCAGCACCACCCACCTCTAAGTTAAAACTATGTATTTAAAGCAGATCTACGTGTAACAGATTTAAATGCTAAAG TGTCCACATTATAGCAATCAGCTCCAGTAGTCGTGCCAAGGAAGAATGAGGCATTTACTGAATGAGCAGATTCTAGTT ATCTTCTTAGTGCTAACATCTGCTACG

\begin{tabular}{|l|l|l|l|l|l|c|}
\hline Identificação & Linhagem & Qualidade & Posição & Consenso & Mutante & Freqüência \\
\hline 2374 & CC e TT & 46 & 61 & C & T & 17 \\
\hline 2440 & TT & 57 & 127 & C & T & 3 \\
\hline 2489 & CC e TT & 44 & 176 & G & A & 3 \\
\hline 2740 & CC e TT & 57 & 427 & G & A & 3 \\
\hline 2841 & CC & 30 & 528 & G & A & 9 \\
\hline 2870 & CC e TT & 39 & 557 & C & T & 12 \\
\hline 2883 & TT & 43 & 570 & C & T & 3 \\
\hline
\end{tabular}


ANEXO C. Polimorfismos detectados pelo seqüenciamento de clones do gene da miogenina.

Polimorfismos detectados no contig 1 da extremidade 5', de cinco reads, do gene da miogenina. A posição é referente ao tamanho do fragmento seqüenciado.

\section{Contig 1:}

GGCCGCGAATTCGTCCTTAGGCTGAAGAAGGTGAACGAAGCCTTCGAGGCTCTGAAACGCAGCACTCTGCTCAACCC CAACCAGCGGCTGCCCAAGGTGGAGATCCTGCGCAGCGCCATCCAGTACATCGAGCGCCTGCAGAGCCTGCTCAGCA GCCTCAACCAGCAGGAGCGCGAGCAGAGGGAGCTGCGCTACCGCCCCGCTGCACCACAACCTGCTGTGAGTGTGGGG ATGGGTGGGGATGGGGGGCAGGAGCCGGGGTGGGTGGTGATGGAGGGACGGGGTGGTGATGCTCAGGTTGTTGTCC CTGTGGGCGGGTGTTGGTGGGTGATGGGCTGATGGCCGTTGCATTGAGCAGAGTGGGTTGGTGGTGCTTGGTGGGGA GTGGGAAGGCTTAAGTCGTAGAAATGATCGTAGAACCATGGGATCACAGAGCCATGGAATCATGGGGTCATAGAACC ATGGGATCATAGAGTCATGGAATCATGGAATCACAGAGACATGGAACCATGGGATCATAGAGTCGTGGAATCATGGA ATCACAGAGACATGGAACCATGGGATCATAGAGCCATGGAATCATGGGGTCATAGAGCCACGCAATCATACAGTCAC GGAATCATACAGTCATAAAATCATAGGACCATAGAATCATGGAATCATAGAACCATGGACTCACAGAACCATGGAAT CATGGCACCATAGGATGGGTGGGTTGGATCTCAAAGATCCTCCAGTTCCAATC

\begin{tabular}{|l|l|l|l|l|l|c|}
\hline Identificação & Linhagem & Qualidade & Posição & Consenso & Mutante & Freqüência \\
\hline miog_1 & TT & 54 & 84 & G & A & 1 \\
\hline miog_2 & TT & 54 & 113 & G & A & 1 \\
\hline miog_3 & CC & 43 & 150 & C & T & 1 \\
\hline miog_4 & CC & 43 & 239 & G & A & 1 \\
\hline miog_5 & CC & 52 & 349 & C & T & 1 \\
\hline miog_6 & TT & 35 & 513 & G & A & 1 \\
\hline miog_7 & CC & 37 & 628 & T & C & 1 \\
\hline
\end{tabular}

Polimorfismos detectados nno contig 2 da extremidade 5', de sete reads, do gene da miogenina. A posição é referente ao tamanho do fragmento seqüenciado.

\section{Contig 2:}

GGCTGAAGAAGGTGAACGAAGCCTTCGAGGCTCTGAAACGCAGCACTCTGCTCAACCCCAACCAGCGGCTGCCCAAG GTGGAGATCCTGCGCAGCGCCATCCAGTACATCGAGCGCCTGCAGAGCCTGCTCAGCAGCCTCAACCAGCAGGAGCG CGAGCAGAGGGAGCTGCGCTACCGCCCCGCTGCACCACAACCTGCTGTGAGTGTGGGGATGGGTGGGGATGGGGGG CAGGAGCCGGGGTGGGTGGTGATGGAGGGACGGGGTGGTGATGCTCAGGTTGTTGTCCCTGTGGGCGGGTGTTGGTG GGTGATGGGCTGATGGCCGTTGCATTGAGCAGAGTGGGTTGGTGGTGCTTGGTGGGGAGTGGGAAGGCTTAAGTCGT AGAAATGATCGTAGAACCATGGGATCACAGAGCCATGGAATCATGGGGTCATAGAACCATGGGATCACAGAGCCAT GGAATCATGGGGTCATAGAACCATGGGATCACAGAGCCATGGAATCATGGGGTCATAGAACCATGGGATCACAGAG CCATGGAATCATGGGGTCATAGAACCATGGGATCATAGAGTCATGGAATCATGGAATCACAG 


\begin{tabular}{|l|l|l|l|l|l|c|}
\hline Identificação & Linhagem & Qualidade & Posição & Consenso & Mutante & Freqüência \\
\hline miog_8 & TT & 48 & 58 & C & T & 1 \\
\hline miog_9 & CC & 57 & 91 & G & A & 1 \\
\hline miog_10 & CC & 52 & 155 & C & T & 3 \\
\hline miog_11 & TT & 57 & 171 & C & T & 1 \\
\hline miog_12 & TT & 57 & 238 & C & T & 2 \\
\hline miog_13 & CC & 50 & 283 & T & C & 1 \\
\hline miog_14 & CC & 57 & 293 & G & A & 1 \\
\hline miog_15 & CC & 46 & 486 & G & T & 1 \\
\hline
\end{tabular}

Polimorfismos detectados nno contig 3 da extremidade 3', de 39 reads, do gene da miogenina. A posição é referente ao tamanho do fragmento seqüenciado.

\section{Contig 3:}

GGCCGCGAATTCGCCCTTCACAGTGTCGGAGGGGTAATTATGATTTCCAGCTGCTGGATCCTTCCAGCATCACCATCC CACCCCGTTTCCAGCTCAGAGAGCCGCGGGGCTTTGCGCCAGCTCAGTTTTGGACCCGCTCCTCTGGGAACGTCACGG CCACGTCCTCCACGGCGATGCTCTCCACGATGGAGGAGAGCGAGTGGAGGTTGCGGTCCTCTGCCTGGTCATCGCTCA GGAGGTGATCTGAGAGAGGAGGGGGAGGGCAATGGGATGGTGACCCCACGACCCTACTCTGTGTGACCGCACTGAT GTGGGGATCCGCTCCCAGATCCCGTCCTGAGGACTGAGACCTTTCCCCAGAGGTGGCAACGGGCAGTGAAACTTGGG GAAGCTTTTAGGGGGTGGGAGAGGCAGCTCTGTGCGGGTGCTCTGTGCTGCAGGGCTGGGCTATGGGGCAGGCACAG ATGAACCCTTAATGGGACAGGGATGTGGAGCTGCTGCAGGCTGCTTCCAGCACATCAGGCAATGGGAGAAGCCTGAG TGCGCTCAAGGAGTGCTGGAGGGTTCACCCAACAGTGGGGTGGGGGGAGGACAAGGGTCCTCCTGTCCCCTGGCTGT GGGTTTTGGTTCAGGGATGCTCACCCCCACCACTGTGGTGTCCCTGAAATGGATGCTGAG

\begin{tabular}{|l|l|l|l|l|l|c|}
\hline Identificação & Linhagem & Qualidade & Posição & Consenso & Mutante & Freqüência \\
\hline $\operatorname{miog} 18$ & CC & 57 & 124 & T & C & 1 \\
\hline $\operatorname{miog} 19$ & CC & 41 & 129 & A & C & 1 \\
\hline miog_20 & CC & 52 & 136 & C & T & 1 \\
\hline $\operatorname{miog} 21$ & CC & 43 & 140 & G & A & 1 \\
\hline $\operatorname{miog} 22$ & TT & 57 & 149 & G & C & 1 \\
\hline $\operatorname{miog} 23$ & CC & 62 & 155 & C & T & 1 \\
\hline miog_24 & CC & 52 & 156 & C & T & 2 \\
\hline miog_25 & TT & 57 & 196 & C & A & 1 \\
\hline miog_26 & TT & 62 & 209 & C & T & 1 \\
\hline miog_27 & CC & 43 & 215 & G & A & 2 \\
\hline miog_28 & TT & 57 & 219 & C & T & 2 \\
\hline miog_29 & TT & 62 & 224 & C & G & 1 \\
\hline
\end{tabular}


Polimorfismos detectados no contig 4 da extremidade 3', de 76 reads, do gene da miogenina. A posição é referente ao tamanho do fragmento seqüenciado.

\section{Contig 4:}

CCGGCCGCGAATTCGCCCTTCACAGTGTCGGAGGGGTAATTATGATTTCCAGCTGCTGGATCCTTCCAGCATCACCAT CCCACCCCGTTTCCAGCTCAGAGAGCCGCGGGGCTTTGCGCCAGCTCAGTTTTGGACCCGCTCCTCTGGGAACGTCAC GGCCACGTCCTCCACGGCGATGCTCTCCACGATGGAGGAGAGCGAGTGGAGGTTGCGGTCCTCTGCCTGGTCGTCGCT CAGGAGGTGATCTGAGAGAGGAGGGGGAGGGCAATGGGATGGTGACCCCACGACCCTACTCTGTGTGACCACACTG ATGTGGGGATCCGCTCCCAGATTCCGTCCTGAGGGCTGAGACCTTTCCCCAGAGATGGCAACGGGCAGTGAAACTTG GGGAAGCTTTTAGGGGGTGGGAGAGGCAGCTCTGTGCGGGTGCTCTGTGCTGCAGGGCTGGGCTATGGGGCAGGCAC AGATGAACCCTTAATGGGACAGGGATGTGGAGCTGCTGCAGGCTGCTTCCAGCACATCAGGCAATGGGAGAAGCCTG AGTGCGCTCAAGGAGTGCTGGAGGGTTCACCCAACAGTGGGGTGGGGGGGAGGACAAGGGTCCTCCTGTCCCCTGGC TGTGGGTTTTGGTTCAGGGATGCTCACCCCCACCACTGTGGTGTCCCTGAGATGGATGCTGAGGAAGGGGAGTTCCTT ACCTGCGGGG

\begin{tabular}{|l|l|l|l|l|l|c|}
\hline Identificação & Linhagem & Qualidade & Posição & Consenso & Mutante & Freqüência \\
\hline miog_30 & TT & 54 & 145 & A & G & 1 \\
\hline miog_31 & TT & 54 & 150 & T & C & 1 \\
\hline miog_32 & TT & 57 & 152 & C & T & 1 \\
\hline miog_33 & TT & 33 & 174 & G & A & 1 \\
\hline miog_34 & TT & 62 & 179 & G & A & 2 \\
\hline miog_35 & TT & 35 & 203 & A & G & 1 \\
\hline miog_36 & TT & 52 & 216 & G & A & 1 \\
\hline miog_37 & TT & 57 & 225 & C & T & 1 \\
\hline miog_38 & TT & 27 & 229 & C & T & 2 \\
\hline miog_39 & TT & 42 & 242 & A & G & 1 \\
\hline
\end{tabular}

Os polimorfismos miog_19, miog_23 e miog_24 também foram detectados neste contig, todos na linhagem TT, e portanto não foram listados novamente. 
ANEXO D. Polimorfismos detectados pelo seqüenciamento de clones do gene MRF4.

Polimorfismos detectados no contig da extremidade 5'- 3' de 9 reads, do gene MRF4. A posição do polimorfismo é dada em referência a numeração das bases do contig.

\section{Contig 1:}

CGCGAATTCGCCCTTGGTGGTTTGTGGGTCAAAACTTCGAGAAAACAAAACGGGAGATGCGGAGAGGGGTGAGGAA AGAGTCCGTGCGGCTCGGGTCTCCGAGGGCCGTTCCGCCGGGGGGAGCGTGCCCCGAGGCGGCCGCGGCGCCGCGCC GCTCATTTCTCCACCGCTTCTTCCGCGCCGGGCAGCTTGGGCTCGTCGGAGGAAATGCTGTCCACGATGGAGGAGAGG CAGCGCAGACTGCTGGAGGCCGACGACTCCACCATGGAGCCCCCTGCTCGGCGGGAGAGAGGGGTTAGGGAGCGGG CGCGGCCGGCAACGAGGCCGCGGGGAGCCGCCGCAGGGGCGGGAGCGCCGGGCTGTGAGCGAGCGCCGGGCGCGGC GGCCGTTACCTGCTTTGGGGCTGCCCCCCAACGCGCGGGAATGGTCGGAAGCGCTGTGCCAGTCGGAGCCGCAGGTG CTCAGGAAGTCGGAGCCGGGGACCTGCGGCGGGGCGCGGGGAGAGGGGACGCTGCGTTAGCGAGGCGAGCGGCGGC GGGGCGCGCACGTTACCCCAACCCCCCTTCCCGCCCCTGCGCTTCCCCCCCCACCCCCC

\begin{tabular}{|l|l|l|l|l|l|c|}
\hline Identificação & Linhagem & Qualidade & Posição & Consenso & Mutante & Freqüência \\
\hline mrf4_1 & CC & 37 & 60 & G & A & 2 \\
\hline mrf4_2 & CC & 48 & 64 & A & T & 2 \\
\hline mrf4_3 & CC & 59 & 88 & C & T & 2 \\
\hline mrf4_4 & CC & 54 & 232 & G & A & 2 \\
\hline mrf4_5 & CC & 62 & 285 & G & A & 2 \\
\hline mrf4_6 & CC & 52 & 294 & G & A & 1 \\
\hline mrf4_7 & CC & 57 & 326 & C & T & 1 \\
\hline mrf4_8 & CC & 57 & 331 & G & T & 1 \\
\hline mrf4_9 & CC & 57 & 347 & G & T & 4 \\
\hline mrf4_10 & CC & 43 & 453 & C & T & 2 \\
\hline
\end{tabular}


Polimorfismos detectados no contig 2 da extremidade 3'- 5' de 205 reads, do gene MRF4. A posição do polimorfismo é dada em referência a numeração das bases do contig.

\section{Contig 2:}

GTTTAAACGCGAATTCGCCCTTGGTGGTCTGTGGGTCAAAACTTCGAGAAAACAAAACGGGAGATACGGTGAGGGGT GAGGAAAGAGTCCGTGCGGCTCGGGTCTCCGAGGGCCGTTCCGCCGGGGGGAGCGTGCCCCGAGGCGGCCGCGCCG CCGCGACGCTCATTTCTCCACCGCCTCTTCCGCGCCGGGCAGCTTGGGCTCGTCGGAGGAAATGCTGTCCACGATGGA GGAGAGGCAGCGCAGGCTGCTGGAGGCCGACGACTCCACCATGGAGCCCCCTGCTCGGCGGGAGAGAGGGGTTAGG GAGCGGGCGCGGCCGGCAACGAGGCCGCGGGGAGCCGCCGCTGGGGCGGGAGCGCCGGGCTGTGAGCGAGCGCCGG GCGCGGCGGCCGTTACCTGCTTTGGGGCTGCCCCCCAGCGCGCGGGAATGGTCGGAAGCGCTGTGCCAGTCGGAGCC GCAGGTGCTCAGGAAGTCGGAGCCGGGGACCTGCGGCGGGGCGCGGGGAGAGGGGACGCTGCGTTAGCGAGGCGAG CGGCGGCGGGGCGCGCACGTTACCCCAACCCCCCTTCCCGCCCCTGCGCTCCCCCCCCCACCCCCCCGCGGCCGTCAG CCCCCTGTCGGGGGGAGGAGGAGGGGAAGGAGGGAGGGGAGCGCGGGCCCGCAGCTGGGTGCCGCAGGGAGCGGG CCGCCGCCGTGCTTACGTTTCCCTGCTTGGGGCTGAAGCTGAAGGGGTCCGCCGCCACCTCCTGCATTTTGTCCTAAG GGCGAATTCGCGG

\begin{tabular}{|l|l|l|l|l|l|c|}
\hline Identificação & Linhagem & Qualidade & Posição & Consenso & Mutante & Freqüência \\
\hline mrf4_11 & TT & 57 & 74 & G & T & 3 \\
\hline mrf4_12 & CC e TT & 68 & 107 & C & G & 9 \\
\hline mrf4_13 & CC e TT & 41 & 108 & G & A & 9 \\
\hline mrf4_14 & CC e TT & 68 & 109 & A & G & 7 \\
\hline mrf4_15 & TT & 68 & 121 & C & T & 3 \\
\hline mrf4_16 & CC & 43 & 130 & G & A & 4 \\
\hline mrf4_17 & CC e TT & 53 & 147 & C & G & 3 \\
\hline mrf4_18 & CC & 68 & 151 & C & G & 6 \\
\hline mrf4_19 & CC e TT & 68 & 169 & C & A & 6 \\
\hline mrf4_20 & TT & 57 & 173 & A & G & 3 \\
\hline mrf4_21 & TT & 68 & 176 & G & A & 4 \\
\hline mrf4_22 & CC & 43 & 178 & C & T & 7 \\
\hline mrf4_23 & CC e TT & 68 & 189 & C & G & 6 \\
\hline mrf4_24 & CC e TT & 48 & 192 & G & A & 4 \\
\hline mrf4_25 & CC e TT & 68 & 193 & C & T & 3 \\
\hline mrf4_26 & CC & 44 & 195 & G & A & 5 \\
\hline mrf4_27 & CC e TT & 68 & 196 & C & G & 5 \\
\hline mrf4_28 & CC e TT & 41 & 202 & C & T & 3 \\
\hline mrf4_29 & CC e TT & 59 & 224 & A & T & 3 \\
\hline mrf4_30 & CC & 50 & 238 & G & A & 4 \\
\hline mrf4_31 & CC & 57 & 239 & C & T & 5 \\
\hline mrf4_32 & CC e TT & 68 & 247 & G & A & 11 \\
\hline mrf4_33 & CC e TT & 41 & 250 & G & T & 4 \\
\hline
\end{tabular}




\begin{tabular}{|c|c|c|c|c|c|c|}
\hline Identificação & Linhagem & Qualidade & Posição & Consenso & \begin{tabular}{|l|} 
Mutante \\
\end{tabular} & Freqüência \\
\hline mrf4_34 & TT & 57 & 258 & $\mathrm{C}$ & $\mathrm{T}$ & 3 \\
\hline mrf4 35 & $\mathrm{CC}$ e TT & 50 & 260 & $\mathrm{G}$ & $\mathrm{T}$ & 3 \\
\hline mrf4_36 & $\mathrm{CC} \mathrm{e} \mathrm{TT}$ & 57 & 261 & $\mathrm{~A}$ & $\mathrm{~T}$ & 5 \\
\hline mrf4_37 & $\mathrm{CC}$ & 57 & 265 & $\mathrm{C}$ & $\mathrm{G}$ & 4 \\
\hline mrf4_38 & $\mathrm{CC}$ & 68 & 266 & $\mathrm{~T}$ & $\mathrm{G}$ & 7 \\
\hline mrf4_39 & $\mathrm{CC}$ & 59 & 279 & $\mathrm{C}$ & $\mathrm{A}$ & 4 \\
\hline mrf4 40 & TT & 68 & 301 & $G$ & $\mathrm{~T}$ & 3 \\
\hline mrf4_41 & TT & 50 & 307 & $\mathrm{G}$ & $\mathrm{A}$ & 4 \\
\hline mrf4_42 & TT & 68 & 310 & $\mathrm{G}$ & $\mathrm{A}$ & 4 \\
\hline mrf4 43 & $\mathrm{CC}$ e TT & 42 & 311 & $\mathrm{C}$ & $\mathrm{T}$ & 3 \\
\hline mrf4_44 & TT & 68 & 320 & $\mathrm{C}$ & $\mathrm{T}$ & 3 \\
\hline mrf4 45 & $\mathrm{CC}$ & 57 & 323 & $\mathrm{G}$ & $\mathrm{A}$ & 3 \\
\hline mrf4_46 & TT & 57 & 327 & $\mathrm{C}$ & $\mathrm{T}$ & 4 \\
\hline mrf4_47 & $\mathrm{CC}$ e TT & 50 & 328 & $\mathrm{G}$ & $\mathrm{A}$ & 6 \\
\hline mrf4_48 & $\mathrm{CC}$ & 59 & 331 & $\mathrm{G}$ & $\mathrm{A}$ & 3 \\
\hline mrf4 49 & $\mathrm{CC}$ & 48 & 332 & $\mathrm{C}$ & $\mathrm{T}$ & 3 \\
\hline mrf4_50 & $\mathrm{CC}$ e TT & 59 & 334 & $\mathrm{G}$ & $\mathrm{T}$ & 3 \\
\hline mrf4_51 & $\mathrm{CC}$ e TT & 57 & 339 & $\mathrm{G}$ & $\mathrm{A}$ & 8 \\
\hline mrf4_52 & $\mathrm{CC}$ e TT & 68 & 344 & $\mathrm{G}$ & $\mathrm{A}$ & 8 \\
\hline mrf4_53 & $\mathrm{CC}$ e TT & 52 & 349 & $\mathrm{~T}$ & A & 8 \\
\hline mrf4 54 & $\mathrm{CC}$ e TT & 68 & 353 & $\mathrm{G}$ & $\mathrm{T}$ & 3 \\
\hline mrf4_55 & $\mathrm{CC}$ e TT & 68 & 354 & $\mathrm{C}$ & $\mathrm{T}$ & 3 \\
\hline mrf4_56 & $\mathrm{CC}$ e TT & 68 & 374 & $\mathrm{C}$ & $\mathrm{T}$ & 10 \\
\hline mrf4_57 & CC e TT & 68 & 379 & $G$ & $\mathrm{~A}$ & 5 \\
\hline mrf4_58 & $\mathrm{CC}$ e TT & 57 & 380 & $\mathrm{C}$ & $\mathrm{T}$ & 4 \\
\hline mrf4_59 & TT & 57 & 385 & $\mathrm{C}$ & $\mathrm{A}$ & 3 \\
\hline mrf4_60 & $\mathrm{CC}$ e TT & 51 & 386 & $\mathrm{G}$ & $\mathrm{C}$ & 3 \\
\hline mrf4_61 & $\mathrm{CC}$ & 68 & 390 & $\mathrm{C}$ & $\mathrm{T}$ & 3 \\
\hline mrf4_62 & $\mathrm{CC}$ e TT & 51 & 392 & $\mathrm{G}$ & $\mathrm{A}$ & 4 \\
\hline mrf4_63 & $\mathrm{CC}$ e TT & 68 & 400 & $\mathrm{C}$ & $\mathrm{A}$ & 5 \\
\hline mrf4_64 & $\mathrm{CC}$ e TT & 50 & 402 & $\mathrm{G}$ & $\mathrm{A}$ & 5 \\
\hline mrf4_65 & $\mathrm{CC}$ e TT & 68 & 410 & $\mathrm{G}$ & $\mathrm{A}$ & 8 \\
\hline mrf4_66 & $\mathrm{CC}$ e TT & 54 & 411 & $\mathrm{C}$ & A & 6 \\
\hline mrf4_67 & $\mathrm{CC}$ e TT & 68 & 421 & $\mathrm{G}$ & A & 9 \\
\hline mrf4_68 & TT & 50 & 426 & $\mathrm{C}$ & $\mathrm{A}$ & 3 \\
\hline mrf4_69 & $\mathrm{CC}$ e TT & 62 & 438 & $\mathrm{G}$ & $\mathrm{A}$ & 4 \\
\hline mrf4_70 & $\mathrm{CC}$ e TT & 57 & 454 & $\mathrm{C}$ & $\mathrm{G}$ & 3 \\
\hline mrf4 71 & $\mathrm{CC}$ e TT & 57 & 459 & C & $\mathrm{T}$ & 3 \\
\hline mrf4 72 & $\mathrm{CC}$ e TT & 68 & 468 & $\mathrm{C}$ & $\mathrm{T}$ & 11 \\
\hline mrf4_73 & TT & 68 & 472 & $G$ & $\mathrm{C}$ & 5 \\
\hline mrf4_ 74 & $\mathrm{CC}$ e TT & 41 & 473 & $\mathrm{G}$ & $\mathrm{A}$ & 3 \\
\hline mrf4_75 & TT & 62 & 476 & $\mathrm{G}$ & $\mathrm{A}$ & 4 \\
\hline
\end{tabular}




\begin{tabular}{|l|l|l|l|l|l|c|}
\hline Identificação & Linhagem & Qualidade & Posição & Consenso & Mutante & Freqüência \\
\hline mrf4_76 & CC e TT & 48 & 482 & G & A & 3 \\
\hline mrf4_77 & CC e TT & 68 & 483 & C & T & 7 \\
\hline mrf4_78 & CC e TT & 57 & 493 & G & A & 6 \\
\hline mrf4_79 & TT & 47 & 494 & C & T & 5 \\
\hline mrf4_80 & TT & 57 & 502 & C & T & 5 \\
\hline mrf4_81 & CC e TT & 52 & 503 & G & T & 3 \\
\hline mrf4_82 & TT & 57 & 516 & A & G & 3 \\
\hline mrf4_83 & CC e TT & 59 & 522 & C & T & 4 \\
\hline mrf4_84 & CC e TT & 57 & 539 & G & A & 3 \\
\hline mrf4_85 & CC e TT & 68 & 542 & G & A & 5 \\
\hline mrf4_86 & CC & 48 & 550 & C & T & 3 \\
\hline mrf4_87 & CC & 48 & 554 & C & A & 4 \\
\hline mrf4_88 & TT & 54 & 569 & C & T & 3 \\
\hline mrf4_89 & CC e TT & 59 & 580 & C & A & 10 \\
\hline mrf4_90 & CC e TT & 50 & 585 & C & A & 9 \\
\hline mrf4_91 & CC e TT & 48 & 586 & T & C & 6 \\
\hline mrf4_92 & CC e TT & 47 & 588 & C & G & 3 \\
\hline mrf4_93 & CC e TT & 57 & 594 & C & A & 4 \\
\hline mrf4_94 & CC e TT & 57 & 597 & C & A & 3 \\
\hline mrf4_95 & CC e TT & 57 & 662 & C & T & 5 \\
\hline mrf4_96 & CC & 43 & 732 & A & G & 3 \\
\hline mrf4_97 & CC & 57 & 735 & G & T & 3 \\
\hline mrf4_98 & CC e TT & 57 & 739 & C & G & 5 \\
\hline mrf4_99 & CC & 48 & 743 & G & T & 4 \\
\hline mrf4_100 & TT & 41 & 756 & T & A & 4 \\
\hline
\end{tabular}


ANEXO C. Polimorfismos detectados pelo seqüenciamento de clones do gene Myf5.

Polimorfismos detectados no contig gerado pelo seqüenciamento da extremidade 5' - 3' de 42 reads, do gene Myf5. A posição dos polimorfismos é dada em referência a numeração das bases do contig.

\section{Contig:}

GGCCGCGAATTCGCCCTTGGTACATCGAAAGCTTCCAGGAGCTCTTGAGGGAACAGGTGGAGAACTACTATCACCTG CCGGGACAGAGCTGCTCCGAGCCCACCAGCCCCAGCTCCAGCTGCTCCGATGTGATGGTAAGAGCAGGGCAGGGTGA GGGGCAGCTCACGATGGGCTCGAGCAAGGGCCCTCGGTTTTGGGACTTCGGGAAAAGGTGGATAGCTTGGGTTAAAT CTCAAAAATGTTGGACGGTTTGGGTTCCCACCGGCTCTTTCTTGGAGCTGAGCGTGCACATGGGCTTTGGGGCACCCA ACACGCGCCCCGGCCCCTGCTCGCCCTTTGTCCCCCTGCTTGGGGCCGTGCGTGGGGAGGGAGGCGCGACCCGGCTG GAGCTCTACCGGGACGCTTCGGGGGGCTGCGGGGGCGGACGGGCCGGCACTGGCCCCTCGCTGTCTTGCAGGCGGAC TGCGGCAGCCCGGTCTGGCCGGCGAGAGGCAGCAGCTTCGAGGCGGGCTACTGCCCCGAGATGCCCCACGGTAAGGC CGGCGGCGGGCGGGGGGCCGGGGGCGGCCGGCGGGCGGGGGTCGCGGCTGGGCGGCCCGCGGTAAGCGGCTCGCCC CGGTGCCAGGCTACGCGACGGAGCAGAGTGGCGCGCTGTCCAGCCTGGACTGCCTCTCCAGCATCGTGGACCGCCTC TCTCCGGCGGAGGAGCCGGGGCTGCCCCTCCGTCACGCCGGCTCCCTCTCGCCAGGCGCCAGCATCGACTCGGGGCC CGGGACGCCCGGCTCGCCGCCGCCCCGACGGACCTACCAGGCGCTATGAGGGGCCGGGGCCACCGCCGGTTCAAAAA ATGACCCCGGCTGCCTCTCGTCCCGCCGCCCCGCAAAACCTCTCGGGCGGGAGGGAAAACCCCGGCTCCGCTGCCGT CGGGGTTGGAGGCGACGCCGCCGCCCGGAGCAGCCCCCGGGGCTCGGGACGCGTGTGCTGCCGTGGAAACCCCGCTG CAAAAAAAGCGTGCTACCAAAGGGCGAATTCGCGG

\begin{tabular}{|l|l|l|l|l|l|c|}
\hline Identificação & Linhagem & Qualidade & Posição & Consenso & Mutante & Freqüência \\
\hline 680 & TT & 53 & 176 & G & A & 4 \\
\hline 690 & TT & 68 & 186 & C & T & 4 \\
\hline 696 & CC e TT & 39 & 192 & T & C & 4 \\
\hline 697 & CC e TT & 20 & 193 & T & A & 4 \\
\hline 698 & CC e TT & 41 & 194 & T & G & 4 \\
\hline 726 & TT & 32 & 222 & T & G & 2 \\
\hline 733 & CC & 48 & 229 & A & T & 2 \\
\hline 756 & TT & 28 & 252 & T & G & 2 \\
\hline 800 & CC e TT & 68 & 296 & C & A & 2 \\
\hline 847 & CC e TT & 25 & 354 & G & A & 2 \\
\hline 883 & TT & 28 & 381 & C & T & 2 \\
\hline 891 & CC e TT & 57 & 389 & G & C & 2 \\
\hline 916 & TT & 68 & 415 & G & A & 2 \\
\hline 923 & CC e TT & 59 & 422 & C & A & 4 \\
\hline 930 & CC e TT & 68 & 429 & G & A & 2 \\
\hline 965 & CC e TT & 37 & 463 & C & G & 2 \\
\hline
\end{tabular}




\begin{tabular}{|l|l|l|l|l|l|c|}
\hline Identificação & Linhagem & Qualidade & Posição & Consenso & Mutante & Freqüência \\
\hline 1021 & TT & 30 & 519 & C & G & 5 \\
\hline 1045 & CC e TT & 41 & 543 & G & A & 2 \\
\hline 1046 & TT & 59 & 544 & C & A & 2 \\
\hline 1059 & TT & 36 & 557 & G & A & 2 \\
\hline
\end{tabular}


ANEXO F. Valores de probabilidade $\mathrm{F}$ da nálise de variância dos polimorfirmos miog_13, miog_16 e dos haplótipos obtidos pela análise dos três locos validados.

Valores de probabilidade do teste $\mathrm{F}$, coeficiente de variação (CV), coeficiente de determinação $\left(\mathrm{R}^{2}\right)$ de acordo com o modelo de um único gene para o loco miog_13 da miogenina.

\begin{tabular}{|c|c|c|c|}
\hline Caracteres & $\mathrm{CV}$ & Probabilidade & $\mathrm{R}^{2}$ \\
\hline PN & 4,14 & 0,9257 & 0,8823 \\
\hline PV35 & 9,89 & 0,9983 & 0,5275 \\
\hline PV41 & 9,21 & 0,8612 & 0,6063 \\
\hline PV42 & 9,34 & 0,7530 & 0,6167 \\
\hline GP & 15,30 & 0,5205 & 0,5899 \\
\hline GP35 & 10,44 & 0,9893 & 0,5283 \\
\hline GP41 & 9,62 & 0,8509 & 0,6047 \\
\hline GP42 & 9,77 & 0,7428 & 0,6144 \\
\hline $\mathrm{CA}$ & 12,85 & 0,7826 & 0,3620 \\
\hline $\mathrm{EF}$ & 12,40 & 0,9991 & 0,3713 \\
\hline $\mathrm{PA}$ & 9,07 & 0,3995 & 0,6189 \\
\hline $\mathrm{PC}$ & 12,10 & 0,9119 & 0,5809 \\
\hline PEIT & 11,80 & 0,7710 & 0,5634 \\
\hline PPEIT & 5,08 & 0,7924 & 0,5951 \\
\hline CARR & 12,29 & 0,5963 & 0,5279 \\
\hline CARC & 29,21 & 0,2652 & 0,4617 \\
\hline PCARC & 24,38 & 0,3516 & 0,4843 \\
\hline GA & 10,77 & 0,8480 & 0,5941 \\
\hline PGA & 2,86 & 0,6540 & 0,2985 \\
\hline FI & 13,59 & 0,2670 & 0,3273 \\
\hline COR & 17,25 & 0,3735 & 0,4961 \\
\hline PU & 22,56 & 0,4630 & 0,2810 \\
\hline $\mathrm{MO}$ & 11,19 & 0,1018 & 0,4372 \\
\hline $\mathrm{CI}$ & 7,01 & 0,6811 & 0,3403 \\
\hline
\end{tabular}


Valores de probabilidade do teste $\mathrm{F}$, coeficiente de variação (CV), coeficiente de determinação $\left(\mathrm{R}^{2}\right)$ de acordo com o modelo de um único gene para o loco miog_16 da miogenina.

\begin{tabular}{lccc}
\hline Caracteres & CV & Probabilidade & $\mathrm{R}^{2}$ \\
\hline PN & 4,04 & 0,1018 & 0,8877 \\
PV35 & 9,84 & 0,3990 & 0,5323 \\
PV41 & 9,13 & 0,2502 & 0,6136 \\
PV42 & 9,21 & 0,1527 & 0,6273 \\
GP & 15,14 & 0,1686 & 0,5984 \\
GP35 & 10,40 & 0,4358 & 0,5324 \\
GP41 & 0,2733 & 0,6112 \\
GP42 & 9,54 & 0,1693 & 0,6242 \\
CA & 9,64 & 0,0702 & 0,38997 \\
EF & 12,57 & 0,0397 & 0,4074 \\
PA & 12,04 & 0,1207 & 0,6278 \\
PC & 8,96 & 0,1156 & 0,5951 \\
PEIT & 11,89 & 0,2864 & 0,5699 \\
PPEIT & 11,71 & 0,9346 & 0,5947 \\
CARR & 5,08 & 0,0859 & 0,5457 \\
CARC & 12,06 & 0,5240 & 0,4553 \\
PCARC & 29,38 & 0,7803 & 0,4786 \\
GA & 24,51 & 0,1308 & 0,6070 \\
PGA & 10,60 & 0,2700 & 0,3083 \\
FI & 2,84 & 0,2528 & 0,3280 \\
COR & 13,58 & 0,1474 & 0,5062 \\
PU & 17,08 & 0,3952 & 0,2828 \\
MO & 22,54 & 0,3193 & 0,4237 \\
CI & 11,33 & 0,2514 & 0,3508 \\
\hline
\end{tabular}

PN - peso ao nascimento; PV35, PV41, PV42 - peso vivo aos 35, 41 e 42 dias, respectivamente; GP - ganho de peso dos 35 aos 42 dias; GP35, GP41 e GP42 - ganho de peso do nascimento aos 35, 41 e 42 dias, respectivamente; CA - conversão alimentar; EF eficiência alimentar; PA - peso da asa; PC - peso da coxa; PEIT - peso do peito; PPEIT - porcentagem de peito; CARR - peso das costelas; CARC - peso da carcaça; PCARC - porcentagem de carcaça; GA - peso da gordura abdominal; PGA -porcentagem de gordura; FI - peso do figado; COR - peso do coração; PU - peso do pulmão; MO - peso da moela; CI - comprimento do intestino.

** significativo a $\mathrm{P} \leq 0,01 ;$ * significativo a $\mathrm{P} \leq 0,05$ e ${ }^{\dagger}$ significativo a $\mathrm{P} \leq 0,10$. 
Valores de probabilidade do teste $\mathrm{F}$, coeficiente de variação $(\mathrm{CV})$, coeficiente de determinação $\left(\mathrm{R}^{2}\right)$ da análise de variância dos haplótipos, levando-se em consideração os três locos da miogenina. Ao todo foram encontrados cinco genótipos na população.

\begin{tabular}{lccc}
\hline Caracteres & CV & Probabilidade & $\mathrm{R}^{2}$ \\
\hline PN & 4,14 & 0,5492 & 0,8868 \\
PV35 & 9,70 & 0,1557 & 0,5674 \\
PV41 & 8,95 & 0,0836 & 0,6393 \\
PV42 & 9,14 & 0,0683 & 0,6465 \\
GP & 15,11 & 0,2966 & 0,5999 \\
GP35 & 10,26 & 0,1699 & 0,5670 \\
GP41 & 9,36 & 0,0917 & 0,6367 \\
GP42 & 9,57 & 0,0761 & 0,6432 \\
CA & 12,72 & 0,4023 & 0,3845 \\
EF & 12,23 & 0,3500 & 0,3969 \\
PA & 8,97 & 0,0680 & 0,6415 \\
PC & 12,10 & 0,2515 & 0,5933 \\
PEIT & 11,42 & 0,0698 & 0,6088 \\
PPEIT & 4,99 & 0,4906 & 0,6160 \\
CARR & 11,55 & 0,0095 & 0,6001 \\
CARC & 0,0859 & 0,4876 \\
PCARC & 28,61 & 0,1239 & 0,5157 \\
GA & 23,75 & 0,0396 & 0,6377 \\
PGA & 10,39 & 0,1991 & 0,3691 \\
FI & 2,76 & 0,2805 & 0,3649 \\
COR & 13,53 & 0,4964 & 0,5191 \\
PU & 17,00 & 0,0135 & 0,3988 \\
MO & 21,17 & 0,5816 & 0,4408 \\
CI & 11,41 & 0,5750 & 0,3651 \\
\hline - & 7,23 & 0,509 &
\end{tabular}

PN - peso ao nascimento; PV35, PV41, PV42 - peso vivo aos 35, 41 e 42 dias, respectivamente; GP - ganho de peso dos 35 aos 42 dias; GP35, GP41 e GP42 - ganho de peso do nascimento aos 35, 41 e 42 dias, respectivamente; CA - conversão alimentar; EF eficiência alimentar; PA - peso da asa; PC - peso da coxa; PEIT - peso do peito; PPEIT - porcentagem de peito; CARR - peso das costelas; CARC - peso da carcaça; PCARC - porcentagem de carcaça; GA - peso da gordura abdominal; PGA -porcentagem de gordura; FI - peso do figado; COR - peso do coração; PU - peso do pulmão; MO - peso da moela; CI - comprimento do intestino.

** significativo a $\mathrm{P} \leq 0,01 ;$ * significativo a $\mathrm{P} \leq 0,05$ e ${ }^{\dagger}$ significativo a $\mathrm{P} \leq 0,10$. 


\section{REFERÊNCIAS BIBLIOGRÁFICAS}

ALVARES, L.E. Quantificação da expressão dos fatores miogênicos e de Pax-3 durante o desenvolvimento embrionário de aves. Rio Claro, 2001. 132p. Tese (Doutorado) - Instituto de Biociências, Universidade Estadual Paulista “ Julio de Mesquita Filho".

AMILLS, M.; JIMÉNEZ, N.; VILLALBA, D.; TOR, M.; MOLINA, E.; CUBILÓ, D.; MARCOS, C.; FRANCESCH, A.; SÀNCHEZ, A.; ESTANY, J. Identification of three single nucleotide polymorphisms in the chicken insulin-like growth factor 1 and 2 genes and their associations with growth and feeding traits. Poultry Science, v.82, p.1485-1493, 2003.

ANDERSON, L.; HALEY, C.S.; ELLEGREN, H.; KNOTT, S.A; JOHANSSON, M.; ANDERSON, K.; ANDERSON-EKLUND, L.; EDFORS-LILJA, I.; FREDHOLM, M.; HANSSON, I. HAKANSSON, J.; LUNDSTROM, K. Genetic mapping of quantitative trait loci for growth and fatness in pigs. Science, v.263, p.1771-1774, 1994.

ARNOLD, H.H.; BRAUN, T. Genetics of muscle determination and development. Current Topics in Developmental Biology, v.48, p.129-164, 2000.

BLAGDEN, C.S.; HUGHES, S.M. Extrinsic influences on limb muscle organization. Cell Tissue Research, v.296, p.141-150, 1999. 
BOARDMAN, P.E.J.; SANZ-EZQUERRO, I.M.; OVERTON, D.W.; BURT, D.W.; BOSCH, E.; FONG, W.T.; BROWN, W.R.A.; TICLE, S.A; WILSON, S.A.; HUBBARD, S.J. A comprehensive collection of chicken cDNA. Current Biology, v.12, p.1965-1969, 2002.

BORYCKI, A.G.; STRUNK, K.; SAVARY, R.; EMERSON, C.P. JUNIOR - Distinct signal/response mechanisms regulate pax 1 and QmyoD activation in sclerotomal and myotomal lineages of quail somites. Developmental Biology, v.185, p.185-200, 1997.

BOVENHUIS, H.; VAN ARENDONK, J. A. M.; KORVER, S. Associations between milk protein polymorphisms and milk production traits. Journal of Dairy Science, v.75, p.2549-2559, 1992.

BRAND-SABERI, B.; CHRIST, B. Genetic and epigenetic control of muscle development in vertrebates. Review article. Cell Tissue Research, v.296, p.199212, 1999.

BRAUN, T. \& ARNOLD, H.H. Inactivation of myf-6 and myf-5 genes in mice leads to alterations in skeletal muscle development. European Molecular Biology Organization Journal, v.14, p.1176-1186, 1995.

BRAUN, T.; RUDNICKI, M.A.; ARNOLD, H.H.; JAENISCH, R. Target inactivation of the muscle regulatory gene Myf5 results in abnormal rib development and perinatal death. Cell, v.71, p.369-382, 1992.

BRAUN, T.; BUSHHAUSEN-DENKER, G.; BOBER, E.; TANNICH, E.; ARNOLD, H.H. A novel human muscle factor related to but distinct from MyoD1 induces myogenic conversion in $10 \mathrm{~T} 1 / 2$ fibroblasts. European Molecular Biology Organization Journal, v.8, p. 701-709, 1989. 
BRAUN, T.; BOBER, E.; WINTER, B.; ROSENTHAL, N.; ARNOLD, H.H. Myf-6, a new member of the human gene family of myogenic determination factors: evidence for a gene cluster on chromosome 12. European Molecular Biology Organization Journal, v.9, p.821-831, 1990.

BROOKES, A. J. The essence of SNP. Gene, v.234, p.177-186, 1999.

BRYNE, P.F.; MCMULLEN, M.D. Defining genes for agricultural traits: QTL analysis and the candidate gene approach. Probe, v.7, p.24-27, 1996.

BUCKNGHAM, M. Skeletal muscle formation in vertebrates. Current Opinion in Genetics and Development, v.11, p.440-448, 2001.

BUCKINGHAM, M.; BAJARD, L.; CHANG, T.; DAUBAS, P.; HADCHOUEL, J.; MEILLAC, S.; MONTARRAS, D.; ROCANCOURT, D.; RELAIX, F. The formation of sckeletal muscle: from somite to limb. Journal of Anatomy, v.202, p.59-58, 2003.

BUMSTEAD, N.; PALYGA, J. A preliminary linkage map of the chicken genome. Genomics, v.3,p.690-697, 1992.

BURT, D. W. Applications of biotechnology in the poultry industry. World's Poultry Science Journal, v.58, p.5-13, 2002.

CAPDEVILA, J.; IZPISUÁ BELMONTE, J.C. Extracellular modulation of Hedgehog, Wnt and TGF- $\beta$ signalling pathways during embryonic development. Current Opinion in Genetis and Development, v.9, p.427-433, 1999.

CASTELHANO-BARBOSA, E.C. Estudo da expressão espacial e temporal do gene da miostatina durante o desenvolvimento embrinário da galinha (Gallus gallus). Piracicaba, 2001. 78p. Dissertação (Mestrado) - Escola Superior de Agricultura “Luiz de Queiroz”, Universidade de São Paulo. 
CHIRST, B.; ORDAHL,C.P. Early stages of chick somite development. Anatomy and Embriology, v.191, p.381-396, 1995.

CHRIST, B.; BRAND-SABERI, B. Limb muscle development. International Journal of Developmental Biology, v.46, p.905-914, 2002.

CHRIST, B.; JACOB H. J.; JACOB, M. On the origin and development of ventrolateral abdominal muscle in avian embryo. An experimental and ultrastructural study. Anatomy and Embryology, v.186, p.505-510, 1983.

CINNAMON, Y.;KAHANE, N.; BACHELET, I.; KALCHEIM, C. The sub-lip domain - a distinct pathway for myotome precursors that demonstrate rostral-caudal migration. Development, v.128, p.341-351, 2001.

COOPER, D. N.; KARAWCZAK, M. Cytosine methylation and the fate of CpG dinucleotides in vertebrate genomes. Human Genetics, v.83, p.181-188, 1989.

CRITTENDEN, L.; PROVENCHER, L.; SANTANGELO, L.; LEVIN, I.; ABPLANALP, H.; BRILES,R.; BRILES, W.E.; DODGSON, J. Characterization of a Red Jungle Fowl backcross reference population for molecular mappaing of the chicken genome. Poultry Science, v.72, p.334-348, 1993.

DAVIS, R.L.; WEINTRAUB, H.; LASSAR, A.B. Expression of a single transfected cDNA converts fibroblasts to myoblasts. Cell, v.51, p.987-1000, 1987.

DEKKERS, J.C.M.; HOSPITAL, F. The use of molecular genetics in the improvement of agricultura traits. Nature Reviews Genetics, v.3, p.22-32, 2002.

DE VRIES, A.G.; SOSNICKI., A.; GARNIER, J.P.; PLASTOW, G.S. The role of major genes and DNA technology in selection for meat quality in pigs. Meat Science, v.49, p.S245-S255, suppl. 1, 1998. 
DENETCLAW, W.F.JR.; ORDAHL, C.P. The growth of the dermomyotome and formation of early myotome lineages in thoracolumbar somites of chicken embryos. Development, v.127, p.893-905, 2000.

DUNN, I.C.; MIAO, Y.W.; MORRIS, A.; ROMANOV, M.N.; WILSON, P.W.; WADDINGTON, D. A study of association between genetic markers in candidate genes and reproductive traits in one generation of a commercial broiler breeder hen population. Heredity, v.92, p.128-134, 2004

EDMONSON, D.G.; OLSON, E.N. A gene with homology to the myc similarity region of MyoD is expressed during myogenesis and is sufficient to activate the muscle differentiation program. Genes Development, v.3, p. 628-640, 1989.

EMARA, M.G.; KIM, H. Genetic markers and their application in poultry breeding. Poultry Science, v.82, p.952 -957, 2003.

EWING, B.; GREEN, P. Base-calling of automated sequencer traces using Phred II, Error probabilities. Genome Research, v.8, p.186-194, 1998.

FENG, X.P.; KUHNLEIN, U.; AGGREY, S.E.; GAVORA, J.S.; ZADWORNY, D. Trait association of genetic markers in the growth hormone and growth hormone receptor genes in a White Leghorn strain. Poultry Science, v.76, p.1770-1775, 1997.

FUJISAWA-SEHARA, A.; NABESHIMA, Y.; HOSODA, Y.; OBINATA, T.; NABESHIMA, Y. Myogenin contains two domains conserved among myogenic factors. Jounal of Biological Chemistry, v.265, n.25, p.15219-15223, 1990.

FUJISAWA-SEHARA, A.; NABESHIMA, Y.; KOMIYA, T.; UETSUKI, T.; ASAKURA, A.; NABESHIMA, Y. Differential trans-activation of muscle-specific regulatory elements including the mysosin light chain box by chicken MyoD,myogenin, and MRF4. Journal Biological Chemistry, v.267, n.14, p.10031-10038, 1992. 
GEORGES, M. Recent progress in livestock genomics and potential impact on breeding programs. Theriogenology, v.55, p.15-21, 2001.

GILBERT, S.F. Developmental Biology. 7. ed. Sunderland: Sinauer Associates, 2003. $750 \mathrm{p}$.

GORDON, D.; ABAJIAN, C.; GREEN, P. Consed: a graphical tool for sequence finishing. Genome Research, v.8, p.195-202, 1998.

GROBET , L.; ROYO, L.J.; PONCELET, D.; PIROTTIN, D.; BROUWRES, B.; RIQUET, J.; SCHOBERLEIN, A.; DUNNER, S.; MENISSIER, F.; MASSABANDA, J.; FRIES, R.; HANSET, R.; GEORGES, M. A deletion in the bovine myostatin gene causes the double-muscle phenotype in cattle. Nature Genetics, v.17, p.71-74, 1997.

GROENEN, M.A.M.; CROOJMANS, R.P.M.A.; VEENENDAAL, A.; CHENG, H.H.; SIWEK, M.; VAN DER POEL, J.J. A comprehensive microssatelite linkage map of the chicken genome. Genomics, v.49, p.265-274, 1998.

GROENEN, M.A.M.; CHENG, H.H; BUMSTEAD， N.; CRITTENDEN， L.; DODGSON, J.; HILLE, J.; LAMONT, S.; DE LEON, A.P.; SOLLER, M.; TAKAHASHI, H.; VIGNAL,A. A consensus linkage map of the chicken genome. Genome Research, v.10, p.137-147, 2000.

GUSTAFSSON, M.K.; PAN, H.; PINNEY, D.F.; LIU, Y.; LEWANDOWSKI, A. Myf5 is a direct target of long-range Shh signaling and Gli regulation for muscle specification. Genes Development, v.16, p.114-126, 2002.

HAMBURGER, V.; HAMILTON, H. A series of normal stages in the development of chicke embryo. Journal of Morphology, v. 88, p.49-92, 1951. 
HASTY,P.; BRADLEY, A.; MORRIS, J. H.; EDMONDSON, D. G.; VENUTI, J. M.; OLSON, E.; KLEIN, W. H. Muscle deficiency and neonatal death in mice with a target mutation in the myogenin gene. Nature, v.364, p.501-506, 1993.

HILLEL, J. Map-based quantitative trait locus identification. Poultry Science, v. 76, p.1115-1120, 1997.

HUANG, X.; MADAN, A. Cap3: a DNA sequence assembly program. Genome Research, v.9, p.868-877, 1999.

HUTT, F.B. Sex-linked dwarfism in the fowl. Journal of Heredity, v.50, p.209-221, 1959.

IKEOBI, C.O.N; WOOLLIAMS, J.A.; MORRICE, D.R.; LAW, A.; WINDSOR, D.; BURT, D.W.; HOCKING, P.M. Quantitative trait loci affecting fatness in the chicken. Animal Genetics, v.33, p.428-435, 2002.

JI， S.; LOSINSKI， R.L.; CORNELIUS， S.G.; FRANK， G.R.; WILLIS， G.M.; GERRARD, D.E.; DEPREUX, F.F.; SPURLOCK, M.E. Myostatin expression in porcine tissues: tissue specificity and developmental and postnatal regulation. American Journal of Physiology, v.275, p.1265-1273, 1998.

KENNEDY, B. W.; QUINTON, M.; VAN ARENDONK, J. A. M. Estimation of effects of single genes on quantitative trait locus. Journal of Animal Science, v.70, p.2000-2012, 1992.

KRAMER, J.; MALEK, M.; LAMONT, S.J. Association of twelve candidate gene polymorphisms and response to challenge with Salmonella enteritidis in poultry. Animal Genetics, v.34, p.339-348, 2003.

KUHLEIN, U.; PARSANEJAD, R.; ZADWORNY, D.; AGGREY, S.E. The dynamics of the genotype-phenotype association. Poultry Science, v.82, p.876-881, 2003 
KUHNLEIN, U.; NI, L.; WEIGEND, S.; GAVORA, J.S.; FAIRFULL, R.W.; ZADWORNY, D. DNA polymorphism in the chicken growth hormone gene: response to selection for disease resistance and association with egg production. Animal Genetics, v.28, p.116-123, 1997.

LADJALI-MOHAMMEDI, K.; BITGOOD, J.J.; TIXIER-BOICHARD, M.; PONCE DE LEON, F. A. International system for standardized avian karyotypes (ISSAK): standardized banded karyotypes of the domestic fowl (Gallus domesticus). Cytogenetics and Cell Genetics, v.86, p.271-276, 1999.

LANDER, E. S.; BOLTSTEIN, D. Mapping mendelian factors underlying quantitative traits using RFLP linkage maps. Genetics, v. 121, p. 185-199, Jan., 1989.

LEDUR, M.C.; ZANELLA, E.L.; SCHMIDT, G.S.; JAENISCH, F.R.F.; SAATKAMP, M.G.; BASSI, L.J.; COUTINHO, L.L. Peso e características de carcaça em linhagens utilizadas no desenvolvimento de populações referência para detecção de QTL em aves. Revista Brasileira de Ciência Avícola, suppl. 2, p.73, 2000.

LINVILLE, R.C.; POMP, D.; JOHNSON, R.K.; ROTHSCHILD, M.F. Candidate gene analysis for loci affecting litter size ond ovulation rate in swine. Journal of Animal Science, v.79, p.60-67, 2001.

LUDOLPH, D.C.; KONIECZNY, S.F. Transcription factors families: muscling in on the myogenic program. FASEB Journal, v.9, p.1595-1604, 1995.

MACKAY, T.F. The genetic architecture of quantitative traits. Annual Reviews of Genetics, v.35, p.303-339, 2001

MALEK, M.; LAMONT, S.J. Association of INOS, TRAIL, TGF- $\beta$, TGF- $\beta 3$, and IgL genes with response to Salmonella enteritidis in poultry. Genetic Selection and Evolution, v.35, suppl.1, p.S99-S111, 2003. 
MALEK, M.; HASENSTEIN, J.R.; LAMONT, S.J. Analysis of chicken TLR4, CD28, MIF, MD-2, and LITAF genes in a Salmonella enteritidis resorce population. Poultry Science, v.83, p.544-549, 2004.

MCPHERRON, A.C.; LEE, S.-J. Double muscling in cattle due to mutations in the myostatin gene. Proceedings of National Academy of Science of the USA, v.94, p.12457-12461, 1997.

MCPHERRON, A.C.; LAWLER; A.M., LEE, S.-J. Regulation of skeletal muscle mas in mice by a new TGF- $\beta$ superfamily member. Nature, v.387, p.83-90, 1997.

MEGENEY, L.A.; KABLAR, B.; GARRET, K.; ANDERSON, J.E.; RUDNICKI, M.A. MyoD is required for myogenic stem cell function in adult skeletal muscle. Genes Development, v.10, p.1173-1183, 1996.

MINER, J.H.; WOLD, B. Herculin, a fourth member of the MyoD family of myogenic regulatory genes. Proceedings of National Academy of Science of the USA, v.87, p.1089-1093, 1990.

MORAN, C. Microsatellite repeats in pig (Sus domestica) and chicken (Gallus domesticus) genomes. Journal of Heredity, v.84, n.4, p.274-280, 1993.

MORRISSON, M.; PITEL, F.; FILLON, V.; POUZADOUX,A.; BERGE, R.; ZOOROB, R.; AUFFRAY, C.; GELLIN, J.; VIGNAL, A. Integration of chicken cytogenetic and genetic maps: 18 new polymorphic markers isolated from $\mathrm{BAC}$ and PAC clones. Animal Genetics, v.29, p.348-355, 1998.

MOTT, I.; IVARIE, R. Expression of myostatin is not altered in lines of poultry exhibinting myofiber hyper- and hypoplasia. Poultry Science, v.81, p.799-804, 2002. 
NABESHIMA, Y.; HANAOKA, K.; HAYASAKA, M.; ESUMI, E.; LI, S. NANOKA, I.; NABESHIMA, Y. Myogenin gene disruption results in perinatal lethality because of severe muscle defect. Nature, v.364, p.532-535, 1993.

NAGARAJA, S.C.; AGGREY, S.E.; YAO, J.; ZADWORNY, D.; FAIRFULL, R.W.; KUHNLEIN, U. Trait association of a genetic marker near the IGF-I gene in egglaying chickens. The Journal of Heredity, v.91, n.2, p.150-156, 2000.

OLSON, E.N. MyoD family: a paradigm for development. Genes and Development, v.4, p.1454, 1990.

OLSON E.N., PERRY M.; SCHULZ R.A. Regulation of muscle differentiation by the MEF2 family of MADS box transcription factors. Developmental Biology, v.172, p.2-14, 1995.

PATAPOUTIAN, A.; YOON, J.K.; MINER, J.H.; WANG, S.; STARK, K.; WOLD, B. Disruption of the mouse MRF4 gene identifies multiple waves of myogenesis in the myotome. Development, v.121, n.10, p.3347-3358, 1995.

PERRY, R.S.; RUDNICK, M.A. Molecular mechanism regulating myogenic determination and differentiation. Science, v.5, p.d750-d767, 2000.

PICARD, B.; LEFAUCHEUR, L.; BERRI, C.; DUCLOS, M.J. Muscle fibre ontogenesis in farm animal species. Reproduction Nutrition and Development, v.42, p.415-431, 2002.

PORQUIÉ, O. Vertebrate Somitogenesis. Annual Reviews Cell of Developmental Biology, v.17, p.311-350, 2001.

POULTRY GENOME NEWSLETTER. Draft chicken genome sequence released, abril, n.2, p.1-4, 2004. 
POWNALL, M.E.; GUSTAFSSON, M.K.; EMERSON, C.P.JUNIOR. Myogenic regulatory factors and the specification of muscle progenitors in vertebrate embryos. Annual Reviews of Cell Developmental Biology, v.18, p.747-783, 2002.

PURI, P.L.; SARTORELLI, V. Regulation of muscle regulatory factors by DNAbinding, interacting proteins and post-transcriptional modification. Journal of Cellular Physiology, v.185, p.155-173, 2000.

REHFELDT, C.; FIEDLER, I.; DIETL, G.; ENDER, K. Myogenesis and postnatal skeletal muscle cell growth as influenced by selection. Livestock Production Science, v.66, p.177-188, 2000.

RHODES, S.; KONIECZNY, S.F. Identification of MRF4: a new member of the muscle regulatory factor gene family. Genes Development, v.3, p.2050-2061, 1989.

ROTHSCHILD, M.F.; SOLLER, M. Candidate gene analysis to detect genes controlling of economic importance in domestic livestock. In: SIMPÓSIO INTERNACIONAL DE GENÉTICA E MELHORAMENTO ANIMAL, Viçosa MG. Anais. Viçosa: UFV, 1999. p.219-242.

RUDNICKI, M.A.; BRAUN, T.; HINUMA, S.; JAENISCH, R. Inactivation of MyoD in mice leads to up-regulation of the myogenic HLH gene Myf5 and results in apparently normal muscle developments. Cell, v.71, p.383-390, 1992.

RUDNICKI, M.A.; SCHNEGELSBERG, P.N.J.;STEAD,R.H.; BRAUN,T.; ARNOLD, H.H.;JAENISCH, R. MyoD or Myf5 is required in a functionally redundant manner for the formation of skeletal muscle. Cell, v.75, p.1351-1359, 1993.

SABOURIN, L.A.; RUDNICKI, M.A. The molecular regulation of myogenesis. Clinical Genetics, v.57, p.16-25, 2000. 
SANGER, F.; NICKLEN, S.; COULSON, A.R. DNA sequencing with chainterminating inhibitors. Proceedings of the National Academy of Sciences of United States of America, v. 4, n.12, p.5463-55467, 1977.

SAS INSTITUTE. SAS user's guide: Statistics. Cary,. p.955, 1997

SHARMA, M.; KAMBADUR, R.; MATTHEWS, K.J. Myostatin, a transforming growth factor-b superfamily member, is expressed in heart muscle and is upregulated in cardiomycetes after infarct. Journal of Cell Physiology, v.180, p.1-9, 1999.

SHORT, T. H.; ROTHSCHILD, M. F.; SOUTHWOOD, O. I.; MCLAREN, D. G.; DE VRIES, A.; VAN DER STEEN, H.; ECKARDT, G. R.; TUGGLE, C. K.; HELM, J.; VASKE, D. A.; MILEHAM, A. J.; PLASTOW, G.S. Effect of the estrogen receptor locus on reproduction and production traits in four commercial pig lines. Journal of Animal Science, v.75, n.12, p.3138-3142, 1997.

SMITH, J.; PATON, I.R.; BRULEY, C.K.; WINDSOR, D.; BURKE, D.; PONCE DE LEON, F.A. Integration of genetic and physical maps of the chicken macrochromosomes. Animal Genetics, v.31, p.20-27, 2000.

SOURDIOUX, M.; BREVELET, C.; DELABROSSE, Y.; DOUAIRE, M. Association of fatty acid synthase gene and malic enzyme gene polymorphisms with fatness in turkeys. Poultry Science, v.78, p.651-1657, 1999.

STOCKDALE, F. S.; NIKOVITS, W. JUNIOR.; CHRIST, B. Molecular and cellular biology of avian somite development. Developmental Dynamics, v.219, p.304-321, 2000.

TAJBAKHSH, S.; BOBER, E.; BABINET, C.; POURNIN, S; ARNOLD, H.; BUCKINGHAM, M. Gene targeting the myf-5 locus with nlacZ reveals expression of this myogenic factor in mature skeletal muscle fibres as well as early embryonic muscle. Developmetal Dynamics, v.206,n.3, p.291-300, 1996a. 
TAJBAKHSH, S.; ROCANCOURT, D.; BUCKINGHAM, M. Muscle progenitor cells failing to respond to positional cues adopt non-myogenic fates in myf-5 null mice. Nature, v.384, n.6606, p.266-70, 1996 b.

TAYLOR, S.M.; JONES, P.A. Multiple new phenotypes induced in 10T 1/2 and 3T3 cells treated with 5-azacytidine. Cell, v.17, p.771-779, 1979.

TE PAS, M.F.W. Candidate genes for meat quality - the MRF genes. Animal Science and Reports, v.22, n.1, p.115-118, 2004.

TE PAS, M.F.W.; SOUMILLION, A.; HARDERS, F.L.; VERBURG, F.J.; VAN DEN BOSCH, T.J. GALESLOOT, P.; MEUWISSEN, T.H.E. Influences of myogenin genotype on birth weight, growth rate, carcass weight, backfat thickness and lean weight of pigs. Journal of Animal Science, v.77, p. 2352-2356, 1999.

THOMAS, M.; LANGLEY, B.; BERRY, C.; SHARMA, M.; KIRK, S.; BASS, J.; KAMBADUR, R. Myostatin, a negative regulator of muscle growth, functions by inhibiting myoblast proliferation. The Journal of Biological Chemistry, v.275, p.40235-40243, 2000.

TIXIER-BOICHARD, M. From phenotype to genotype: major genes in poultry. World's Poultry Science Journal, v.58, n.1, p.65-75, 2002.

TOBITA-TERAMOTO, T.; JANG, G.Y.; KINO, K; SALTER, D.W.; BRUMBAUGH, J.; AKIYAMA, T. Autossomal albino chicken mutation (ca/ca) detetes hexanucleotides (-GACTGG817) at copperbinding site of tyrosinase gene. Poultry Science, v. 78, p.46-50, 2000.

VIGNAL, A. Genomics and the genetic improvement of broiler chicken. Outlook on Agriculture, v.33, n.2, p.79-84, 2004. 
VIGNAL, A.; MILAN, D.; SANCRISTOBAL, M.; EGGEN, A. A review on SNP and other types of molecular markers and their use in animal genetics. Genetics Selection Evolution, v.34, p.275-305, 2002.

VINCENT, A.L.; EVANS, G.; SHORT, T.H.; SOUTHWOOD, O.I.; PLASTOW, G.S.; TOGGLE, C.K.; ROTHSCHILD, M.F. The prolactin receptor gene is associated with increased litter size in pigs. In: WORLD CONGRESS ON GENETICS APPLIED TO. LIVESTOCK. PRODUCTION, 6., Armidale, 1998. Proceedings. Armidale: NSW, 1998. v.27, p.15-18.

WEIGEND, S.; ROMANOV, M.N. Current strategies for assessment and evaluation of genetic diversity in chicken resources. World's Poultry Science Journal, v.57, p.275-288, 2001.

WEINTRAUB, H.; DAVIS, R.; TAPSCOTT, S.; THAYER, M.; KRAUSE, M.; BENEZRA, R.; BLACKWELL, T.K.; TURNER, D.; RUPP, R.; HOLLENBERG, S.; ZHUANG, Y.; LASSAR, A. The myoD gene family: nodal point during specification of the muscle cell lineage. Science, v.251, p.761-766, 1991.

WRIGHT, W.E.; SASSOON, D.A., LIN, V.K. Myogenin, a factor regulating myogenesis, has a domain homologous to MyoD. Cell, v.56, p.607-617, 1989.

ZHILIANG, G.; ZHU,D.; LI, N.; LI, H.; DENG, X.; WU, C. The single nucleotide polymorphisms of the chicken myostatin gene are associated with skeletal muscle and adipose growth. Science in China Series C-life Sciences, v.47, n.1, p.25-30, 2004. 